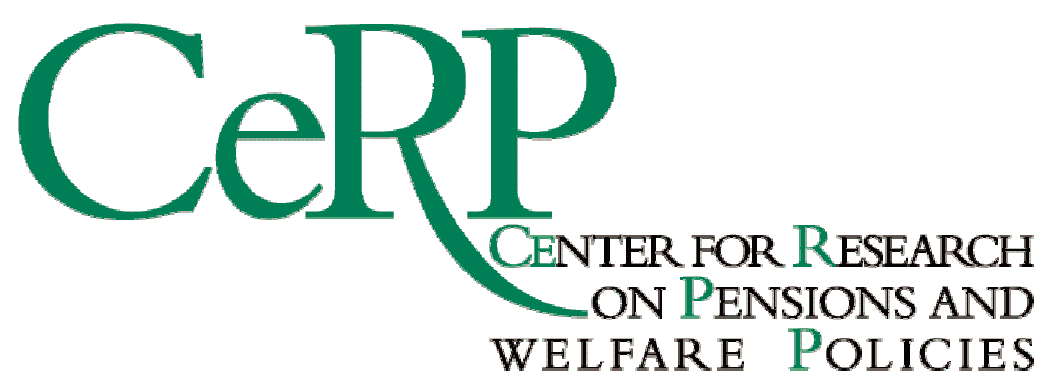

Working Paper 16/01

\title{
ANNUITIES MARKETS AROUND THE WORLD: MONEY'S WORTH AND RISK INTERMEDIATION
}

Estelle James, Consultant, World Bank

Xue Song, Institute for Women's Policy Research 


\title{
Annuities Markets Around the World: Money's Worth and Risk Intermediation
}

\author{
By \\ Estelle James, Consultant, World Bank* \\ Xue Song, Institute for Women's Policy Research
}

This is a revised and greatly expanded version of papers prepared for presentation at the American Economic Association meetings, January 2001 and the World Bank Pension Research Conference, September 1999. The World Bank and AEA papers were co-authored by Dimitri Vittas. Work on this paper was carried out while Estelle James was a Visiting Fellow at CeRP (Center for Research on Pensions and Welfare Policies), Turin, Italy. We wish to thank industry representatives, including Mark Hug (Equitable), Alex Scheitlin (Metlife), Michael Koller and Fred Siegrist (Swiss life), Tim Pfeiffer (insurance industry consultant), Shane Chalke (AnnuityNet), Nick Bauer (Eckler Partners, Montreal), D'Alton S. Rudd (formerly Pension Commission of Ontario), Juan Carlos Padilla (Hewitt Associates, Mexico) and Peter Foo (NTUC Income, Singapore) for their helpful comments and insights. Thanks also to Chris Daykin (Government Actuary's Department, UK), J. Michael Orszag (Birkbeck College, UK), Rob Brown (University of Waterloo, Canada), Martin Janssen (University of Zurich), Mukul Asher (National University of Singapore), Rahul Sen (National University of Singapore), Augusto Iglesias (Primamerica, Chile), Jeffrey Brown (Harvard University) and Don McIsaac (World Bank) for their assistance. And to all the participants in the World Bank Annuity Research Project for their country reports (see endnote 1).

* Correspondence about this paper should be directed to Estelle James, ejames@estellejames.com http://www.estellejames.com/ 


\section{Abstract: Annuities Markets Around the World: Money's Worth and Risk Intermediation}

Annuities markets around the world are small. However, they have been growing in recent years and are likely to grow further as a result of reforms in public social security systems and private pension plans, that partially replace defined benefit plans with funded defined contribution plans. When people retire they may choose, and are sometimes required, to annuitize these defined contribution savings. Therefore, it is important to learn whether or not annuities markets exist, how they operate and what kinds of market failure can be anticipated. Several papers have already analyzed US annuities markets. This paper extends that analysis by examining annuities markets in other countries. We present evidence from Canada, the UK, Switzerland, Australia, Israel, Chile and Singapore - a variety of high and middle-income countries - and replicate the results from the US.

This paper focuses on analyses of the expected present discounted value (EPDV) of cash flows from the annuity, and the money's worth ratio (MWR), which is the EPDV divided by the initial premium cost. We find that, when discounting at the risk-free rate, MWR's for annuitants are surprisingly high--greater than $95 \%$ in most countries and sometimes greater than $100 \%$. MWR's for the average population member are lower but still exceed $90 \%$ in most cases. We show that differential interest rate structures largely explain differential monthly payouts across countries, while differential mortality rates, especially projected improvement factors, help explain differences in measured MWR's, given these monthly payouts and interest rates.

The high MWR's raise the question: How do insurance companies cover their costs despite these high MWR's? We hypothesize that for each annuity sale, insurance companies get a large sum of money up-front that they invest in a portfolio of corporate bonds, mortgages, and some equities, earning a rate of return that exceeds the risk-free rate by $1.3 \%$ or more per year. They turn this "risky" portfolio into a safer annuity by a variety of risk-intermediation, term-intermediation techniques. This allows them to sell a product that is nearly risk-free, while earning a "spread" that covers their costs. We present data on cost and investment returns that are consistent with this hypothesis. The limited opportunity to earn this spread may help explain why price indexed annuities in the UK charge higher loads to cover their costs and risks. For consumers who would prefer to accept this investment risk and capture this spread themselves, the appropriate discount rate is higher and the MWR is lower, helping to explain the low demand for annuities in voluntary markets. 


\section{Annuities Markets Around the World: Money's Worth and Risk Intermediation}

Structural reforms of social security and pension systems, that incorporate funded individual accounts, have been taking place around the world during the past two decades. Most of the attention thus far has focused on the accumulation phase, during which mandatory retirement savings accounts are being built up. But ultimately retirement savings will be withdrawn and consumed. So in the second generation of reforms countries have begun paying attention to decumulation. Annuitization is often encouraged and in some cases required in the new mandatory systems - an increasing number of workers are likely to take this route toward decumulation. At this point, it becomes important to learn whether or not annuities markets exist, how they operate and what kinds of market failure can be anticipated. In the U.S., where social security reform including individual accounts is already on the political agenda, similar questions will arise. Several papers have already analyzed US annuity markets, including analyses of money's worth, adverse selection and redistributional effects. (For example, see Mitchell, Poterba, Warshawsky and Brown 1999, Brown Mitchell and Poterba 2000, Poterba and Warshawsky 1999, Brown 2000).

This paper extends that analysis by examining annuities markets in other countries. We present evidence from Canada, the UK, Switzerland, Australia, Israel, Chile and Singapore - a variety of high and middle-income countries - and replicate the results from

the US. This sample is clearly too small for econometric testing, but it yields some interesting insights. We explore whether and why the monthly payouts and "money's worth ratios" (MWR's) differ across countries and how insurance companies cover their costs in countries if the MWR's are high.

The MWR is the ratio of expected discounted lifetime benefits to initial capital cost of the annuity. We focus on annuities that provide longevity insurance. While we structure this paper as a search by analysts for the MWR, insurance companies, consumers, regulators and policy-makers must carry out the same search for their own reasons. Companies must figure out how large are the payouts they can offer, consumers must calculate the expected value to them of alternative annuity products (versus no annuitization 
at all), regulators must ensure that the system as a whole is solvent and policy-makers must understand the industry in order to set the rules of the game.

Annuities markets are still poorly developed in virtually all these countries. The underdevelopment of the industry manifests itself in: its small size relative to other kinds of insurance, the absence of mortality tables which are a prerequisite to sound pricing and funding policies, and the relative paucity of long term financial instruments with which to match assets and liabilities, thereby creating substantial reinvestment risk. Given the underdevelopment of annuity markets we might expect to find random variations in payouts and low money's worth ratios, implying high costs for consumers. However, as reported in an earlier paper, we found surprisingly high MWR's in a variety of countries (James and Vittas 1999b). ${ }^{\text {[n }}$ Inis paper we re-examine these results and examine their plausibility in four ways: we 1) refine and improve the data; 2) analyze the degree to which interest rate or mortality differentials are responsible for differences across countries in monthly and expected lifetime payouts; 3) examine costs of providing annuities, and how insurance companies cover their costs if the MWR is high; and 4) address the questions - why do firms supply annuities (and why don't consumers buy annuities) in view of their high MWR's?

Our data indicate that monthly annuity payouts vary widely across countries, but the variation is systematic and the MWR's are much less dispersed. We show that differential interest rates, which vary widely across countries, largely explain the differential monthly payouts and are set to equalize expected discounted lifetime payouts for a common mortality structure. In contrast, differential mortality rates, especially projected improvement factors, help explain the smaller differences in measured MWR's, given these monthly payouts and interest rates. As before, we find that, when discounting at the riskfree treasury rate, these payouts yield money's worth ratios for the average annuitant that exceed $95 \%$ in almost every case - and sometimes even exceed 100\%. Annuitants get back, in expected present value, almost exactly what they put in and sometimes more. For the average member of the population (who has a shorter life expectancy than the average annuitant) the MWR exceeds $90 \%$ in most countries. ${ }^{\text {B }}$ If workers had the objective of smoothing consumption over their life cycle, one would expect a higher level of annuitization, given these MWR's. Later we return to this issue. 
Where do insurance companies get the money to cover their administrative costs, risk premium and profits, in view of these seemingly high MWR's? Some analysts have defined administrative costs as the difference between $100 \%$ of premiums and the MWRthe share that is returned to annuitants. Our more direct measurements indicate that the present value of administrative expenses (including marketing and operational costs) over the lifetime of an average annuity is about $7-8 \%$ of the premium. Additionally, companies bear reinvestment and longevity improvement risk and incur an opportunity cost of equity capital, which bring total costs, capitalized, to $10-12 \%$ of initial premiums, or $1.2-1.5 \%$ of assets per year.

We hypothesize that in the annuities market, the insurance company acts as an institution for risk and term intermediation and earns a spread in the process. The annuitant pays a large sum of money up-front in exchange for a guarantee of fixed periodic payments at a price that is actuarially fair at the risk-free discount rate. The company takes the premium paid up-front and invests (mainly in long term public and private bonds and mortgages but also in some equities) to earn an uncertain return with a higher expected value. The insurance company then retains the residual or "spread" between the actual risky return and the guaranteed payout. Our data on investment portfolios and returns of insurance companies (buttressed by discussions with industry executives from several countries) demonstrate that the spread usually exceeds $1.3-2 \%$ of assets per year. The supply behavior of insurance companies suggests that this spread is ample cover their administrative costs, risk and profits.

Part I presents capsule summaries of annuities markets and pension systems that impact the annuities markets in each of our 8 sample countries. The markets in the US and Canada are voluntary. In the other countries the annuities markets are part of their mandatory social security systems. In Israel and Switzerland we compare the voluntary and quasi-mandatory markets that co-exist. Part II sets forth our data on payouts of different annuity products. Parts III and IV analyze the money's worth ratios, including the sources of differences across countries in payouts and MWR's. Part V presents cost data and expense ratios. Part VI outlines investment portfolios of life insurance companies and imputes the returns. The Conclusion raises some questions about the future development of the annuity industry. 


\section{The Annuities Market in Sample Countries}

The annuities market depends in large part upon the nature of the mandatory social security system in a country. Most countries of our sample initially had defined benefit payas-you-go social security systems, but during the past twenty years funded personal (defined contribution) accounts have become mandatory or important options in all our sample countries except for Canada and the US. Upon retirement some form of gradual withdrawal is required, and annuitization is usually one of the few acceptable forms. Governments often place restrictions on the type or price of annuities that may be purchased within the mandatory system, which influence the way the market will develop. Therefore we start out with thumbnail sketches of these systems and how they are changing.

Even in countries that have introduced personal accounts as part of their mandatory social security systems, the new systems are far from mature. It takes 60 years to generate a mature system - a full complement (i.e. about 20 cohorts) of retirees, each contributing to the accounts for a full working life (i.e. about 40 years). Until full maturity is reached, the potential annuities market increases in size each year. So far only Chile, Switzerland, the UK and Singapore have had their defined contribution accounts, with annuitization as an encouraged option for withdrawal, for more than ten years, and only Chile for more than 20 years. We are therefore observing at this point only the beginnings of the potential growth of the annuities market and the collection of data on annuitants.

Data on the current size and recent growth of annuities markets, compared with total life insurance markets, are presented in Table 1 and more detailed data for Chile in Table 2. These data show that annuity markets are growing, but the nature of this growth is largely dictated by incentives and constraints set by public policy. In Chile we observe the most rapid growth of annuities with longevity insurance, because of regulatory constraints on the ways in which mandatory retirement savings can be disbursed and incentives to retire early by annuitizing. In contrast, in Canada, the US and Australia, where tax advantages encourage saving in "variable annuities", most "annuity" products are still in the accumulation stage and may never become payout annuities that offer longevity insurance. 
UK. Until 1978 the UK had only a flat basic benefit in its public system (or first pillar). The flat benefit was virtually universal but small—currently it is only about $16 \%$ of the average wage. Many workers depended on employer-sponsored defined benefit pensions, often collectively bargained, for their retirement income. In 1978 the UK added a state earnings-related component (SERPS) to the public system but allowed employers to opt out if they offered their own pension plans that met specified standards. Small employers sometimes used insurance companies to handle these pensions, so a pensionannuity business developed. Still a further development occurred in 1988 when individual workers were allowed to opt out of SERPS or their employer's plan into their own personal saving plan.

At present the majority of workers, particularly middle and high earners, are in employer plans or their own personal plans, that is, in privately managed plans, rather than SERPS. In contrast, most low income workers (about a quarter of the total labor force) remain in SERPS. This public-private mix is the UK's "second pillar" (Pillar II) of retirement security. For workers who opt out of SERPS, part of their social insurance contribution (about $4-9 \%$ of wages, depending on age) is rebated to their accounts; additional amounts may also be contributed on a voluntary basis. Workers are required to annuitize the rebated portion at some point between the age of 65 and 75 . Workers can also take their money out of their employer-sponsored plan and annuitize in the open market. Thus the annuity market is a growth industry in the UK.

In addition to this market that is part of the compulsory system, workers can purchase annuities out of their voluntary savings (the "third pillar), but these amounts are relatively small-less than $20 \%$ of the total. By 1997, annual premiums paid in the voluntary and compulsory parts of the market together were almost 5 billion pounds (US\$7.5 billion), having grown over 50\% during the 1990's and expected to grow substantially in the future (Murthi, Orszag and Orszag 1999). In this paper we analyze data from a mix of these two markets - since they are not firmly separated - but the compulsory part dominates. ${ }^{\text {G }}$

Switzerland. Switzerland offers a modest public benefit (Pillar I) that depends on wages and years of work. A compressed progressive formula pays a high replacement rate to low earners. This is supplemented by employer-sponsored plans that covered about half 
of the labor force on a voluntary or collectively bargained basis during the 1970's and early 1980's but, since 1985, have become mandatory for all workers except low earners (Pillar II). The second pillar provides a high replacement rate to middle and high earners. Annual contributions to the second pillar range between 12 and $15 \%$ of wages. Upon retirement, this accumulation is usually annuitized, in a form and at a price tightly regulated by the government. The annuity is often provided by an insurance company chosen by the pension fund or employer. Lump sum withdrawals are also permitted, but tax incentives as well as favorable terms strongly encourage annuitization.

Workers who desire additional annuitization can purchase it in the purely voluntary market (Pillar III). However, the voluntary market is very small in Switzerland, as in the UK. We analyze both the voluntary and mandatory markets in this paper. These two markets are separated, due to tight restrictions over Pillar II. In 1996 premiums paid into the Pillar III market, mostly for immediate annuities, totaled SF 2.3billion (US\$1.5 billion), while contributions into Pillar II, largely during the accumulation stage, totaled \$SF27 billion (US\$18 billion) (Breuer and Zweifel 1999).

Australia. Australia, like the UK, has long offered a flat benefit to the old. In Australia this benefit is broad-based but means- and asset-tested; it goes to $70 \%$ of the older population. The means-testing allows it to be higher than the level in the UK--25\% of the average wage for an individual, $40 \%$ for a couple. As in the UK and Switzerland, this has long been supplemented by collectively bargained pension plans that covered much of the labor force. Concerned about the aging of the population and the increasing fiscal burden this would imply, and desiring to increase worke compensation without generating inflationary pressures, in 1992 the government made these employer-sponsored plans mandatory-Australia's superannuation system. Most take the form of defined contribution plans, with the contribution rate starting at $4 \%$ but scheduled to reach $9 \%$ (and remain there) by 2002. All but the lowest earners are covered.

The Australian system is still very immature and very much in the accumulation rather than the payout phase. Annuitization is one of the options for drawing down these accounts upon retirement, but annuities are not required or strongly encouraged, nor does the government constrain the form of the annuity as it does in the UK or Switzerland. Australia therefore will permit us to examine the situation where retirement savings are 
accumulated but the manner of withdrawal is left to the worker's discretion. Interestingly, "allocated annuities" where workers choose the investment strategy and take scheduled withdrawals over a fixed time period, are most popular and "life annuities" that provide longevity insurance but give annuitants little or no control over investment strategy are least popular. Out of total assets backing annuities in 1998, only $38 \%$ were in the payout stage and, of these, only $32 \%$ were life annuities. In this paper we do not distinguish between the mandatory and voluntary parts of the market, but most of current demand and expected future growth comes from the mandatory scheme.

Singapore. Unlike other countries in this study, Singapore has no public cash benefit (Pillar I) for the old, although it provides a variety of means-tested subsidized services for both old and young - subsidized housing, medical care and the like. The basis for retirement income in Singapore is the defined contribution (Pillar II) that has been made each year, since 1955, to the Central Provident Fund. The contribution rate is currently 35\% although it has been $40 \%$ in the past and is expected to rise again in the future. The money is turned over the Singapore's Monetary Authority to invest and CPF members receive, in return, an interest rate that, for many years, has been approximately $2 \%$ above the rate of inflation. This contribution is used to finance many services besides old age security-medical insurance and most important, loans for home ownership. As a result, relatively little money has been left in the accounts when workers retire.

Concerned about this situation, in 1987 the Singapore government instituted the Minimum Sum Scheme: At the age of 55 workers must set aside $\$ 55,000$ (now $\$ 65,000$ and rising gradually to $\$ 80,000$ ) to 1) buy a deferred life annuity payable at age 62,2 ) deposit with a bank or 3) leave with the Central Provident Fund and take out in gradual withdrawals. As a result of this Scheme, the annuity business is now growing rapidly in Singapore-more rapidly than in other countries since workers had already been accumulating funds in their accounts for many years. While annuity policies in force are only a tiny fraction of life policies business in force, new annuities are now 13\% of new insurance premiums. We analyze the annuity industry that is newly emerging as a result of the Minimum Sum Scheme. Two large insurance companies occupy more than two-thirds of the market, the dominant one being the National Trade Union Income Company, which is run by the largest trade union in Singapore. The most popular type of annuity is the 
"participating" annuity that gives the company substantial discretion in passing on mortality and investment risk and return.

Chile. In Chile the annuity market is the largest of all the countries in our sample (relative to GDP), due to the new pension system that started in 1981 and is therefore mature enough to have many retirees. This system features a defined contribution of $10 \%$ in Pillar II, reaching 13\% when administrative costs and survivors and disability insurance are added. The first pillar is very small — a minimum pension guarantee targeted toward low earners with small accumulations. When they retire, workers in Chile are permitted to 1) leave their retirement savings in their pension funds and take programmed withdrawals, 2) take an immediate annuity, or 3) take a deferred annuity with programmed withdrawals in the interim. Incentives and constraints in the system largely shape which choice workers make.

The experience of Chile illustrates how the detailed rules of the system determine the growth path of the annuity market. Two factors enabled the annuity market to get off to an early start, even before the new pension system matured: 1) Workers who switched into the new pension system received a "bono"--a compensation bond for their work under the previous system - which could be cashed upon retirement and applied toward the purchase of an annuity, thereby enlarging the size of the annuity; and 2) Disability and survivors insurance were provided through the private market, in exchange for a required annual premium, as part of the pension reform. The earliest growth of the annuity market, during the first decade, came from workers who became disabled and those who cashed in their bonos upon normal retirement.

However, the largest growth, in the second decade, came from regulations that allow workers to retire early if they had enough savings to purchase an annuity that exceeds $110 \%$ of the minimum pension (i.e. about $27 \%$ of the average wage in the economy) and also exceeds $50 \%$ of own average wage over the last 10 years. Early retirement means simply that a worker can stop contributing to the mandatory system and start drawing out money, while continuing to work if he chooses to do so. Moreover, if the annuity exceeds $70 \%$ of his average wage, the rest can be taken out as a lump sum - he gets immediate access to much of his retirement savings. Starting in 1987, workers were permitted to apply their recognition bonds toward an early retirement pension; in 1990 these bonds were made 
tradeable; and in 1994 pension funds were authorized to buy recognition bonds. Enterprising insurance companies seized upon this opportunity to entice customers into the market. They approached workers who were close to eligibility for early retirement (a large group as the annual rate of return on pension funds exceeded 10\% real during the 1980's and 1990's) and offered to facilitate the process. They handled the paper work to maximize the size of the lump sum withdrawal, bought the worker's "bono" early at a discount and lent him money to deposit in his account, to help him meet the criteria. Additional (unofficial) incentives were provided by salesmen who shared part of their commissions with the annuitant. (If the insurance company gave a large commission to the salesman, knowing it would be shared, this was another way to provide a lump sum to the worker).

As a result of these incentives, the annuity business has grown dramatically in Chile. Its reserves have risen from US\$1.5 billion in 1988 to $\$ 7.7$ billion in 1998 and are expected to reach $\$ 37$ billion in 2010. Total premiums now exceed US\$1 billion per year. Annuitants rose from less than $10 \%$ of all beneficiaries in 1988 to over $50 \%$ in 2000 (Tables $2 \mathrm{~A}$ and $2 \mathrm{C}$ ), as early retirement beneficiaries rose from $1 \%$ to over a third of all recipients, accounting for over half of all payouts (Table 2B). Annuity premiums are now twice as large as life insurance premiums (Table 1). And most of these are early retirement annuities with longevity insurance. While annuitization is commonly associated with a desire to smooth consumption over the remaining lifetime, under these conditions it has become a mechanism for getting access to retirement savings sooner rather than later.

Regulations have also shaped which groups buy annuities. Chilean workers have a choice between annuities, gradual withdrawals, and a combination of temporary withdrawals plus deferred annuity. By 2000 more than half of all recipients and even more of the payouts were in the form of annuities. However, a closer examination shows that few workers faced a level playing field and the playing field differed systematically by type of benefit and socio-economic group.

Early retirees were the wealthiest group (as evidenced by the fact that they had the highest annual payouts which far exceeded the minimum pension; see Table 2A). Among early retirees the vast majority —about 85\%--purchased annuities in 2000. Initially annuity purchase was required to meet the eligibility criteria. Later workers were allowed to qualify on the basis of gradual withdrawals. But insurance companies still had a big advantage 
owing to their ability to buy the bonos, lend money and handle the paperwork that would enable workers to qualify and get large lump sums; these are real services given the rules of the game in Chile. Only those with the highest earnings and savings (hence the largest payouts) could accomplish this and retire early without the help of an insurance company. Unconstrained choice would probably have led to a lower level of annuitization among early retirees.

In contrast, among those retiring at normal old age only one-third purchase annuities, and this tends to be the better-off group, as evidenced by their higher average payouts among the normal retirees. The remaining two-thirds consist of three sub-groups: those who prefer a variable to a fixed return, those who are already receiving pensions from the old system, and, especially, those whose retirement savings are not large enough to purchase a minimum pension (low earners). The latter sub-group must take gradual withdrawals until their savings are exhausted, whereupon the government steps in to pay the minimum pension. Thus, the lowest earners are largely excluded from the annuities market by social security system rules, in Chile as in most other countries in our sample. The excluded proportion will decline as the system matures so retiring workers have longer years of contributions and larger accounts and do not have pensions from the old system. Unconstrained choice in the long run would probably lead to a higher level of annuitization among normal retirees.

Among the disabled and survivors, one-third choose annuitization. Our data on payouts and money's worth ratios, based on retirement at age 65, are primarily for the old age (early and normal retirement) market.

Israel. Israel has a small but very complex annuity market, including a voluntary and quasi-mandatory part. The public benefit in Israel (Pillar I) is a universal flat benefit, about $25 \%$ of the average wage, paid to every resident over the age of 65 . Supplementing this were defined benefit pension arrangements that were put in place many years ago by labor unions, heavily subsidized by government, covering about half of the labor force (in general, the upper half) — which we call "quasi-compulsory". The subsidy took the form of special non-tradeable government bonds, in which the funds were fully invested, that paid an above-market interest rate. Despite the subsidy, however, the accumulated reserves were 
not large enough to pay the promised benefits, which became a contingent liability of the government.

Concerned about this growing fiscal burden, in 1997 the government negotiated a new arrangement which downsized its obligation: The subsidy on government bonds was reduced, the bonds would cover only $70 \%$ of the pension funds' investments, and benefits were changed to age-specific deferred non-guaranteed annuities that were required to be adjusted frequently to remain actuarially sound. Each year, out of the $16 \%$ contribution rate, disability and survivors insurance is purchased, as well as a deferred old age annuity, payable at 65, whose promised payout depends on the contribution amount and the worker's age. The annuity promise, however, is not binding, as it might have to be adjusted downward later for actuarial sustainability. Upon retirement all the bits of deferred annuities are added up and become the actual annuity. To create a more competitive annuity market, workers were given the right to change pension funds (annuity providers) rather than staying with the fund chosen by the union. No workers have yet retired under this new system.

In addition to this quasi-mandatory annuity market, Israel has a small voluntary annuity market. Middle managers, not covered by the union agreement, are often given annuities by their employers as part of their compensation package; this is called "managers' insurance." Furthermore, and even tinier, is the annuity market for individuals. Neither of these voluntary arrangements is government subsidized. The entire market is dominated by three large companies, of which one has a market share exceeding $50 \%$. We present data on both voluntary arrangements (individual and managers' insurance) as well as the quasi-compulsory subsidized arrangement.

Canada and U.S. In contrast to the 6 cases just described, annuity purchase in the US and Canada is not part of a mandatory or quasi-mandatory program. Both countries offer tax-deferred voluntary retirement savings account during the working life (IRA's, 401k's, 403(b)'s and Keogh's in the US, RRSP's in Canada). An inducement to buy annuities comes at the age of 69 in Canada, 70 in the US, when holders of these accounts are required to start decumulating in the form of scheduled withdrawals or annuities. Scheduled withdrawals (called RRIF's in Canada), which allow individuals to retain control 
of the investment strategy but which do not provide longevity insurance, are most popular, just as allocated annuities are in Australia.

As a result of its voluntary nature, the annuities market is very small in both these countries and most so-called "annuities" are, in reality, tax-advantaged variable deferred annuities that are still in the accumulation stage. These carry an option to turn them into life annuities at the payout stage, but so far few people have exercised that option. To give an idea of relative magnitudes: In Canada in 1999, out of CAN\$11.1 billion paid in as premiums for individuals, only $19 \%$ was for the payout stage and only $6 \%$ was for the purchase of immediate life annuities. Group annuities (often purchased by small employers in settlement of their defined benefit obligations) formed another, smaller, part of the annuity market (Kim and Sharp 1999).

In the US in 1999 , out of $\$ 116$ billion in premiums paid for individual annuities, only $6 \%$ were for immediate annuities in the payout stage and much of these were for term certain annuities lasting for a specified period, rather than for annuities offering longevity insurance. Similarly, out of $\$ 154$ billion in the group market, only $24 \%$ was in the payout stage (Table 1). By far the greatest share, and the fastest growing share of the market, was for variable annuities in the accumulation stage. However, if individual accounts are adopted as part of the US social security system, and as $401 \mathrm{k}$ plans grow, we are likely to see the growth of this market and the development of new annuity products-most likely products that entail risk and return sharing between insurance companies and annuitants.

In sum, annuity markets seem to grow when they become part of the mandatory social security system, and that is happening in many countries. In countries where both coexist, the quasi-mandatory market is much larger than the voluntary one and much further growth is anticipated as none of these arrangements are close to maturity. Detailed incentives and constraints set by public policy largely determine how the annuities market evolves. This paper deals with the mandatory or quasi-compulsory markets in the UK, Chile, Australia and Singapore, the voluntary markets in Canada and the US and presents data on both markets for Switzerland and Israel. 


\section{Payouts}

Suppose a worker starts his career by earning $\$ 31,043$ (or pesos or pounds), works for 40 years with a real annual wage growth rate of $2 \%$ (due to economy-wide growth + age-earnings growth) and contributes $2 \%$ of his wage every year to a retirement savings account on which he earns a real rate of return of $5 \%$. Then, at the end of 40 years his final wage is $\$ 67,200$ and his retirement savings accumulation is $\$ 100,000$ (abstracting from inflation). If he turns this accumulation into an annuity, what will he receive in exchange for his $\$ 100,000$ ? In this section we investigate how the answer to this question varies by country, product and insurance company that is chosen.

Differences across countries. Table 3 presents average monthly payouts beginning at age 65 for a variety of annuity products in our sample of countries. These data are based on surveys conducted in each country during the spring of 1999, as part of this study. Insurance companies were asked what their monthly payouts would be for a variety of annuity products for a premium of 100,000 in local currency. These annuity products are almost all SPIA's — single premium immediate annuities—where the worker pays a single amount and immediately begins collecting benefits. The promised benefits take the form of 1) an individual level annuity that pays a fixed amount per month until the worker dies; 2) an annuity that provides a partial bequest in the form of 10 or 15 years of guaranteed payments (which would be paid to the beneficiaries in case of death), ${ }_{3}$ ) joint annuities that include survivors' insurance, with a specified percentage of the original benefit to the survivor in case of death; 4) an escalating annuity that increases a given \% per year; or 5) an indexed annuity that increases with inflation and thereby holds purchasing power constant. The guaranteed or joint annuities might be chosen by an individual who want to leave a bequest to his family; and the escalating or indexed annuities by a person who does not want his annuity to dwindle relative to prices or wages as he becomes very old.

Focus first on the individual level annuity for men in Panel A, row 1. We see there that a SPIA purchased for $\$ 100,000$ at the age of 65 will yield widely varying amounts ranging from $\$ 590$ in Switzerland to $\$ 740$ in Canada, with Australia and the UK in the middle. In the US the payout would be $\$ 733$ monthly or $\$ 8796$ annually, so our hypothetical worker who had a final annual wage of $\$ 67,200$ would get a replacement rate 
of $13 \%$ from his $2 \%$ annual contribution. In Switzerland his replacement rate would be less than $11 \%$. These differences may be due to: 1) international differences in interest rates; 2) different current mortality rates among annuitants in different countries; 3) different mortality improvement projections; or 4) different degrees of competition and willingness to accept risk on the part of insurance companies. In Parts III and IV we analyze whether these different monthly payouts also imply differences in expected lifetime benefits and how much each of these explanations contributes to the variation.

Differences across products. Moving toward other annuity products in Panel A, the data allow us to measure the trade-offs between different types of insurance that a worker might want to buy. In the UK, where the largest variety of products is offered, a male annuitant can get $\$ 727$ per month for an individual nominal SPIA, but if he wants to purchase a partial bequest in the form of a 10-year guaranteed payment he must forego $5 \%$ of that monthly benefit and gets only $\$ 691$. If he wants a joint annuity that will provide $50 \%$ of the original benefit to the survivor (who is assumed to be the same age in this example), he must forego $12 \%$ and will receive only $\$ 642$ monthly 8 In Canada, Australia and the US the trade-offs are not identical but they are similar. In most countries, the majority of annuitants choose to purchase guaranteed payments or joint annuities in order to provide a survivors' benefit, but they pay an opportunity cost in terms of a lower initial benefit.

Annuities that escalate at a fixed rate of 3\% per year start out with a monthly payout of $\$ 564$ in the UK. Of course, the payout automatically increases each month so after 9 years it passes the $\$ 727$ that the annuitant would have gotten with a non-escalating SPIA. An escalating annuity may be a crude way for payouts to keep pace with expected inflation; but it does not protect workers against unexpected increases in inflation. Only an annuity that is indexed to the price level will accomplish this. Panel B presents real price-indexed annuity payouts for the three countries where they have existed for some time. For the UK, the price-indexed annuity starts by paying only $\$ 522$ monthly, much less than the escalating annuity or the level nominal SPIA; clearly inflation indexation costs. Moving from the level nominal SPIA to the real SPIA cuts the initial payout by $28 \%$ and if we moved to a real joint annuity the payout would be reduced still further to $\$ 438$, a total cut of $40 \%$. The replacement rate of our hypothetical worker would, in that case, be less than $8 \%$ of final 
wage, instead of the initial 13\%, in exchange for inflation protection for himself and his beneficiary. However, it is interesting to note that the payout is highest of all in Chile, where all annuities are indexed-so indexation seems to have different effects in different contexts. In Part VI we suggest that this difference is due to the different types of financial instruments that are available for hedging inflation risk in the UK and Chile.

Panel C shows that if gender-specific mortality tables are used women get lower payouts than men. Their trade-offs are somewhat less because of their greater expected longevity, but the direction of the above relationships holds for them as well.

As described above, most of these annuity markets operate as part of a country's mandatory social security system. In such cases, governments often place restrictions on the type of annuity to be purchased and sometimes on price as well. Most common is the requirement for a joint annuity, designed to include survivor's benefits and prevent old age poverty among dependent spouses. Unisex tables, designed to prevent low incomes among older women retirees, is increasingly common, and price indexation is sometimes required. For example, in Switzerland a joint annuity with $60 \%$ benefit to survivor is required in Pillar II (whether or not the individual is married), and this form is also required for married men who purchase an annuity in Chile. Thus the mandatory markets for Chile and Switzerland are concentrated in joint annuities. In Switzerland, government regulations specify the actuarial factor that must be used when transforming the savings into a joint annuity; both for men and women the initial annual benefit must equal $7.2 \%$ of the retirement savings. This transformation yields $\$ 600$ monthly, which is $20 \%$ more than is available in the voluntary market. In Israel, too, the subsidized deferred annuity must be joint, with $60 \%$ going to the survivor, and is also higher than that available in the voluntary market. In Chile and Israel the annuity is price-indexed, as are all long-term financial transactions. In Switzerland, which has had low historical rates of inflation, the annuity is not indexed, although discretionary ad hoc adjustments are sometimes made. In the UK the annuity that must be purchased by age 75 with the mandatory contribution rebate must be indexed (up to 5\% inflation rate), joint (even if not married) and uses unisex tables, which would reduce the rate further for males - but this is a relatively new mandate in the UK. ${ }^{9}$ In contrast, in Singapore the annuity option is individual, not joint, but must guarantee the return of the worker's capital, which usually implies a 15-year payout guarantee. 
These requirements should be taken into account in projecting the retirement savings that will be needed to finance an acceptable income level in old age. Because inflation protection and/or survivors' insurance through joint annuities or period certain guarantees are often part of the package, the amount of savings and contributions required to provide a given replacement rate is greater than it would otherwise be; or the replacement rate will be much less than anticipated. Policy-makers should - but it is not clear that they do--take these trade-offs into account in specifying annuitization requirements. In some cases (e.g. Israel and Switzerland), a below-market price (abovemarket payout) is specified to avoid the higher savings and contribution rate. This in turn implies subsidization by government or cross-subsidization by other groups of consumers.

Payout differences across insurance companies. The numbers given above are all industry-wide averages. Table 4 presents evidence of price dispersion in Canada, Australia, Chile, the UK, the U.S. and Singapore. We see there that payouts are widely dispersed in the US-implying that the annuitant's choice of company matters--but tightly clustered in Canada and Singapore, where price dispersion is less than 5\% from top to bottom. The ready availability of on-line information in Canada and the standardized distribution of information by the Central Provident fund in Singapore may lead to clustering for companies that want to stay in the market. Factors such as a desire to increase sales at a particular time, or to offset life insurance risk, or to take aggressive advantage of good investment opportunities may explain high payouts. Low payouts may imply a decision to withdraw from the market. Unfortunately we do not know the quantities that go along with these prices. Anecdotal evidence indicates that in Switzerland and Israel regulations and cartel-like behavior among a concentrated number of firms keep prices even closer together. Underlying the similarities in price is the fact that SPIA's are a relatively standardized product where consumers, regulators and industry associations can compare prices with great ease. While simple products with limited choice do not allow all individuals to optimize, they have the advantage of facilitating price comparison and price competition. As more complex products are offered (e.g. with payouts tied to investment performance or mortality experience), price comparisons will become more difficult. We might then expect greater price dispersion, with competition taking the form of product differentiation and marketing. 


\section{Calculating the Money's Worth Ratio: Interest and Mortality Rate Assumptions}

Do these annuities provide good value for money? Are annuitants likely to get back the premium they pay in, over time? And does this hold across countries, even countries that offer very different payouts?

To answer these questions:

1. We calculate and compare the money's worth ratio (MWR), that is, the present value of the expected future payments relative to the initial premium cost, in different countries and for different annuity products. Concretely, the MWR for a single life annuity is:

$$
M W R=\left\{\sum_{t=1}^{(T-a)^{*} 12} \frac{P_{a, t} \cdot A_{a}}{\left(1+i_{t}\right)^{t}}\right\} / C_{a}
$$

where: $\quad \mathrm{T}=$ Maximum attainable age

$$
\begin{aligned}
& \mathrm{a}=\text { Age (in years) of annuitant at start of contract } \\
& \mathrm{t}=\text { Number of months beyond annuity starting date } \\
& \mathrm{P}_{\mathrm{a}, \mathrm{t}}=\text { Probability of individual being alive } \mathrm{t} \text { months after age a } \\
& \mathrm{A}_{\mathrm{a}}=\text { Monthly annuity payment for annuity purchased at age a } \\
& \mathrm{C}_{\mathrm{a}}=\text { Cost of policy for individual purchasing annuity at age a } \\
& \mathrm{i}_{\mathrm{t}}=\text { Nominal monthly t-period spot rate }
\end{aligned}
$$

The numerator of this expression is the "expected present discounted value" (EPDV) of the lifetime income stream from the annuity, while the denominator $C_{a}$ is the initial capital cost. If the MWR is $100 \%$, this means that consumers can expect to get back what they paid in, in addition to longevity and investment insurance. (100\%-MWR) is often referred to as the "load factor". If the MWR is considerably less than 100\% (a high load factor), consumers are getting back a lot less than they put in, and this may not be a good deal for them. If it is much greater than $100 \%$, this raises the prospect that insurance companies are offering too much in order to gain market share in the short run and may not be able to keep their promises in the long run; possibly regulators should be concerned. 
2. We measure the asset-based margin, that is, the subtraction from the risk-free interest rate, that consumers pay each year, in exchange for this insurance. If $\mathrm{m}=$ the margin, $i=$ the risk free rate and $r=$ the discount rate for which the MWR's in the above equation $=100 \%, \mathrm{~m}=\mathrm{i}-\mathrm{r}$. If the MWR when discounted at the risk-free rate is $100 \%$, this means $\mathrm{r}=\mathrm{i}$ and $\mathrm{m}=0$.

The MWR, clearly, depends on market payouts, interest rate and mortality rates. Interest rates turn future payouts into present discounted values while mortality rates turn them into expected values, depending on survival probabilities. Earlier studies done for the US and UK used, alternatively, the government term structure and the corporate term structure for discounting, and well-established mortality tables created by the government or the society of actuaries for computing expected values. Not surprisingly, when we tried to apply this procedure to countries where financial markets and mortality data are relatively undeveloped, methodological problems soon emerged.

\section{Interest rates}

Ideally, the discount rate used should reflect consumers' time and risk preferences, which should also coincide with the rate available on alternative investments. Using the term structure of government interest rates as a risk-free rate would be appropriate for consumers who had savings, preferred (or were at the margin of making) risk-free investments, and considered annuities completely safe. For consumers with a preference for riskier assets, or those who consider annuities unsafe, a higher discount rate is appropriate. Mitchell, Poterba, Warshawsky and Brown (1999) and Brown, Mitchell and Poterba (2000) used the AA corporate bond term structure as their risky discount rate. Consumers who have no voluntary savings, are liquidity constrained or are borrowing rather than investing might have an even higher discount rate.

To start with, we use the government rate as a risk-free benchmark by which to measure the relative return to consumers, across countries. However, since most low earners have little voluntary savings and many high earners probably want to invest in riskier assets with a higher expected return, it is likely that for many potential annuitants the appropriate discount rate is higher than the government rate. Moreover, as we show later, the portfolios in which insurance companies invest are not completely safe. Therefore, we also present results for a "risky" rate: the government term structure+1.4\%. This is close to 
the risky discount rate used by Poterbo and Warshawsky (2000). As we shall see, it corresponds to the rate of return on investments which would be just high enough to cover insurance company costs, and it is a better approximation of their actual portfolios.

Both short and long term government rates and corporate rates, are available in the US, UK and Canada. However, in most of the countries in our study long-term government bonds are not available. For example, in Australia the longest government bond is 12 years. In Singapore, where the government doesn't run deficits but issues bonds only to build the bond market, government bonds are scarce and the term limit is 10 years. In Israel it is 15 years and in Chile 18 years. The corporate bond market is even more limited and shorter term. Apart from the US and Canada, corporate bond terms rarely exceed 10 years - and this includes well-developed markets such as Switzerland, the UK and Australia. In Israel the corporate bond market hardly exists. In Singapore it was meager before 1999, when the Monetary Authority of Singapore began to allow statutory boards, banks, finance companies and foreign corporations to issue bonds--partly motivated by the perception that insurance companies would soon need these investments. In Chile, too, impetus to the corporate bond market has been given only by the pension reform. Where they do exist, the spread between high grade corporate and government bonds is usually less than $1 \%$, so a risky discount rate of $1.4 \%$ implies some investments in lower grade bonds, mortgages and/or equities — consistent with insurance company portfolios.

Where long-term rates were not available we extrapolated forward the last available government bond rate, into the future. On the one hand, this procedure may understate the appropriate discount rate since it ignores increases in uncertainty for consumers and reinvestment risk for insurance companies as time extends. On the other hand, annuities may constitute one of the few available long-term investments for consumers in incomplete markets, so they may discount benefits in the distant future at a lower rate because of the scarcity of such options. ${ }^{10}$ In general, the absence of varied long term financial instruments is expected to make annuity provision more costly and also makes it more difficult to measure the money's worth to consumers. Many countries that have recently reformed their social security systems to include individual accounts are in this difficult situation.

Both the level and slope of the yield curve vary among the countries in our sample, in ways that may affect payouts and MWR's. For example, the level is relatively low in 
Switzerland and relatively high in Chile. In Israel the term structure is almost completely flat, while in the UK it falls, in the US and Canada it rises gradually and in Singapore and

Switzerland it rises steeply with term. ${ }^{\mathrm{m}}$ We would expect the following relationships to hold:

1. Higher interest rates would lead to higher payouts (because they provide a higher return on insurance company investments) while if the payouts were actuarially fair the MWR would be unaffected.

2. In contrast, steeply rising interest rates would lead to higher MWR's (because consumers will be discounting the early years at low rates while insurance companies can invest in long term instruments and avoid reinvestment risk).

3. In some countries (e.g. Singapore and Switzerland) insurance companies may, because of regulation or cartelization, follow smoothing policies that hold annuity prices constant through time as interest rates change. In these cases, current interest rates would not be a good predictor of current annuity payouts or MWR's.

We will return to these hypotheses later as we analyze empirically the impact of interest rates on payouts and MWR's across countries. Appendix F presents our term structures.

\section{Mortality tables}

Period and cohort mortality tables: what are they and do they exist? Consumers and companies need cohort mortality tables to calculate the expected lifetime payouts of the annuity. A cohort table shows, for any given cohort such as all those who are age 65 today, its age-specific mortality and survival probabilities.

To construct a cohort table one starts with a period column that displays mortality rates based on cross-sectional data for different age groups within a time period such as 1996-98. This gives us a single age-specific mortality rate for each age, which applied in 1996-98. If mortality rates did not change, this would also give us the age-specific mortality rates for all cohorts. However, mortality rates have been falling continuously over time so it is necessary to build in a longevity improvement factor per year to show how the period column is likely to evolve through time - the period column for 2010 will show lower mortality at every age than the period column for 1996-98. From this set of period tables we can build a cohort table, which shows different age-specific mortality rates for each cohort. For the cohort that was 65 in 2000, mortality increases as individuals age, but the mortality 
improvement factor retards this rate of increase. The individual who will be 75 in 2010 will have lower age-specific mortality rates than the individual who was 75 in 2000. If I do not take into account that I will probably live longer than my parents, I will underestimate the benefits from annuitization. If insurance companies do not take projected longevity improvements into account they overestimate how much they can pay each year and still cover their costs. Cohort mortality tables include such improvement factors. However, cohort tables depend on guesses about future longevity, which no one knows for sure. The next section deals with this uncertainty.

In addition to the need to project longevity improvements, insurance companies must take account of the differences between the mortality of annuitants versus the population as a whole. Often, only population-wide data are available, collected by the government, but companies really want to know about the annuitant group, whose mortality rates may be lower (see discussion of adverse selection below). However, especially in the early years of an annuity market, cohort tables for the population and period or cohort tables for annuitants may simply not be available. And when annuitant data exist they may have been collected by separate companies that consider them proprietary and do not make them publicly available. That is exactly what we found - and it poses a potential problem for countries newly developing their annuity markets as part of their mandatory systems. Below we summarize how we handled this problem in our calculations and further details are given in Appendices A, B and C.

Of all the countries in our sample, the UK has the most developed financial market and longest-standing pension industry, largely based on employer-sponsored pensions. Pension plans of large employers were self-financed but small employers often obtained annuities through insurance companies. These employer-sponsored pension plans are now part of the quasi-mandatory retirement savings program in the UK, since they function as an optional alternative to the state's pay-as-you-go defined benefit plan (SERPS). The UK began collecting data on pensioners' mortality in 1955-58, then recalculated every 4 years, in a series called "life office pensioners". Initially the data had few females and few males over the age of 90 but it now has many more. Since 1980 an improvement factor, devised by an industry body, the Continuous Mortality Investigations Bureau (CMIB) has been built in, to enable the construction of cohort tables, but actual longevity improvements have 
generally exceeded expected improvements; that is, actual deaths have been less than expected deaths.

Until recently the UK did not have data on retirees with personal pensions, a growing group under the current UK scheme which permits workers to opt out of the state or employer-run plans into their own personal plan. A new table indicates that this group may have lower mortality rates than the others, but experience is small (Murthi, Orszag and Orszag 1999; Finkelstein and Poterba 1999). Fortunately, all these UK tables are public information and UK data for employer-sponsored plans have served as the basis for mortality tables in many other countries. We use the pensioner cohort tables for calculating the MWR in the UK, in this paper.

In contrast to the UK, the Australian annuity business is developing only now, as a consequence of its new superannuation scheme, which requires workers to accumulate large retirement savings. Population cohort tables were constructed only recently in Australia. The absence of previous life or annuity business means that no annuitants' mortality table has been constructed. Instead they use a period table based on UK annuitants in 1980, with an allowance for mortality improvements up to 1999. Australian regulators assume that current retirees in Australia will have a mortality rate $60 \%$ that of the 1980 UK table. This seems to fit recent Australian experience with males but may underestimate their survival rate as they age and, even more, may underestimate the increasing longevity of older females. We turned this period table into a cohort table by applying the same improvement factor for future annuitants as was used in constructing the population cohort table (Knox 1999).

In Switzerland the first population cohort tables were published by the government in 1998. Annuitant tables, produced by the Life Insurance Association, have long existed but are proprietary and not publicly available. However, similar data supplied to us by a large life insurance company reflected period mortality experience and projected improvement factors for pensioners in the quasi-mandatory second pillar and the voluntary third pillar. Mortality rates for the latter group are by far the lowest and mortality improvement rates among the highest in our sample of countries.

In contrast, cohort tables simply do not exist in Singapore, Israel or Chile. Singapore's annuity market started in 1987 when annuities became one of the allowable 
options for the retirement savings that workers were required to accumulate in their retirement savings accounts (the Minimum Sum Scheme). However, the companies have little data on which to base their pricing. Population mortality data published by the government are given in five-year age categories, rather than for each age separately, and without any projected improvement factors. Therefore, Singapore, like Australia, uses UK data, this time from 1967-70, with mortality improvements projected to 1990 and with a two-year setback to account for lower mortality among annuitants. (A two-year setback means that a 65 year old is treated as having the same mortality rate as a 63 year old has in the initial table). In Singapore, where people are quite healthy, the scanty evidence available thus far suggests that actual deaths are far less than expected (Chang 1999).

In the past Israel has also used UK tables, and for survivors and disability insurance Swiss tables, in both cases adjusted for Israeli experience. Currently, insurance companies are legally required to use a 3-year setback of the population period tables as an estimate of annuitant mortality. Recently an actuaries' committee developed another period table that is supposed to be a more accurate representation of annuitant mortality, but has yet to be implemented (Spivak 1999).

Until the mid-1980's Chile relied heavily on US mortality data but, spurred by the emerging demand for annuities at that time, it began to develop and up-date its own annuitant and population mortality tables, based on census and social security data. Cohort tables do not yet exist (Callund 1999). ${ }^{12}$ We use the population period tables for 1996, calculated by the Institute Nacional de Estadisticas and the new annuitant table for 1998 developed on the basis of AFP experience during 1983-96. For MWR calculations in Table 4 for Chile, Singapore and Israel we use the period tables that are employed in these countries. In table 5 we "cohortize" these data by applying the Canadian mortality improvement factor as a proxy.

The US and Canada have the opposite problem from other countries--many mortality tables are publicly available, each based on somewhat different data, smoothing methods and projection factors. The results will vary slightly, although not grossly, depending on which table is used. In the US, the Social Security Administration constructs population period and cohort tables, with high, medium and low improvement scenarios, as part of its regular periodic reports. The Society of Actuaries constructs period annuitant 
tables, with longevity adjusted upward from its basic 1983 tables. Recently this was projected forward to become the 2000 tables. Mitchell et al 1999 and Brown, Mitchell and Poterba 2000 turned these into cohort tables by applying the medium-improvement factor from the latest SSA report to the SOA tables. For comparability, we have used their resulting tables in this paper. For sensitivity analysis, in Appendix D we present calculations based on historical data for Canada and the US supplied to us by SSA (see Goss et al 1998).

Projections about future life expectancy. Even in the presence of accurate public information about past and current mortality, it is difficult to construct cohort tables and value annuities because future life expectancy remains an unknown. (For thorough reviews of the literature on this topic, including the variety of forecasting models and their shortcomings, see Tuljapurkar and Boe 1999; Bongaarts and Bulatao 2001).

One possible reason for the low voluntary purchase of annuities is that people have consistently underestimated their life expectancy, basing their guesses upon the death rates of people around them now, rather than on what is likely to happen in the future, i.e. without factoring in the mortality decline that will occur over their lifetimes. Betterinformed government actuaries, too, have consistently underestimated longevity improvements. Until 1980 UK actuaries did not build an improvement factor into their tables, nor was this done initially in the US social security system, leading to predictable underestimates of system expenditures. Similar underestimates have occurred in the private insurance sector. Annuity providers in the US lost money in the late 1930's, both because interest rates fell and because life expectancy turned out to be longer than expected (Poterba 1997). It has been argued that some insurance companies in the UK have underestimated average life expectancy of their annuitant pool by two years or more, which could cause a loss that will become apparent in the future (Blake 1999). 13

When working with these projections, very different methods are used in different countries. In the US, UK and Australia, at the population level, historical data by age, sex and cause of death are taken into account (Friedland 1998; Knox 1999). In Canada, additionally, projected real wage improvement enters into the projection of future mortality. Since real wage growth is expected to fall, so too is mortality improvement, in the future (Friedland 1998; Goss et al 1998). Australia projects higher improvement factors for the 
first decade than for the longer run. Usually past trends have been slightly modified and extrapolated; but unfortunately past trends in these underlying factors are not necessarily indicative of future trends. In particular, distortions can result from projecting recent short term improvements into the future, as some studies have done in building cohort tables (see Doyle, Mitchell and Piggott 2001).

As one empirical example of the wide variation in improvement rates across countries and over time: over the twentieth century the average annual percentage reduction in death rates for men $65+$ was $.2 \%$ in Canada, $.5 \%$ in the US and $1 \%$ in Mexico. In Canada, mortality rates actually increased (negative improvement) during the first part of the century. But during the last 20 years, Canada has improved more than the other two countries. For the US, the average annual improvement rate for men by decades ranged from $-.5 \%$ during the 1920 's to $1.5 \%$ in the 1970 's to $.4 \%$ in the 1990 's. For most of the period in the US female mortality improved faster than male mortality but during the past 2 decades this pattern has been reversed (Goss, Wade, Bell and Dussault 1998; also see summary in Friedland 1998). Over-all, the mortality improvement factors implied by these data for the future are higher than those used in our calculations for the US, supplied by Brown et al (2000), but lower than those used for Canada, based on Canadian Pension Plan (CPP) projections. However, both sets of US improvement projections are very small compared with those of other countries in our sample. (See Appendix D for more details about this comparison).

In addition to these difficulties in projecting population mortality, the annuitant group may improve faster or slower than the population at large, depending on the underlying mortality model and the selection process that is at work. If life style forces are responsible for mortality improvement, annuitants, who tend to be more educated and have a longer time horizon, might experience a faster increase in longevity. But if the annuitant group has become less selected as a result of policy change, longevity of future annuitant cohorts might increase slower than that of the population at large. In most of our sample countries the improvement projection factor is assumed to be the same for population and annuitants.

In the UK and Switzerland industry bodies make the projections for annuitants and are responsible for the faster improvement postulated. In Switzerland the process for 
making these projections about annuitants is highly secretive. In the UK details of the deliberations of the Continuous Mortality Investigation Bureau (CMIB) appear on the web www.actuaries.org.uk CMI Reports \#16 and 17). During the latest round of up-dates the CMIB deliberated whether the same improvement projection should be made for all groups including company pensioners, voluntary individual annuitants, males and females. Although the actual experience of these groups has been quite different, the committee decided to keep the improvement projection identical, for purposes of simplicity. Its initial projection was discussed broadly among actuaries and others, and raised upward as a result. This process illustrates the uncertainty and subjectivity of cohort mortality tables, even in situations where they are done very carefully. Selection into the group of personal pensioners is expected to expand rapidly and to become a more broad-based group, one of the reasons that UK insurance companies do not want to assume lower mortality and faster mortality improvement in this category.

Appendix E1 presents the mortality tables for all eight countries in our sample and E2 presents the improvement factors (IF's) used in the five countries that had cohort tables. Except for the US, the annual IF's range from over $2 \%$ for the "young" old to less than .5\% for the "old" old. Table 5 illustrates the differences in life expectancy at age 65 and expected present value of lifetime payouts with and without the mortality improvement factor (period versus cohort tables) for the population and annuitant groups in our sample countries. The difference is noticeable but not huge. Except for the US, life expectancy gains at age 65 due to mortality improvement are slightly more than one year and lifetime payouts jump 3-4\%. The average population male is expected to live 16-17 years after retirement at age 65 (19-20 years for females) and annuitants' live another 2-4 years beyond that. To deal with the possibility that different apparent MWR's across countries may simply be an artifact of the different methodologies that they used for predicting the future, in some analyses we "standardize" the mortality improvement factor (see Tables 7 and 11).

The wide variance in mortality improvement factors and interest rates across countries plus the fact that different methods have been used in different places raises the question of who will bear the risk if the projections turn out to be too low or if interest rates change unexpectedly. This suggests that: 1) in some cases the true MWR may be lower than given here, if longevity has been overstated or long run interest rates understated, and 2) 
thought must be given to who will bear the risk if longevity increases or interest rates fall much faster than insurance companies expect. We will return to this important policy question below.

\section{The High Money's Worth Ratio of Annuities}

Table 6 presents the MWR for annuities that begin at age 65 for our sample countries, in 1999, using the government bond "risk-free" rate and the mortality tables in use in each country. As discussed, cohort tables are not used in Israel, Singapore and Chile, and cohort tables for the other five countries use varying mortality improvement projections. To facilitate comparability and to investigate how much difference this makes, we went back to the original period tables for all countries, applied a standardized improvement factor - the factor used in Canada - to bring the period tables up to 1999, and then "cohortized" them, using that same standard factor. Canada was chosen as a base because it has an intermediate improvement factor-higher than the US but lower than Switzerland. This standardization makes the countries using period tables more comparable with the others, and avoids MWR differences stemming from different projection methodologies across countries, but it also omits justifiable differences in future improvement projections. Table 7 presents the standardized MWR's for all 8 countries.

A few points should be made about special situations. For Switzerland, Pillar III annuities typically include a "bonus" that is $7.8 \%$ of the total payout. This bonus is not guaranteed but it has been paid regularly for many years. This may be one mechanism used to raise payouts for annuitants while cushioning risk for insurance companies. We present the MWR with and without the bonus. Also for Switzerland we present the MWR for the quasi-mandatory annuity in Pillar II, which allows us to compare voluntary and compulsory contexts. The form and payout on this annuity are set by the government: it must be a joint annuity with $60 \%$ to survivor, that annually pays $7.2 \%$ of the worker's total accumulation at retirement, both for men and women. This actuarial factor has been constant since Switzerland started its system in 1985-despite falling interest rates and rising longevity. However, it is scheduled to fall gradually to $6.65 \%$ by 2015 . 
For Singapore, where annuities are purchased under regulations of the Minimum Sum Scheme, the required return of capital guarantee is usually implemented in the form of a $15 \mathrm{YG}$, which we present here. Our method for handling the fact that it is a deferred annuity, purchased at age 55 for disbursements beginning at age 62 , is described in Appendix A.

For Israel, we present results for voluntary annuities that are sold to individuals and, through employers, to managers, using the recently developed actuaries' period mortality tables in Table 6 as well as the standardized cohortized versions in Table 7. Additionally, we present the MWR for the quasi-mandatory deferred annuity that is purchased in bits throughout the worker's life. This requires a complex calculation that is described in Appendix B.

Differences across countries. Looking now at Table 6, we observe that the variance in discounted lifetime payouts is much less than the variance in monthly payouts. Among annuitants, the MWR's exceed $95 \%$ for practically every country (exceptions are the voluntary annuities in Israel and indexed annuities in the UK) and in several instances exceed $100 \%$. The US, UK and Canada, which operate in the freest markets, are tightly clustered between 97 and 98\%, consistent with earlier studies. Although Switzerland has the lowest monthly payout, it has the highest MWR in the voluntary market - $108 \%$, when the bonus is included. While the bonus has been constant for many years, it can be eliminated at the discretion of the insurance company, and therefore constitutes a risksharing technique. Without the bonus, the MWR falls to $100 \%$. Thus the low payout does not imply low value to consumers, if the mortality rates used in these calculations are correct.

The highest MWR's are found in the quasi-mandatory heavily regulated systems of Switzerland (120\%) and Israel (109\%). In Israel this is facilitated by a direct subsidy in the form of access of pension funds to above-market interest rates on government bonds. In Switzerland price is set by the government and hidden cross-subsidization across generations and product lines must be involved. For example, the same insurance companies often handle the accumulation stage as well as the payout stage, and may earn a profit on the former that is used to cross-subsidize the latter. Insurance companies in Switzerland are not anxious to increase their Pillar II business but are reluctant to cancel 
what they have because of tied business as well as their long-standing relationships with clients.

Differences across products and gender. Despite their very different payouts that were discussed above, all the nominal annuity products offer virtually the same MWR to annuitants. Similarly, although payouts were much lower for women, the MWR is very close for both genders. This suggests that the differential monthly payouts are largely due to the different expected time patterns of payment across products and genders.

One important exception is the much lower MWR offered for price-indexed products in the UK, compared with nominal annuities in the UK, suggesting that inflation protection is costly. But price-indexed annuities in Chile have high payouts and similar MWR's to nominal products in other countries; so they do not always cost more. We hypothesize the load factor on indexed annuities depends on how much of the spread insurance companies have to surrender to protect themselves against inflation risk when they offer indexed annuities; and this in turn depends on the variety of indexed financial instruments available in the economy.

Impact of standardizing mortality improvement projections. Comparing Table 6 with Table 7, which standardizes the mortality improvement projection, we see this produces an increase for the US, which used only a small improvement factor, and for Chile, Singapore and Israel, which did not impute an improvement factor of their own, but a decrease for Switzerland, which imputes a high improvement factor for annuitants; but the changes are only $2-4 \%$ and the range is largely unchanged. This lack of sensitivity is encouraging given the uncertainty and variation in future mortality projections. This relationship is examined in greater detail below.

The small "margin." This picture is reiterated when we examine the "margin"the amount by which the equivalent annual asset-based return to the average annuitant lies below the risk-free return (Table 8 and Murthi, Orszag and Orszag 1999). As a rule of thumb, given these life expectancies, each point of MWR translates into $.12 \%$ of margin. Thus, the margin is only 20-30 basis points for the average annuitant in most countries and in some cases this charge is negative, corresponding to an MWR $>100 \%$. We sum up our findings thus far by noting that, in our sample countries, if people want a risk-free annuity 
and if these annuities are indeed risk-free, the average annuitant has gotten a good deal, paying virtually nothing for longevity and investment insurance.

The lower MWR when discounting at the "risky" discount rate." However, many people do not consider the annuity safe or do not want a risk-free investment; they might prefer to accept more market risk in exchange for a higher return. Also, many individuals borrow at high rates and take other actions to front-load their consumption, consistent with empirical evidence that subjective discount rates are often high. For example, a recent study of the willingness of US military personnel to take lump sum separation allowances versus annuities indicates personal discount rates exceeding $18 \%$ for most. ${ }^{14}$ For such consumers, discounting the proceeds of an annuity at the low risk-free rate overestimates its present value to them. For consumers who regard the annuity as unsafe, or who would prefer more risky higher-yielding investments, as well as those who have a higher time preference, a higher discount rate is appropriate. Many potential annuitants probably fall into these categories.

We therefore recalculate the MWR for these groups, using the government term structure $+1.4 \%$ (Table 9). We use 1.4\% because it has been used by others (Poterba and Warshawsky 2000) as an indicator of the risk in a typical insurance company's portfolio. Additionally, it approximates the return on investments that companies must earn or the charge which they must extract from consumers to cover their costs. With this higher discount rate the MWR for annuitants falls by 10-12\%. For individuals with higher discount rates, the load factor would be higher still. The smaller MWR received by people with a higher time preference and those who prefer to accept higher risk in exchange for a higher expected return, may go far toward explaining why the demand for annuities has been very low in most countries.

The lower MWR for the average population member. The MWR's also drop substantially, by $6-12 \%$, if we apply the higher mortality rates of the average population member. As a typical example: using the risk-free rate, an average Canadian worker who wants to buy an individual level SPIA will get an MWR of only 91.4\%, compared with $98.1 \%$ for the average annuitant. This phenomenon, sometimes ascribed to adverse selection, is often given as the reason for the low purchase of annuities. In interpreting these data, it is important to distinguish between "active" selection that is due to asymmetric 
information about expected longevity and "passive" selection, that is due to positive correlations between socio-economic status, longevity, and purchase of annuities. These two types of selection have quite different policy implications, since only active selection implies market failure. ${ }^{15}$ For other insurance proudcts, companies have invested in information that allows them to place different consumers in different risk categories, thereby counteracting active selection based on asymmetric information. This has not yet happened in the annuity market, perhaps due to its small size. As for passive selection, we expect to find it in purely voluntary markets, due to a positive income and wealth elasticity of demand for annuities.

While passive selection may diminish in quasi-mandatory markets, sometimes the rules of the mandatory system structure it back in. First of all, coverage in these markets is often only partial and lower income workers (who tend to have lower longevity) tend to be the excluded group, especially for second pillar arrangements. For example, in Chile only $60 \%$ of the labor force is covered by the new system; informal sector and agricultural workers are excluded. And the lowest income covered workers, who qualify for the minimum pension guarantee, are not permitted to purchase annuities, while annuitization is encouraged for early retirees, who constitute the highest income workers. In the UK the lowest earners tend to remain in SERPS, the state DB plan, instead of the system of private personal accounts or employer-sponsored plans. In Switzerland and Australia contributions to retirement savings accounts are not mandatory for low earners. Secondly, the fact that these systems are still immature suggests that only the better-off workers who were covered in the pre-mandatory days have large enough accumulations to annuitize currently. All these factors imply that some selection will remain, even in quasi-mandatory systems. Nevertheless, we would hypothesize that selection will be lower (1) in quasi-mandatory systems where payout options are restricted, as compared with purely voluntary systems, (2) in countries where the public pillar provides a lower replacement rate, hence does not crowd out annuitization by middle income groups, and (3) where income and wealth inequality, hence the relevance of passive selection, is smaller.

Given all these possible variations, as well as imprecision in mortality data, our current sample is obviously much too small to test these hypotheses econometrically. However, using the standardized mortality improvement factor in order to control for different 
guesses about the future, we find patterns that are consistent with these expectations (Tables 7 and 10). Selection (as measured by the difference between population and annuitant MRS) is lowest in Singapore and the UK--where the annuities market is part of a quasimandatory system that has existed for some time and where the public benefit is exceptionally small ${ }_{\text {and in }}^{16}$ anada, which has the least inequality in our sample. ${ }^{17}$ In Switzerland selection is much smaller in the quasi-mandatory pillar (II) than in the voluntary pillar (III), which tops up a generous replacement rate in Pillars I and II. ${ }^{18}$ In Chile the structure of incentives and constraints within the mandatory system, that we have already described, results in noticeable selection.

For all countries, we would expect products to develop that would attract lowlongevity individuals. Examples of such products are the 10 or $15 \mathrm{YG}$ and joint annuities, where expected payouts are less sensitive to the expected lifetime of the primary beneficiary so the difference between population and annuitant MWR is smaller. Additionally, we would expect this difference to be smaller (1) when the higher "risky" discount rate is used, since this depresses the present value of benefits for long-lived annuitants; and 2) for women, whose longer expected lifetimes mean that part of the difference accrues in the distant future, which is discounted more heavily than the near future. This is indeed the case. For example, in Canada's voluntary system the difference in MWR falls from 6.7 percentage points for male purchases of the level SPIA to 4.1 for the joint annuity (both discounted at the risk-free rate) to 3.5 when the "risky" discount rate is used to 1.7 percentage points for female purchases of the $10 \mathrm{YG}$ at the risky rate (Tables 610). Thus, if the risky rate applies to many people because of their time or investment preferences, and if products such as joint annuities and 10YG are popular because of their bequest value, load differentials between the average population member and annuitants are compressed and do not seem to be the main reason for the low purchase of annuities.

\section{How do we explain differential monthly and expected lifetime payouts (MWR's)?}

Earlier we found that the MWR's across countries and products are less dispersed than the monthly payouts. This suggests that the monthly payout differentials are needed to produce approximately the same lifetime expected present value (EPDV) of benefits; they are not simply random variations. In this section we analyze the degree to which the payout differences are due to interest differentials, current mortality rate differentials and 
differences in mortality improvement projections. This distinction is important because interest rates are exogenously given so causation is clearly one-way while future mortality projections are quite subjective, sometimes made by people associated with the industry, and may be determined simultaneously with payouts and MWR's.

It is difficult to compare interest (or mortality) rates in two countries directly, because they may be higher in country A for one term (or age) and in country B for another term (or age). Instead, we examine the impact of differential interest and mortality rates on monthly payouts and expected lifetime payouts for annuitants with the level SPIA. We find that interest rate differentials play the most important role in explaining differential monthly payouts, in the following sense: Once we know the country-specific term structures of interest rates, we are able to predict with considerable accuracy the actual monthly payouts that will be offered in each country, simply by assuming they all have the same standardized mortality tables and end up paying the same lifetime payouts. Under the assumption of standardized mortality tables, it turns out that monthly payout differentials are just enough to offset discount rate differentials and achieve similar lifetime payouts across countries. Once own-country mortality is introduced, greater differences in lifetime payouts emerge, and these appear to stem from differences in mortality tables, especially in projected improvement factors.

We show this in Table 11 by standardizing all these variables at the level found in one country, Canada (column 1), and then sequentially introducing own-country monthly payouts (column 2), own-country term structure (column 3), own-country period mortality rates (column 4) and own-country improvement factors (column 5) - calculating the EDPV and MWR in each case. (Column 4 corresponds to Table 5 and column 5 corresponds to Table 6). If monthly payouts differ while everything else is standardized, this should and does produce wide differences in EDPV (column 2). But as own-country interest and mortality rates are introduced, this should bring the EPDV of lifetime payouts back toward equality with Canada's, if both these variables matter and if market competition leads to similar loads across countries.

We find that substantial equality is achieved in EDPV's and MWR's among annuitants, corresponding to the relative lack of dispersion in Tables 6 and 7 . Whereas the MWR's for male annuitants in column 2 range from $78 \%$ to $109 \%$ (a range of 31 
percentage points), the range is cut to 12 percentage points when own-country interest rate are entered in column 3. Both the range and standard deviation, as simple measures of dispersion, are minimized in column 3-which is based on country-specific discount rates but standardized mortality rates. And the average is close to Canada's. Thus we can predict monthly payouts by using the mortality tables of one country, i, as a common standard, allowing interest rates to vary across countries, and finding the country-specific payouts that will yield the same MWR as in country i. Predictions made in this way fall within 4\% of actual payouts for 6 countries and within $10 \%$ for all countries in our sample, using Canadian mortality rates and MWR as the common standard. Introducing own-country mortality rates does not increase the accuracy of these predictions, on average. While these precise numbers hold for males, who dominate among annuitants, the over-all picture is the same for females. This implies that varying term structures play a key role in explaining varying monthly payouts - which is reassuring, given their obvious exogeneity. This is also consistent with our hypothesis that insurance companies cover their costs out of investment returns, which strongly influence their calculation of affordable payouts.

To investigate further this relationship between interest rates, monthly and lifetime payouts, Table 12 displays the rank order of countries by their (1) medium-term interest rate (the 8-year spot interest rate), (2) monthly payouts on the level SPIA for males, (3) expected lifetime payouts, holding mortality rates constant across countries, (4) expected lifetime payouts, allowing for country-specific mortality rates, and (5) projected improvement factors. We find an almost perfect rank order correlation between columns (1) and (2), suggesting again that monthly payouts are very responsive to interest rates. In contrast, we find no particular correlation between columns (1) or (2) versus (3) or (4): neither interest rates nor monthly payouts are correlated with lifetime payouts based on standardized or country-specific mortality. But, with the exception of Singapore, column 4 is perfectly correlated with the improvement factor in column 5. In particular, when ownmortality rates are applied, countries with outlying lifetime benefits are seen to be those with outlying improvement factors. A sequential process is suggested by these data: the interest rate structure determines monthly payouts while the projected improvement factor determines the country's measured MWR. Knowledge of the improvement factor used in the MWR calculations therefore allows us to predict whether a country's expected lifetime 
payouts will deviate substantially from those in other countries, while the monthly payouts have already been determined by interest rates. 0

Israel is a case in point at the bottom end; its low interest rate leads to low monthly payouts and, since it uses period tables only, with no improvement factor imputed, it has the lowest EPDV of lifetime payouts. And Switzerland fits this pattern at the upper end. Switzerland has the lowest monthly payouts but the highest expected lifetime payouts in the voluntary market. Table 11 tells us that its low monthly payouts are due to low interest rates, while its high average lifetime benefits and MWR are due primarily to the low mortality rates and high mortality improvement projected in that country for annuitants. The improvement projection is strongly influenced by the industry in Switzerland. It generates a high measured value for consumers while building in a cushion of safety for the

companies. 12 If the high mortality improvements do not materialize, the Swiss MWR will be closer to international norms. If they do materialize, companies can protect themselves by eliminating the bonus, which is a risk-sharing device.

Given the subjectivity in constructing cohort tables and improvement factors, analysts should view with caution the outlying MWR's that stem from unusual mortality tables. Since insurance companies seem to set loads close to those in other countries when these are evaluated according to standardized cohort tables, perhaps even they are wary of their own outlying mortality improvement expectations.

\section{Administrative Costs of Providing Annuities}

When issuing annuities, companies incur costs. One object of this paper is to figure out how they cover these costs, given the observed MWR's to annuitants in the vicinity of $100 \%$. We seek now to estimate how high these costs are. It is difficult to obtain cost data but we present data culled from a variety of published and unpublished sources. We present these costs as a $\%$ of premiums and as a $\%$ of assets per year.

The biggest cost item and the one that varies most across countries is marketing costs - much as it is for the accumulation stage of competitive retirement accounts that operate through the retail market. In the U.S. sales commissions on immediate annuities are about $4 \%$ of premiums, with total distribution costs amounting to $5-6 \%$ of the initial 
premium. Marginal operating expenses of immediate fixed annuities are low because the premium per policy is large relative to other kinds of insurance (e.g. see average premium per annuity contract versus per life insurance contract for Singapore in Table 1), is fully paid in one lump sum, consumers can't switch companies or investment options, and don't need to be serviced in other ways; only the monthly check must be mailed out. Using a $\$ 100,000$ policy as our model, first year set-up costs are about $\$ 100-\$ 300$ or $.2 \%$ of the premium and small annual operating expenses (for issuing monthly checks, annual statements and other communications with annuitant) add $\$ 40-50$ per year, or another .6\% of the initial premium when capitalized. Investment costs on long-term instruments run less than $.2 \%$ of assets per year, and these are usually netted out of investment returns. Data collection, actuarial analysis and overhead expenses (space, support services) that are shared with other products add another few basis points per year to costs, bringing total administrative costs to $7-8 \%$ of premiums or $1 \%$ per year of assets.

These numbers do not include compensation for the equity that must be tied up in reserves or for the mortality and reinvestment risk that the company has accepted. If the average annual rate of return on investments turns out to be 1 percentage point lower than expected, this reduces the present value of future earnings by about $8 \%$ of the premium, and could turn a potential profit into a loss. If life expectancy increases by one year more than expected for a given cohort, this increases the present value of future expenditures by $2-3 \%$. Besides the reserves that are held to cover expected liabilities to policyholders (as required by regulations), prudent insurance companies may hold additional reserves to cover these and other risks ("free capital"). Insurance companies can be expected to charge loads for bearing these risks and for the opportunity cost of their equity. This could raise total costs to $10-12 \%$ of premiums or $1.3-1.5 \%$ of assets per year.

Other countries have similar costs, but with some interesting variations. In Australia sales commissions are also $4 \%$. In Chile they are 5-6\% of premiums, but part of this is unofficially said to be rebated to consumers, so the net commission kept by the sales person may be lower than that in the US and Australia. (In our MWR calculations we have ignored these rebates, which would reduce the initial net premium and increase the MWR). In Canada sales commissions (and therefore total costs) are somewhat lower--3\% in commissions for the first $\$ 100,000$ in premiums, falling to $1 \%$ for larger marginal amounts. 
In the UK commissions are reported to be only $1 \%$. In Israel, total administrative charges for the quasi-mandatory deferred annuity cannot exceed $8 \%$ of premiums, by law. And in Singapore total costs are estimated to be only $4 \%$ of premiums, including a $1 \%$ sales commission. (Knox 1999, Callund 1999, Spivak 1999, Kim and Sharp 1999, Murthi, Orszag and Orszag 1999, Chang 1999). Thus in many cases cost might be less than appears to be the case for the US.

The key to lower administrative costs in the annuity stage, as in the accumulation stage, of retirement savings plans appears to be lower marketing expenses. In Singapore the Central Provident Fund standardizes the product and requires companies to fix their prices for the forthcoming six months. Each year the CPF distributes a list of all approved companies, products and prices, from which annuitants may choose. In the absence of much product differentiation and in the presence of complete information, there is little opportunity for marketing and sales commissions. This may explain why the MWR is higher than that in most other countries.

A similar amount may be saved on sales costs when group rather than individual annuities are involved. The UK may have lower sales commission because some of the policies stem from employer-sponsored plans that get quantity discounts. The low expenses and high MWR in Israel's quasi-mandatory plan may be feasible because of low marketing expenses, given the group plans stemming from long-standing relationships between pension funds and unions. Group rates may help account for the better payout for "manager's insurance" in Israel, which is employer-sponsored, and for the ability of insurance companies to offer such a high return on the quasi-mandatory annuity in Switzerland that is handled through employers. Lower marketing costs also help explain why the U.S. federal government's group annuity plan for civil servants, the Thrift Saving Plan - which was contracted out to a private insurance company in a competitive bidding process--pays $4-5 \%$ per month more than an average individual would get in the retail market (Poterba and Warshawsky 2000). Other countries that are planning to use annuitization in their funded retirement savings plans may learn from these examples how to keep costs low. The chief reduction can come by reducing marketing costs through standardized information and group plans. This can potentially increase the MWR by 4-5\%. 


\section{Investment Portfolios and Returns of Annuity Companies}

How do insurance companies cover their costs--which range from $7-12 \%$ of premiums--if the MWR to consumers is in the vicinity of $100 \%$ or even more? Some analysts argue that a MWR equal to or greater than $100 \%$ is implausible, because of administrative costs (Poterba and Warshawsky 2000). We argue that it is plausible because companies cover their costs and profits on the spread between the risk-free rate on which our calculations of the high MWR are based, and the higher rate they earn on a riskier portfolio. The insurance company takes the entire premium paid by the annuitants, subtracts the sales commission and other up-front expenses, and invests the rest. The company gives the annuitant a fixed payment and keeps the residual of investment earnings. As more than one insurance industry expert has expressed to us: this is a spread business. Indeed, in a competitive environment, as investment earnings rise, payouts and MWR's measured by the risk-free rate will also rise, sometimes surpassing 100\%, while still leaving a spread large enough to cover costs. However, the higher spread comes at the expense of a riskier portfolio, including higher default risk and reinvestment risk. This raises questions about the safety of the funds, the need for careful regulations and whether the risk-free rate is appropriate for discounting.

Anecdotal evidence supports this view. For example, if one peruses the annual financial statements of life insurance companies such as Metlife or Swisslife, one finds that income from investment earnings is almost as large as income from premiums and far exceeds operating expenses. A recent analysis of the financial conglomerate Berkshire Hathaway, pointed out that its large insurance business made losses (in the sense that claims exceeded premiums) in 2000, but earnings on invested premiums more than offset this loss so on balance Berkshire Hathaway made a profit. Part of its insurance losses were due to the fact that its competitor, State Farm, was able to absorb even larger insurance losses without raising its rates, because of its huge net worth on which it earned investment profits. Warren Buffett, the CEO of Berkshire Hathaway, referred to the "float" as central to his business strategy (Treaster 2001). The short term "float" for property and casualty insurance becomes a "spread" on the medium and long term investments of annuity 
companies. Table 9 showed that a spread of $1.4 \%$ per year is equivalent to a load of $10-12 \%$ of the initial premium, large enough to cover administrative costs.

We have tried to estimate this spread for some of the countries in our sample. Unfortunately we do not have data on the investment portfolios of the annuity business alone since this business is usually merged with other insurance business, especially life business. While implicitly insurance companies may have separate portfolios for life and annuities as they carry out their asset-liability analyses, explicitly these portfolios are rarely separated. Moreover, the life business usually dominates, although annuities have been a growing share in many countries. The few companies that concentrate their business on annuities may not be typical of others in mixed business that offers annuities. Furthermore, most of the assets attributed to "annuities" in countries such as the US, Canada and Australia are actually in the accumulation phase, as tax advantaged retirement saving, and may never become payouts offering longevity insurance-which is our definition of annuities. Thus we can observe, at best, only an imperfect proxy for the portfolios that actually back the annuity-as-longevity-insurance business.

With these strong caveats in mind, we present in Table 13 a summary of the investment portfolios of life insurance companies in a number of countries, over time. We see there that fixed interest securities almost invariably exceed $50 \%$ of the portfolio, due in part to regulations that require this or impose heavy risk reserve requirements if a large proportion of other assets are chosen. However, we also see that public bonds are generally less than half of this amount, with most of the fixed interest portfolio invested in corporate bonds, mortgages, and loans. In the US and perhaps elsewhere the quality of bonds has been falling, due to competitive pressures to obtain a higher yield and allow product prices to improve. Junk (non-investment-grade) bonds and private placements of securities not registered with the SEC are the fastest growing categories (Townsend 1998 and 2000). One of the most striking uniformities across countries is the increasing allocation to equities over time. This now exceeds $25 \%$ in most industrialized countries in our sample. The equity share is particularly high in segregated and unit-linked portfolios backing variable annuity products in which consumers bear some of the investment risk; many of these are in the accumulation phase (see US, Canada and Australia). Non-segregated and non-unit-linked 
portfolios in Canada, Australia and the US, which have lower equity shares than the life industry as a whole, may be more representative of assets backing annuities.

Given the long-term nature of annuities and the investments which back them, it is not appropriate to use a snapshot picture of returns, which may be especially high or low in a particular year. Instead, we use data on annual returns by asset class over a longer time period, 1967-95, and apply them to the most recent investment portfolios (1998 or 1999) taken from Table 12. ${ }^{24}$ This is a conservative estimate of long run returns, as the shorter period from 1980-95 yields much higher rates due to rising stock markets and falling inflation over this period (Davis 2001). Where the breakdown into public and private bonds is not available, we impute $50 \%$ of the bonds as public, although the actual proportion is lower in most cases where we have the breakdown.

Table 13 presents the excess real return over the government bonds rate for the life insurance industry in these five countries. Panle A applies own-country returns by asset class and Panel B applies the average returns for 12 OECD countries; the picture is very similar. This shows what the spread would be if insurance companies maintained their current portfolios and earned the long term historical returns on these portfolios. The spread varies between 1.6 and 4\%, with most of it coming from mortgages and equities. Investments implicitly backing the fixed annuity business in "general" accounts have a somewhat lower spread, but one which nonetheless exceeds $1.3 \%$ in virtually all countries. This is enough to cover costs as calculated in the previous section, while still allowing a payout whose expected present value equals the total premium (MWR close to 100\%), consistent with our data in Tables 6 and 7.

Besides earning the equity and mortgage premium, part of these gains are made by strategic choice of duration of bonds, which does not show up in this table. When discounting by the term structure, we are implicitly assuming that short-term investments must be made to cover payouts that are due in the near future. This may be true for an individual financing her own retirement. However, an insurance company has an intergenerational life and therefore has the opportunity to engage in inter-generational exchanges - using net cash inflows from new business and from maturing old investments, as well as current interest and dividends, to finance near-term payouts, while investing the remaining money in long term securities. This reduces reinvestment risk and raises the 
average return if the yield curve is rising. Indeed, discussions with people in the industry suggest that most of the bonds are long term. This is an especially valuable strategy in countries such as Switzerland and Singapore, which had very steep yield curves at the time we carried out our quantitative analyses. Companies in these countries were able to earn long-term rates while meeting short run obligations. Long term bonds are more risky in the sense that their prices are more sensitive to interest rate change. However, life insurance companies with a cash inflow from other sources can adopt a "buy and hold" strategy that makes them less vulnerable to this risk. The spread they earn between the short and longterm rates can then help to cover their costs and finance a high MWR. 5

The fact that equity returns in the US over the last two decades have been rising and have far exceeded the long term returns we used in these calculations may be one explanation for the rising MWR observed by analysts (Brown, Mitchell and Poterba 2000). This approach also helps explain why, in the UK, the MWR of price-indexed annuities is substantially lower than that of nominal annuities in the UK or elsewhere, while this is not true of indexed annuities in Chile. The chief explanation for the higher load associated with indexed annuities in the UK is probably not selection, as escalating annuities in the UK, which should produce the same selection, have a much higher MWR. Rather, the explanation may stem from differential access to the spread between the risk-free and risky rates. Companies offering price-indexed annuities in countries where most financial instruments are not price-indexed have less access to the spread. In such countries only government bonds are indexed and usually for short or medium terms. To earn the equity premium or the higher yield from long term corporate bonds or mortgages these companies must bear inflation risk, for which they will charge consumers. If, in contrast, they decide to invest mainly in indexed government bonds to avoid inflation risk, they lose the opportunity to earn a higher return on their portfolio, and must charge consumers explicitly for their administrative and equity costs. In either case, the MWR will be significantly lower, as we have seen. Companies in the UK that offer escalating annuities do not face this trade-off, as their liability is not subject to the same uncertainty, so they can offer a higher return to annuitants. Similarly, in countries where a broader range of indexed instruments are available, as in Chile, this trade-off does not arise and companies can offer price-indexed annuities with a lower risk and load. 
If insurance companies invest in a risky portfolio, how can they sell the resulting annuities as "risk-free?" Should a higher discount rate be used, in view of the risky underlying portfolio? The company turns the risky investments that it makes into "safe" or "safer" annuities by reducing over-all risk and shifting the remaining risk to others besides its annuity consumers. It reduces risk (compared with the total risk of numerous small investors) by:

- investment diversification in a large portfolio, including foreign diversification;

- applying expertise to use derivatives and other hedging techniques;

- sharing risk across several different product lines, including life insurance and annuities whose risk is negatively correlated;

- better access to information or lower information costs relative to assets;

- using its continual cash inflow to provide liquidity and make it less vulnerable to market timing risk.

It shifts risk by:

- reinsurance (though this has rarely been used for annuities);

- resort to annuity guarantee pools, especially in quasi-mandatory situations;

- risk-sharing and cross-subsidization among annuitants of different cohorts or consumers of different products - this works if competition is imperfect, demand is inelastic for other products and annuities are only a small part of the total business;

- using stockholders as residual claimants whose profits (negative or positive) buffer and smooth unexpected events;

- and by bankruptcy laws that give annuitants and other policy-holders high priority in such cases.

It is sometimes argued that mandatory retirement accumulations should be annuitized through a public agency, which would be best able to reduce risk by widespread pooling and to guarantee the promised amounts to beneficiaries by shifting risk to society at large. However, public annuity providers would have less access to the other risk-reducing and risk-shifting techniques that private companies use, including the insurance of risks that are negatively correlated, investment in diversified portfolios, reinsurance, use of shareholders as buffers and protective bankruptcy laws. The combination of these arrangements reduces risk and shifts risk away from fixed rate annuitants, toward others who are more willing to 
bear it. The spread between the interest rate paid to annuitants and earned on the underlying investment portfolios is a measure of the risk and term intermediation provided by insurance companies. It is large enough to cover the companies' administrative costs and yield an MWR close to $100 \%$ in our sample of countries. A public provider with limited investment options would not be able to cover its costs by these means and would have to charge an explicit load instead.

\section{Conclusion}

We have found that, despite their undeveloped state, annuities markets operate in ways that are systematic and compatible with competition in the 8 countries in our sample. Annuity consumers respond to incentives and constraints imposed by public policy. Monthly payouts for a given premium vary widely, but these differences are not random. In fact, our analysis indicates that monthly payout differences across countries are largely dictated by interest rate differentials and tend to equate lifetime payouts and MWR's. In most cases MWR's for annuitants range between 97 and 106\%, using the risk-free discount rate. The margin below the risk-free rate is less than 30 basis points of assets per year and sometimes it is negative. These numbers are consistent with those found in earlier studies for the US and UK but they seem to prevail in many other countries.

As expected, we found:

1) differential interest rates lead to wide variation in monthly payouts but similar discounted lifetime payouts, holding mortality rates constant across countries;

2) differences in mortality rates and projected improvement factors help explain the smaller differences in expected lifetime payouts and measured MWR, especially for outliers such as Switzerland and Israel.

3) monthly payouts differ but MWR's are similar across most annuity products and both genders - once the time pattern of payments is taken into account;

4) the one exception is price-indexed annuities, which have a lower MWR than nominal annuities in the UK (but this does not appear to be true in Chile);

5) differences in apparent selection effects across countries and products are roughly consistent with a priori expectations and are small in many cases. 
The key role played by interest rates in explaining monthly payouts is reassuring. Outliers in expected lifetime payouts must be viewed with caution, given the uncertainty and subjectivity concerning mortality projections.

The chief puzzle we confronted at the beginning was: how can insurance companies cover their costs, profits and risks if they offer MWR's exceeding 97\%? We hypothesized that these companies act as institutions for risk and term intermediation and earn a spread in the process. They invest in diversified portfolios that earn a risk premium, then engage in risk-reducing and risk-shifting activities that turn these returns into safe or safer annuities that they sell to annuitants at the risk-free rate. They cover their costs on the spread between the risk-free and risky rate and between the term structure of interest rates and the longer term rates in which they invest. This perspective helps explain why indexed annuities are more expensive than nominal annuities and raises serious questions about whether indexed annuities should be required for Pillar II disbursements in countries where few long term indexed instruments are available. It also provides a possible insight into why MWR's seem to be rising over the past two decades in the US, as equity returns have escalated. Our data indicate that administrative costs, including primarily marketing costs, are $7-8 \%$ of premiums, or $10-12 \%$ when risk premium and opportunity cost of equity capital are added. This is equivalent to $1.2-1.5 \%$ of assets per year. At the same time, life insurance companies earn $1.6-4 \%$ of assets per year above the risk-free rate; the general accounts that back annuities earn a somewhat smaller spread but one which nonetheless exceeds $1.3 \%$. This spread is enough to cover their costs, as well as profits. In the face of this large revenue from investing annuitant premiums, competition keeps the direct load very low, in some cases negative. Thus, the high MWR's are quite compatible with insurance company supply behavior.

We return to the second question we posed at the beginning: How can we reconcile these numbers with consumer behavior? Why are annuity purchases so small despite these apparently high MWR's? Part of the answer lies in the fact that the MWR for the individual annuity is $6-12 \%$ lower for the average population member than for the average annuitantdue to some combination of active and passive selection. But if lifetime consumption smoothing were the major objective of consumers, this load factor caused by selection probably would not be enough to cause the demand for annuities to disappear. Moreover, 
this MWR difference is substantially reduced for joint and period certain annuities. Additionally, for other insurance products, insurance companies have learned to invest in information that allows them to place different consumers into different risk categories, thereby counteracting adverse selection due to asymmetric information. That they do not do so for annuities suggests that they do not see a potential market there, even when asymmetric information is removed. Crowd-out of voluntary annuitization by public and private defined benefit plans is part of the explanation. Annuity purchases are larger and selection smaller in quasi-mandatory than in voluntary markets and in countries where the public benefits are less important, suggesting that annuitization will increase further as DB plans decline and mandatory retirement savings accounts become a more common part of social security systems.

Possibly more important, the MWR is $10-12 \%$ lower when a risky discount rate is used; so it is important to determine which rate is relevant to potential annuitants making their decisions. For those who want a very safe product, discounting at the risk-free rate (or something close to it) may be appropriate and annuities in their present form may be a good deal. But for those who prefer a risky investment with a correspondingly higher return, the risky rate may be appropriate. This includes, in particular, individuals with other savings that are largely invested in risky assets, indicating a preference for a higher risk-return trade-off. Similarly, for people who are liquidity constrained a higher subjective discount rate may be appropriate. This includes those who are already borrowing at high rates of interest that constitutes their discount rate. It also includes those with meager accumulations who would prefer greater flexibility in access to their savings to meet unforeseen contingencies; purchasing an annuity that yields a rigid income stream takes away the precautionary function of their savings and introduces new risks for them.

These two groups - the risk-preferring and the liquidity constrained--may comprise a large share of the potential market. They may not purchase annuities despite the apparently high MWR's we have calculated, because they are applying a different discount rate that yields a lower MWR. To attract these groups into the voluntary annuity market, or to give them a good deal in the quasi-mandatory market, may require the development of annuity products that share the inevitable investment and mortality risk (and return) between the company and its consumers and/or that offer greater flexibility in the time 
stream of withdrawals. This would provide other benefits from saving that consumers value, but at the expense of pure longevity insurance. It would pose principal-agent and informational problems, additional costs and regulatory burdens. We investigate these risksharing and flexibility arrangements and regulatory issues in a sequel to this paper. 
Table 1: Size and Recent Growth of Annuity Industry in Several Sample Countries Life Insurance and Annuities

\begin{tabular}{|c|c|c|c|c|c|c|}
\hline & 1980 & 1990 & 1992 & 1995 & 1997 & 1999 \\
\hline \multicolumn{7}{|l|}{ Canada (in billions Canada \$) } \\
\hline \multicolumn{7}{|l|}{ Annuity premium } \\
\hline Total & 3.3 & 11.9 & 12.9 & 12.9 & 17.0 & 20.0 \\
\hline$\%$ individual & $54.5 \%$ & $61.3 \%$ & $56.6 \%$ & $55.8 \%$ & $58.2 \%$ & $55.5 \%$ \\
\hline$\%$ in payout stage (within individual) & & & & & $29.0 \%$ & $19.0 \%$ \\
\hline$\%$ in payout stage (within group) & & & & & $15.0 \%$ & $11.0 \%$ \\
\hline $\begin{array}{l}\% \text { in payout stage with longevity insurance } \\
\text { (life annuities, within individual) }\end{array}$ & & & & & $30.5 \%$ & $31.1 \%$ \\
\hline \multicolumn{7}{|l|}{ Life insurance premium } \\
\hline Total & 3.3 & 6.7 & 7.5 & 8.5 & 9.6 & 10.5 \\
\hline$\%$ individual & $69.7 \%$ & $71.6 \%$ & $74.7 \%$ & $75.3 \%$ & $76.0 \%$ & $77.1 \%$ \\
\hline \multicolumn{7}{|l|}{ Ratios } \\
\hline Annuity premium / Life premium & $100 \%$ & $177.6 \%$ & $172.0 \%$ & $151.8 \%$ & $177.1 \%$ & $190.5 \%$ \\
\hline Payout annuity premium / Life premium & & & & & $41.6 \%$ & $29.5 \%$ \\
\hline Life payout annuities/Life premiums (indiv.) & & & & & $12.7 \%$ & $9.2 \%$ \\
\hline \multicolumn{7}{|l|}{ US (in billions US\$'s) } \\
\hline \multicolumn{7}{|l|}{ Annuity premium } \\
\hline Total & 22.429 & 129.064 & 132.645 & 159.935 & 197.547 & 270.212 \\
\hline$\%$ individual & $28.1 \%$ & $41.6 \%$ & $46.2 \%$ & $48.4 \%$ & $45.7 \%$ & $42.8 \%$ \\
\hline$\%$ in payout stage (individual) & & & & & & $6.0 \%$ \\
\hline$\%$ in payout stage (group) & & & & & & $23.5 \%$ \\
\hline \multicolumn{7}{|l|}{ Life insurance premium } \\
\hline Total & 40.829 & 76.692 & 83.868 & 102.766 & 115.039 & 120.274 \\
\hline$\%$ individual & $75.4 \%$ & $79.0 \%$ & $79.0 \%$ & $76.4 \%$ & $76.0 \%$ & $77.6 \%$ \\
\hline$\%$ new (within individual) & $11.1 \%$ & $14.7 \%$ & $13.3 \%$ & $11.8 \%$ & $12.7 \%$ & $14.0 \%$ \\
\hline \multicolumn{7}{|l|}{ Ratios } \\
\hline Annuity premium / Life premium & $54.9 \%$ & $168.3 \%$ & $158.2 \%$ & $155.6 \%$ & $171.7 \%$ & $224.7 \%$ \\
\hline Payout annuity premium / Life premium & & & & & & $36.0 \%$ \\
\hline Payout annuity/Life premium (individual) & & & & & & $7.4 \%$ \\
\hline Payout annuity/New life premium (indiv.) & & & & & & $41.4 \%$ \\
\hline \multicolumn{7}{|l|}{ UK (in billions UK pounds) } \\
\hline Annuity - new single premium & & & 3.4 & 3.5 & 4.7 & \\
\hline Life insurance premium & & & & & 41.2 & \\
\hline Annuity premium / Life premium & & & & & $11.4 \%$ & \\
\hline Singapore (in Singapore \$) & 1988 & & & & & \\
\hline \multicolumn{7}{|l|}{ Annuity premium } \\
\hline Total $(\mathrm{S} \$ \mathrm{M})$ & 17.4 & 12.6 & 43.2 & 74.5 & 104.2 & \\
\hline Premium / Contract (S 1000\$) & 31.0 & 32.8 & 32.5 & 37.9 & 40.9 & \\
\hline \multicolumn{7}{|l|}{ Life insurance premium } \\
\hline New - Total (S\$M) & 188.6 & 267.9 & 370.9 & 559.5 & 804.8 & \\
\hline New--Premium / Contract (S 1000\$) & 1.0 & 1.1 & 1.1 & 1.3 & 1.8 & \\
\hline In force - Total $(\mathrm{S} \$ \mathrm{M})$ & 659.2 & $1,070.8$ & $1,629.9$ & $2,928.5$ & $4,093.2$ & \\
\hline In force -- Premium / Contract (S 1000\$) & 0.9 & 1.0 & 1.1 & 1.2 & 1.3 & \\
\hline \multicolumn{7}{|l|}{ Ratios } \\
\hline Annuity premium / Life premium & $2.1 \%$ & $0.9 \%$ & $2.2 \%$ & $2.1 \%$ & $2.1 \%$ & \\
\hline Annuity premium / New life premium & $9.2 \%$ & $4.7 \%$ & $11.6 \%$ & $13.3 \%$ & $12.9 \%$ & \\
\hline
\end{tabular}




\begin{tabular}{|l|l|l|l|l|l|}
\hline & $\mathbf{1 9 9 1}$ & $\mathbf{1 9 9 2}$ & $\mathbf{1 9 9 5}$ & $\mathbf{1 9 9 7}$ & $\mathbf{1 9 9 8}$ \\
\hline Chile (in millions US\$) & & & & & \\
\hline Annuity premium & 598 & 650 & 979 & 1,161 & 1,103 \\
\hline Life insurance premium & 268 & 291 & 378 & 515 & 605 \\
\hline Annuity premium / Life premium & $223.1 \%$ & $223.4 \%$ & $259.0 \%$ & $225.4 \%$ & $182.3 \%$ \\
\hline Australia (in billions Australia \$) & & 1994 & 1995 & 1997 & 1998 \\
\hline Annuity market & & & & & \\
\hline Total assets backing annuity products & & 10.3 & 12.3 & 20.0 & 24.7 \\
\hline \% in payout stage & & $44.2 \%$ & $46.7 \%$ & $41.5 \%$ & $38.2 \%$ \\
\hline \% in payout stage that are life annuities & & $29.6 \%$ & $26.3 \%$ & $28.4 \%$ & $31.7 \%$ \\
\hline Assets in life insurance excl. annuity & & 90.0 & 95.5 & 131.8 & 135.3 \\
\hline Ratios & & & & & \\
\hline Annuity assets / Life assets & & $11.4 \%$ & $12.9 \%$ & $15.2 \%$ & $18.3 \%$ \\
\hline Payout annuity assets/Life assets & & $5.0 \%$ & $6.0 \%$ & $6.3 \%$ & $7.0 \%$ \\
\hline Life payout annuity assets/Life assets & & $1.5 \%$ & $1.6 \%$ & $1.8 \%$ & $2.2 \%$ \\
\hline
\end{tabular}

Footnote: For Chile, most annuities are in payout stage and for Singapore most are deferred annuities with payouts beginning 7 years after purchase, so distinction between payout and accumulation is not given. Most of the payout annuities in these two countries are life annuities - joint annuities in Chile, $15 \mathrm{YG}$ in Singapore - as a result of regulatory requirements.

Sources:

Canada: Office of the Superintendent of Financial Institutions, CLHIA, and Kim and Sharp (1999).

US: ACLI Life Insurers Fact Book 2000.

UK: Murthi, Orszag, and Orszag (page 9 and Figure 1, page 10).

Singapore: Chang (p5 \& 6).

Chile: annuity market survey conducted by Insurance Superintendency in 1999 cited in Callund (1999).

Australia: Knox (Table 1 \& 2) who lists his source as Rice Kachor (1999); APRA (1999). 
Table 2. Annuities and Other Payouts in Chile 1988-2000

A. Aggregate Payouts by Payout Method and Benefit Category

\begin{tabular}{|c|c|c|c|c|}
\hline & $\begin{array}{l}\text { Number of } \\
\text { policies }\end{array}$ & $\begin{array}{l}\text { Average size of } \\
\text { policy (CHS's) }\end{array}$ & $\begin{array}{l}\text { Total annual amount } \\
\text { (CHS millions) }\end{array}$ & $\begin{array}{l}\text { \% within category } \\
\text { (total annual amount) }\end{array}$ \\
\hline \multicolumn{5}{|r|}{ (20) } \\
\hline Old Age Normal & 11,818 & 67,101 & 793.00 & \\
\hline Annuity & 3,433 & 118,748 & 407.66 & $51.4 \%$ \\
\hline Gradual withdraw & 8,385 & 45,947 & 385.27 & $48.6 \%$ \\
\hline Other & NA & 144,515 & 0.14 & $0.0 \%$ \\
\hline Early Retirement & 771 & 147,067 & 113.39 & \\
\hline Annuity & 766 & 146,378 & 112.13 & $98.9 \%$ \\
\hline Gradual withdraw & 5 & 200,552 & 1.00 & $0.9 \%$ \\
\hline Other & NA & 407,313 & 0.41 & $0.4 \%$ \\
\hline Disability\& Survivor & 43,774 & 65,939 & $2,886.40$ & \\
\hline Annuity & 1,443 & 91,973 & 132.2 & $4.6 \%$ \\
\hline Gradual withdraw & 9,744 & 35,763 & 348.47 & $12.1 \%$ \\
\hline Other & 32,587 & 73,813 & $2,405.33$ & $83.3 \%$ \\
\hline Grand Total & 56,363 & 67,298 & $3,793.13$ & \\
\hline Annuity & 5,642 & 115,651 & 652.50 & $17.2 \%$ \\
\hline Gradual withdraw & 18,134 & 40,517 & 734.74 & $19.4 \%$ \\
\hline Other & 32,587 & 73,830 & $2,405.89$ & $63.4 \%$ \\
\hline \multicolumn{5}{|l|}{1993} \\
\hline Old Age Normal & 43,089 & 89,331 & $3,849.18$ & \\
\hline Annuity & 11,529 & 121,879 & $1,405.14$ & $36.5 \%$ \\
\hline Gradual withdraw & 30,868 & 71,321 & $2,201.54$ & $57.2 \%$ \\
\hline Other & 692 & 350,423 & 242.49 & $6.3 \%$ \\
\hline Early Retirement & 37,521 & 154,515 & $5,797.56$ & \\
\hline Annuity & 33,127 & 133,608 & $4,426.03$ & $76.3 \%$ \\
\hline Gradual withdraw & 2,288 & 232,981 & 533.06 & $9.2 \%$ \\
\hline Other & 2,106 & 398,129 & 838.46 & $14.5 \%$ \\
\hline Disability\& Survivor & 74,716 & 67,252 & $5,024.79$ & \\
\hline Annuity & 13,250 & 82,524 & $1,093.45$ & $21.8 \%$ \\
\hline Gradual withdraw & 35,112 & 45,580 & $1,600.41$ & $31.9 \%$ \\
\hline Other & 26,354 & 88,448 & $2,330.95$ & $46.4 \%$ \\
\hline Grand Total & 155,326 & 94,456 & $14,671.53$ & \\
\hline Annuity & 57,906 & 119,584 & $6,924.62$ & $47.2 \%$ \\
\hline Gradual withdraw & 68,268 & 63,500 & $4,335.01$ & $27.5 \%$ \\
\hline Other & 28,152 & 117,038 & $3,411.90$ & $23.3 \%$ \\
\hline \multicolumn{5}{|l|}{2000} \\
\hline Old Age Normal & 93,152 & 103,278 & $9,620.71$ & \\
\hline Annuity & 30,726 & 139,248 & $4,278.55$ & $44.5 \%$ \\
\hline Gradual withdraw & 61,678 & 81,846 & $5,048.09$ & $52.5 \%$ \\
\hline Other & 748 & 393,144 & 294.07 & $3.1 \%$ \\
\hline Early Retirement & 132,221 & 159,338 & $21,067.81$ & \\
\hline Annuity & 111,720 & 139,564 & $15,592.07$ & $74.0 \%$ \\
\hline Gradual withdraw & 15,032 & 222,671 & $3,347.19$ & $15.9 \%$ \\
\hline Other & 5,469 & 389,202 & $2,128.54$ & $10.1 \%$ \\
\hline Disability\& Survivor & 137,978 & 72,229 & $9,966.04$ & \\
\hline Annuity & 47,355 & 81,400 & $3,854.69$ & $38.7 \%$ \\
\hline Gradual withdraw & 70,822 & 56,234 & $3,982.57$ & $40.0 \%$ \\
\hline Other & 19,801 & 107,511 & $2,128.82$ & $21.4 \%$ \\
\hline Grand Total & 363,351 & 111,888 & $40,654.60$ & \\
\hline Annuity & 189,801 & 125,001 & $23,725.30$ & $58.4 \%$ \\
\hline Gradual withdraw & 147,532 & 83,900 & $12,377.86$ & $30.4 \%$ \\
\hline Other & 26,018 & 174,934 & $4,551.44$ & $11.2 \%$ \\
\hline
\end{tabular}




\section{B. Payouts by Type of Benefit}

\begin{tabular}{|l|c|c|c|c|c|c|}
\hline & $\begin{array}{l}\text { \%of total } \\
\text { recipients }\end{array}$ & $\begin{array}{l}\text { \% of total } \\
\text { payout }\end{array}$ & $\begin{array}{l}\text { \% of total } \\
\text { recipients }\end{array}$ & $\begin{array}{l}\text { \% of total } \\
\text { payout }\end{array}$ & $\begin{array}{l}\text { \%of total } \\
\text { recipients }\end{array}$ & $\begin{array}{l}\text { \% of total } \\
\text { payout }\end{array}$ \\
\cline { 2 - 7 } & \multicolumn{3}{|c|}{1988} & \multicolumn{2}{c|}{1990} & \multicolumn{2}{c|}{1993} \\
\hline Old Age Normal & 21.0 & 20.9 & 27.4 & 28.2 & 27.7 & 26.2 \\
\hline Early Retirement & 1.4 & 3.0 & 6.7 & 12.1 & 24.2 & 39.5 \\
\hline Disability \& Survivor & 77.7 & 76.1 & 65.9 & 59.7 & 48.1 & 34.2 \\
\hline & \multicolumn{3}{|c|}{1996} & \multicolumn{2}{|c|}{2000} \\
\hline Old Age Normal & 25.7 & 23.2 & 24.5 & 22.6 & 25.6 & 23.7 \\
\hline Early Retirement & 33.8 & 50.6 & 36.6 & 52.0 & 36.4 & 51.8 \\
\hline Disability \& Survivor & 40.5 & 26.2 & 38.9 & 25.4 & 38.0 & 24.5 \\
\hline
\end{tabular}

\section{Payout Methods - Annuity, Gradual Withdrawal, and Other}

\begin{tabular}{|c|c|c|c|c|c|c|}
\hline & $\begin{array}{l}\text { \% of } \\
\text { recipients } \\
\text { within } \\
\text { category }\end{array}$ & $\begin{array}{l}\text { \% amount } \\
\text { within } \\
\text { category }\end{array}$ & $\begin{array}{l}\text { \% of } \\
\text { recipients } \\
\text { within } \\
\text { category }\end{array}$ & $\begin{array}{l}\text { \% amount } \\
\text { within } \\
\text { category }\end{array}$ & $\begin{array}{l}\text { \% of } \\
\text { recipients } \\
\text { within } \\
\text { category }\end{array}$ & $\begin{array}{l}\text { \% amount } \\
\text { within } \\
\text { category }\end{array}$ \\
\hline & \multicolumn{2}{|c|}{1988} & \multicolumn{2}{|c|}{1990} & \multicolumn{2}{|c|}{1993} \\
\hline \multicolumn{7}{|l|}{ Old Age Normal } \\
\hline Annuity & 29.0 & 51.4 & 29.2 & 49.4 & 26.8 & 36.5 \\
\hline Gradual withdraw & 71.0 & 48.6 & 70.6 & 49.2 & 71.6 & 57.2 \\
\hline Other & NA & 0.0 & 0.2 & 1.4 & 1.6 & 6.3 \\
\hline \multicolumn{7}{|l|}{ Early Retirement } \\
\hline Annuity & 99.4 & 98.9 & 98.7 & 96.6 & 88.3 & 76.3 \\
\hline Gradual withdraw & 0.6 & 0.9 & 0.7 & 1.5 & 6.1 & 9.2 \\
\hline Other & NA & 0.4 & 0.6 & 1.9 & 5.6 & 14.5 \\
\hline \multicolumn{7}{|l|}{ Disability \& Survivor } \\
\hline Annuity & 3.3 & 4.6 & 13.2 & 18.5 & 17.7 & 21.8 \\
\hline Gradual withdraw & 22.3 & 12.1 & 34.5 & 19.2 & 47.0 & 31.9 \\
\hline Other & 74.4 & 83.3 & 52.3 & 62.3 & 35.3 & 46.4 \\
\hline \multicolumn{7}{|l|}{ All Benefit Types } \\
\hline Annuity & 10.0 & 17.2 & 23.3 & 36.7 & 37.3 & 47.2 \\
\hline Gradual withdraw & 32.2 & 19.4 & 42.1 & 25.5 & 44.0 & 29.5 \\
\hline \multirow[t]{2}{*}{ Other } & 57.8 & 63.4 & 34.6 & 37.9 & 18.8 & 23.3 \\
\hline & \multicolumn{2}{|c|}{1996} & \multicolumn{2}{|c|}{1998} & \multicolumn{2}{|c|}{2000} \\
\hline \multicolumn{7}{|l|}{ Old Age Normal } \\
\hline Annuity & 27.3 & 37.4 & 30.6 & 43.6 & 33.0 & 44.5 \\
\hline Gradual withdraw & 71.1 & 57.2 & 68.2 & 52.1 & 66.2 & 52.5 \\
\hline Other & 1.6 & 5.4 & 1.3 & 4.3 & 0.8 & 3.1 \\
\hline \multicolumn{7}{|l|}{ Early Retirement } \\
\hline Annuity & 79.2 & 64.6 & 85.1 & 77.3 & 84.5 & 74.0 \\
\hline Gradual withdraw & 13.4 & 17.8 & 11.3 & 13.2 & 11.4 & 15.9 \\
\hline Other & 7.4 & 17.6 & 3.6 & 9.5 & 4.1 & 10.1 \\
\hline \multicolumn{7}{|c|}{ Disability \& Survivor } \\
\hline Annuity & 22.3 & 26.1 & 30.2 & 34.4 & 34.3 & 38.7 \\
\hline Gradual withdraw & 53.3 & 38.9 & 50.5 & 37.1 & 51.3 & 40.0 \\
\hline Other & 24.4 & 35.0 & 19.3 & 28.5 & 14.4 & 21.4 \\
\hline \multicolumn{7}{|l|}{ All Benefit Types } \\
\hline Annuity & 42.8 & 48.2 & 50.4 & 58.8 & 52.2 & 58.4 \\
\hline Gradual withdraw & 44.4 & 32.4 & 40.5 & 28.1 & 40.6 & 30.4 \\
\hline Other & 12.8 & 19.3 & 9.1 & 13.1 & 7.2 & 11.2 \\
\hline
\end{tabular}




\begin{tabular}{|c|c|c|c|c|c|c|}
\hline & $\begin{array}{l}\text { \% of } \\
\text { recipients } \\
\text { within } \\
\text { category }\end{array}$ & $\begin{array}{l}\text { \% amount } \\
\text { within } \\
\text { category }\end{array}$ & $\begin{array}{l}\% \text { of } \\
\text { recipients } \\
\text { within } \\
\text { category } \\
\end{array}$ & $\begin{array}{l}\text { \% amount } \\
\text { within } \\
\text { category }\end{array}$ & $\begin{array}{l}\text { \% of } \\
\text { recipients } \\
\text { within } \\
\text { category }\end{array}$ & $\begin{array}{l}\text { \% amount } \\
\text { within } \\
\text { category }\end{array}$ \\
\hline & \multicolumn{2}{|c|}{1988} & \multicolumn{2}{|c|}{1990} & \multicolumn{2}{|c|}{1993} \\
\hline \multicolumn{7}{|l|}{ Annuity } \\
\hline Old Age Normal & 60.8 & 62.5 & 34.4 & 38.0 & 19.9 & 20.3 \\
\hline Early Retirement & 13.6 & 17.2 & 28.2 & 32.0 & 57.2 & 63.9 \\
\hline Disability \& Survivor & 25.6 & 20.3 & 37.4 & 30.0 & 22.9 & 15.8 \\
\hline \multicolumn{7}{|l|}{ Gradual Withdraw } \\
\hline Old Age Normal & 46.2 & 52.4 & 45.9 & 54.4 & 45.2 & 50.8 \\
\hline Early Retirement & 0.0 & 0.1 & 0.1 & 0.7 & 3.4 & 12.3 \\
\hline Disability \& Survivor & 53.7 & 47.4 & 54.0 & 44.9 & 51.4 & 36.9 \\
\hline \multicolumn{7}{|l|}{ Other } \\
\hline Old Age Normal & 0.0 & 0.0 & 0.2 & 1.1 & 2.4 & 7.2 \\
\hline Early Retirement & 0.0 & 0.0 & 0.1 & 0.6 & 7.2 & 24.6 \\
\hline \multirow[t]{2}{*}{ Disability \& Survivor } & 1.0 & 1.0 & 99.7 & 98.3 & 90.4 & 68.3 \\
\hline & \multicolumn{2}{|c|}{1996} & \multicolumn{2}{|c|}{1998} & \multicolumn{2}{|c|}{2000} \\
\hline \multicolumn{7}{|l|}{ Annuity } \\
\hline Old Age Normal & 16.4 & 18.0 & 14.9 & 16.8 & 16.2 & 18.0 \\
\hline Early Retirement & 62.5 & 67.8 & 61.8 & 68.4 & 58.9 & 65.7 \\
\hline Disability \& Survivor & 21.1 & 14.2 & 23.3 & 14.9 & 24.9 & 16.2 \\
\hline \multicolumn{7}{|l|}{ Gradual Withdraw } \\
\hline Old Age Normal & 41.2 & 40.9 & 41.3 & 41.9 & 41.8 & 40.8 \\
\hline Early Retirement & 10.2 & 27.8 & 10.2 & 24.5 & 10.2 & 27.0 \\
\hline Disability \& Survivor & 48.6 & 31.4 & 48.5 & 33.6 & 48.0 & 32.2 \\
\hline \multicolumn{7}{|l|}{ Other } \\
\hline Old Age Normal & 3.2 & 6.5 & 3.4 & 7.4 & 2.9 & 6.5 \\
\hline Early Retirement & 19.5 & 46.0 & 14.3 & 37.5 & 21.0 & 46.8 \\
\hline Disability \& Survivor & 77.3 & 47.5 & 82.3 & 55.1 & 76.1 & 46.8 \\
\hline
\end{tabular}

Source: Augusto Iglesias from PrimAmerica's database. 
Table 3: Monthly Annuity Pay-Outs for Immediate Annuities at Age 65

( $\$ 100,000$ premium, paid in spring 1999)

\section{A. Male-Nominal}

\begin{tabular}{|l|l|l|l|l|l|l|}
\hline & Canada & US & Australia & UK & Switzerland & Singapore \\
\hline Level SPIA $^{1}$ & 740 & 733 & 700 & 727 & 590 & \\
\hline $1^{2} \mathrm{YG}^{2}$ & 702 & & 658 & 691 & 571 & 650 \\
\hline Joint SPIA $^{3}$ & 664 & 648 & 543 & 642 & $501(600)$ & \\
\hline Escalating SPIA $^{4}$ & & & & 564 & & \\
\hline
\end{tabular}

B. Male-Price Indexed

\begin{tabular}{|l|l|l|l|l|l|}
\hline & \multirow{2}{*}{ UK } & \multirow{2}{*}{ Chile } & \multicolumn{2}{|l|}{ Israel $^{\mathbf{5}}$} \\
\cline { 4 - 6 } & & & $\begin{array}{l}\text { Immediate } \\
\text { annuity }\end{array}$ & $\begin{array}{l}\text { Managers } \\
\text { insurance }\end{array}$ & $\begin{array}{l}\text { Deferred } \\
\text { annuity }\end{array}$ \\
\hline Level SPIA & 522 & 820 & 625 & 642 & \\
\hline 10YG & & 761 & 584 & 600 & \\
\hline Joint SPIA & 438 & 731 & & & $(663)$ \\
\hline
\end{tabular}

\section{Female-Nominal}

\begin{tabular}{|l|l|l|l|l|l|l|}
\hline & Canada & US & Australia & UK & Switzerland & Singapore \\
\hline Level SPIA & 662 & 662 & 621 & 640 & 526 & \\
\hline 10YG & 644 & & 599 & 626 & 519 & 607 \\
\hline Escalating SPIA & & & & 475 & & \\
\hline
\end{tabular}

\section{Female-Price Indexed}

\begin{tabular}{|l|l|l|l|l|}
\hline & UK & Chile & \multicolumn{2}{|l|}{ Israel } \\
\cline { 4 - 5 } & & $\begin{array}{l}\text { Immediate } \\
\text { annuity }\end{array}$ & $\begin{array}{l}\text { Managers } \\
\text { insurance }\end{array}$ \\
\hline Level SPIA & 436 & 723 & 552 & 567 \\
\hline 10 YG & & 695 & 530 & 544 \\
\hline
\end{tabular}

${ }^{1}$ SPIA = single premium immediate annuity. For Switzerland a bonus that is not guaranteed but has been regularly paid for many years, is included.

2 10YG means payment continues for at least 10 years even if individual dies; beneficiary is named. For Singapore this is the payout beginning at age 62 for a premium of $\$ 73,927$ paid at age 55 that had accumulated to $\$ 100,000$ by age 62 , compounded at the 7-year bond rate, under the deferred annuity option of the Minimum Sum Scheme. It carries a 15-year guarantee. See Appendix A for further details.

${ }^{3}$ For Canada, US, UK joint annuity is based on assumption that both spouses are same age and survivor gets $50 \%$ of initial payout. For Switzerland number in parentheses is for Pillar 2--quasi-mandatory annuity that pays $\$ 600$ based on regulations that require annual payout $=7.2 \%$ of accumulation, $60 \%$ to survivor. In Chile, joint annuity pays $60 \%$ to survivor as per regulations in quasi-mandatory market (Pillar 2). For Australia husband is assumed to be 65 , wife is 60 and survivor gets $85 \%$ of initial payout. Joint annuity with female as primary beneficiary has slightly high payout but is much less common form.

${ }^{4}$ Escalating annuity means that payment increases at fixed rate per year- $3 \%$ for UK. Payout given is for initial year; in later years payout will be higher by this fixed rate.

${ }^{5}$ For Israel: immediate annuity is in voluntary market; managers insurance is employer-sponsored voluntary; number in parentheses is for quasi-mandatory deferred annuity purchased with annual contributions throughout working life. This is the payout beginning at age 65 for a premium of $\$ 1052$ in present value paid annually from age 25 to age 65 , that accumulates to $\$ 100,000$ at age 65 , compounded at the $4 \%$ net rate of return. Joint annuity with $60 \%$ to survivor is required. Payout is not binding; can be decreased if needed for actuarial solvency. See Appendix B for further details. 
$\underline{\text { Table } 4}$

Price Dispersion in the Annuity Market

Monthly Pay-Outs, Male Age 65 (SPIA)

\begin{tabular}{|l|l|l|l|l|l|l|}
\hline & Canada & US & Australia & UK & Chile & Singapore \\
\hline Top 1 & 754 & 840 & 764 & 772 & 835 & 666 \\
\hline $5^{\text {th }}$ Best & 748 & 807 & $720^{*}$ & 723 & 819 & 642 \\
\hline Average & 740 & 733 & 700 & 708 & 820 & 650 \\
\hline Worst & 723 & 638 & 626 & & 748 & 632 \\
\hline
\end{tabular}

*This is AMP price, not $5^{\text {th }}$ best.

Note: See Table 3 for definition. 
$\underline{\text { Table } 5}$

Life Expectancy at Age 65

\section{A. Male}

\begin{tabular}{|l|c|c|c|c|c|}
\hline Country & $\begin{array}{c}\text { Population } \\
\text { Period }\end{array}$ & $\begin{array}{c}\text { Population } \\
\text { Cohort }\end{array}$ & $\begin{array}{c}\text { Annuitant } \\
\text { Period }\end{array}$ & $\begin{array}{c}\text { Annuitant } \\
\text { Cohort }\end{array}$ & $\begin{array}{c}\text { Annuitant Cohort } \\
\text { MWR - Annuitant } \\
\text { Period MWR }\end{array}$ \\
\hline Canada & 80.9 & 81.8 & 83.1 & 84.1 & 2.7 \\
\hline US & 80.5 & 80.7 & 84.1 & 84.4 & 0.6 \\
\hline Australia & 80.8 & 81.9 & 84.1 & 85.4 & 3.4 \\
\hline UK & 79.1 & 80.4 & 80.9 & 82.1 & 4.1 \\
\hline Switzerland & 80.9 & 82.0 & 84.8 & 87.2 & $(7.2)$ \\
\hline Singapore & 80.1 & & $82.6)$ & $(84.4)$ & \\
\hline Chile & 79.5 & & 82.3 & & \\
\hline Israel & 78.9 & & 81.8 & & \\
\hline
\end{tabular}

\section{B. Female}

\begin{tabular}{|l|c|c|c|c|c|}
\hline Country & $\begin{array}{c}\text { Population } \\
\text { Period }\end{array}$ & $\begin{array}{c}\text { Population } \\
\text { Cohort }\end{array}$ & $\begin{array}{c}\text { Annuitant } \\
\text { Period }\end{array}$ & $\begin{array}{c}\text { Annuitant } \\
\text { Cohort }\end{array}$ & $\begin{array}{c}\text { Annuitant Cohort } \\
\text { MWR - Annuitant } \\
\text { Period MWR }\end{array}$ \\
\hline Canada & 84.9 & 86.3 & 86.4 & 88.1 & 3.0 \\
\hline US & 83.6 & 84.1 & 86.6 & 87.1 & 1.0 \\
\hline Australia & 84.5 & 85.4 & 87.5 & 88.5 & 2.3 \\
\hline UK & 82.4 & 83.9 & 84.2 & 85.4 & 3.5 \\
\hline Switzerland & 85.0 & 86.4 & 87.8 & 90.1 & 5.4 \\
\hline Singapore & 84.1 & & 85.7 & & \\
\hline Chile & 82.7 & & 85.8 & & \\
\hline Israel & 80.2 & & 84.6 & & \\
\hline
\end{tabular}

Note: Calculated by authors based on mortality tables for each country. For Switzerland, annuitant numbers are for voluntary annuitants (pillar 3) and numbers in parenthesis are for quasi-mandatory annuitants (pillar 2). Israel annuitant number is for mortality tables constructed by actuaries' committee. The difference in MWR is for level SPIA, except for Switzerland Pillar II, where it applies to the required joint annuity. Cohort numbers are not given for Singapore, Chile and Israel because they do not use cohort tables or have their own mortality improvement factors. 
Table 6

Money's Worth Ratio (MWR) with Risk-Free Interest Rate - Age 65 (as \%)

\section{A. Male-Nominal}

\begin{tabular}{|c|c|c|c|c|c|c|c|c|c|c|c|c|c|}
\hline & \multicolumn{2}{|c|}{ Canada } & \multicolumn{2}{|c|}{ US } & \multicolumn{2}{|c|}{ Australia } & \multicolumn{2}{|c|}{ UK } & \multicolumn{3}{|c|}{ Switzerland $^{2}$} & \multicolumn{2}{|c|}{ Singapore $^{3}$} \\
\hline & popul & annuit & popul & annuit & popul & annuit & popul & annuit & popul & annuit & $\begin{array}{l}\text { No } \\
\text { Bonus }\end{array}$ & popul & annuit \\
\hline Level SPIA & 91.4 & 98.1 & 85.8 & 97.4 & 91.1 & 101.0 & 91.2 & 98.3 & 91.6 & 108.2 & 99.8 & & \\
\hline $10 \mathrm{YG}$ & 92.8 & 97.4 & & & 91.5 & 99.6 & 94.4 & 99.3 & 94.5 & 108.0 & 99.6 & 99.6 & 102.4 \\
\hline Joint & 93.9 & 98.0 & 86.4 & 95.1 & 86.7 & 93.6 & 93.3 & 98.8 & $\begin{array}{c}90.2 \\
(111.0)\end{array}$ & $\begin{array}{c}101.3 \\
(119.8)\end{array}$ & 93.4 & & \\
\hline Escalating & & & & & & & 91.8 & 100.6 & & & & & \\
\hline
\end{tabular}

B. Male-Price Indexed

\begin{tabular}{|l|c|c|c|c|c|l|l|l|}
\hline \multirow{2}{*}{} & \multicolumn{2}{|c|}{ UK } & \multicolumn{2}{c|}{ Chile } & \multicolumn{5}{c|}{ Israel } \\
\cline { 2 - 8 } & popul & annuit & popul & annuit & popul & $\begin{array}{l}\text { Actuaries' } \\
\text { Committee }\end{array}$ & $\begin{array}{l}\text { Managers' } \\
\text { Insurance } \\
\text { Committee }\end{array}$ & $\begin{array}{l}\text { Deferred } \\
\text { Annuity- } \\
\text { Committee } \\
\text { (age 65 cohort) }\end{array}$ \\
\hline Level SPIA & 81.7 & 89.4 & 86.5 & 96.7 & 76.9 & 88.2 & 90.6 & \\
\hline 10YG & & & 88.7 & 95.4 & 79.7 & 87.7 & 90.1 & \\
\hline Joint & 81.8 & 88.0 & 90.5 & 98.5 & & & & $(109.2)$ \\
\hline
\end{tabular}

\section{Female-Nominal}

\begin{tabular}{|l|c|c|c|c|c|c|c|c|c|c|c|c|c|}
\hline & \multicolumn{2}{|c|}{ Canada } & \multicolumn{2}{c|}{ US } & \multicolumn{2}{c|}{ Australia } & \multicolumn{2}{c|}{ UK } & \multicolumn{3}{c|}{ Switzerland } & Singapore \\
\cline { 2 - 15 } & popul & annuit & popul & annuit & popul & annuit & popul & annuit & popul & annuit & $\begin{array}{l}\text { No } \\
\text { Bonus }\end{array}$ & popul & annuit \\
\hline Level SPIA & 95.0 & 97.6 & 87.1 & 95.4 & 91.5 & 98.4 & 92.6 & 97.4 & 96.9 & 105.7 & 97.5 & & \\
\hline 10YG & 95.5 & 97.3 & & & 91.2 & 97.2 & 94.9 & 98.7 & 98.2 & 105.7 & 97.5 & 100.8 & 103.9 \\
\hline Escalating & & & & & & & 92.5 & 98.8 & & & & & \\
\hline
\end{tabular}

D. Female-Price Indexed

\begin{tabular}{|l|c|c|c|c|c|c|c|}
\hline \multirow{2}{*}{} & \multicolumn{2}{|c|}{ UK } & \multicolumn{2}{c|}{ Chile } & \multicolumn{3}{c|}{ Israel } \\
\cline { 2 - 7 } & popul & annuit & popul & annuit & popul & $\begin{array}{l}\text { Actuaries' } \\
\text { Committee }\end{array}$ & $\begin{array}{l}\text { Managers' } \\
\text { Insurance- } \\
\text { Committee }\end{array}$ \\
\hline Level SPIA & 81.3 & 86.7 & 86.1 & 94.9 & 73.0 & 86.9 & 89.2 \\
\hline 10YG & & & 87.8 & 94.2 & 75.6 & 86.6 & 88.9 \\
\hline
\end{tabular}

${ }^{1}$ For definitions of annuity types and payouts see Table 3. Mortality tables are those in use in country (period tables in Chile, Israel, Singapore, cohort tables in others); for further details see Appendices A, B and C. Risk-free interest rate is term structure of government bond rates.

${ }^{2}$ For Switzerland we give MWR for payouts in voluntary market (Pillar 3) and use Pillar 3 mortality rates. "No bonus" column subtracts the bonus. Numbers in parentheses for joint annuity give MWR for payouts of quasimandatory annuity (Pillar 2) and use Pillar 2 mortality rates. Although insurance companies sometimes build in a safety margin, these are mortality rates without the safety margin.

${ }^{3}$ For Singapore the MWR is given for an individual who is age 55 in 1999 and buys a deferred annuity that begins at age 62. See Table 3 and Appendix A for further details.

${ }^{4}$ For annuitants in Israel we use a new table by an actuaries committee that gives a MWR about $2 \%$ higher than the legally required table. See Table 3 and Appendix B for further details. 
Table 7

Money's Worth Ratio (MWR) with Risk-Free Interest Rate - Age 65 (as \%) Using Standardized Mortality Improvement Factor to Cohortize All Countries ${ }^{1}$

A. Male-Nominal

\begin{tabular}{|l|c|c|c|c|c|c|c|c|c|c|c|c|c|}
\hline & \multicolumn{2}{|c|}{ Canada } & \multicolumn{2}{c|}{ US } & \multicolumn{2}{c|}{ Australia } & \multicolumn{2}{c|}{ UK } & \multicolumn{3}{c|}{ Switzerland } & \multicolumn{2}{|c|}{ Singapore $^{2}$} \\
\cline { 2 - 15 } & popul & annuit & popul & annuit & popul & annuit & popul & annuit & popul & annuit & $\begin{array}{l}\text { No } \\
\text { Bonus }\end{array}$ & popul & annuit \\
\hline Level SPIA & 91.4 & 98.1 & 87.9 & 99.5 & 90.7 & 101.3 & 89.8 & 97.7 & 90.9 & 104.6 & 96.4 & & \\
\hline 10YG & 92.8 & 97.4 & & & 91.1 & 99.7 & 93.1 & 98.8 & 93.8 & 104.5 & 96.3 & 103.8 & 106.6 \\
\hline Joint & 93.9 & 98.0 & 88.4 & 97.0 & 92.5 & 98.8 & 92.2 & 98.7 & 89.7 & 98.5 & 90.8 & & \\
\hline Escalating & & & & & & & 89.7 & 99.8 & & & & & \\
\hline
\end{tabular}

B. Male-Price Indexed

\begin{tabular}{|l|c|c|c|c|c|c|l|l|l|}
\hline & \multicolumn{2}{|c|}{ UK } & \multicolumn{2}{c|}{ Chile } & \multicolumn{5}{c|}{ Israel $^{3}$} \\
\cline { 2 - 9 } & popul & annuit & popul & annuit & popul & $\begin{array}{l}\text { Actuaries' } \\
\text { Committee }\end{array}$ & $\begin{array}{l}\text { Managers' } \\
\text { Insurance } \\
\text { Committee }\end{array}$ & $\begin{array}{l}\text { Deferred } \\
\text { Annuity- } \\
\text { Committee } \\
\text { (age 65 } \\
\text { cohort) }\end{array}$ & $\begin{array}{l}\text { Deferred } \\
\text { Annuity- } \\
\text { Committee } \\
\text { (age 25 } \\
\text { cohort) }\end{array}$ \\
\hline Level SPIA & 79.9 & 88.7 & 89.4 & 99.5 & 80.2 & 91.5 & 94.0 & & \\
\hline 10YG & & & 91.0 & 97.7 & 82.4 & 90.5 & 93.0 & & \\
\hline Joint & 80.6 & 88.0 & 93.4 & 101.3 & & & & $(113.6)$ & $(127.1)$ \\
\hline
\end{tabular}

\section{Female-Nominal}

\begin{tabular}{|l|c|c|c|c|c|c|c|c|c|c|c|c|c|c|}
\hline & \multicolumn{2}{|c|}{ Canada } & \multicolumn{2}{c|}{ US } & \multicolumn{2}{c|}{ Australia } & \multicolumn{2}{c|}{ UK } & \multicolumn{3}{c|}{ Switzerland } & \multicolumn{2}{c|}{ Singapore } \\
\cline { 2 - 16 } & Popul & annuit & popul & annuit & popul & annuit & popul & annuit & popul & annuit & $\begin{array}{l}\text { No } \\
\text { Bonus }\end{array}$ & popul & annuit \\
\hline Level SPIA & 95.0 & 97.6 & 89.3 & 97.4 & 92.5 & 100.2 & 92.1 & 97.9 & 96.8 & 103.6 & 95.5 & & \\
\hline 10YG & 95.5 & 97.3 & & & 92.2 & 98.9 & 94.5 & 99.3 & 98.0 & 103.7 & 95.6 & 105.6 & 108.8 \\
\hline Escalating & & & & & & & 92.1 & 100.0 & & & & & \\
\hline
\end{tabular}

\section{Female-Price Indexed}

\begin{tabular}{|l|c|c|c|c|c|c|c|}
\hline \multirow{2}{*}{} & \multicolumn{2}{|c|}{ UK } & \multicolumn{2}{c|}{ Chile } & \multicolumn{3}{c|}{ Israel } \\
\cline { 2 - 7 } & Popul & annuit & popul & annuit & popul & $\begin{array}{l}\text { Actuaries' } \\
\text { Committee }\end{array}$ & $\begin{array}{l}\text { Managers' } \\
\text { Insurance } \\
\text { Committe }\end{array}$ \\
\hline Level SPIA & 80.9 & 87.7 & 89.1 & 97.8 & 76.5 & 90.9 & 93.4 \\
\hline 10YG & & & 90.5 & 96.9 & 78.6 & 90.4 & 92.7 \\
\hline
\end{tabular}

${ }^{1}$ See Tables 3 and 6 for definitions. Table 7 is based on cohort tables constructed imputing Canada's CPP improvement factor for all countries.

${ }^{2}$ For Singapore the MWR is given for an individual who was in the age 55 cohort in 1999 and will begin collecting payouts from the deferred annuity at age 62. See Table 3 and Appendix A for details.

${ }^{3}$ For Israel the MWR in first 3 columns is given for the cohort aged 65 in 1999. For columns on deferred annuity the MWR is given for cohorts age 65 and 25 in 1999, under the hypothesis that these individuals have been and will be in this scheme throughout the ages of 25 and 65 . The MWR is higher for the age 25 cohort because mortality improvement plays a larger role. See Table 3 and Appendix B for further details. 
Table 8: Annuity Margin with Risk-Free Interest Rate (as \%) - Age $6^{1}$

A. Male-Cohort Tables based on own mortality data (Table 6) ${ }^{2}$

\begin{tabular}{|l|l|l|l|l|l|l|l|l|l|l|l|}
\hline & \multicolumn{2}{|c|}{ Canada } & \multicolumn{2}{c|}{ US } & \multicolumn{2}{c|}{ Australia } & \multicolumn{2}{c|}{ UK } & \multicolumn{2}{c|}{ Switzerland } \\
\cline { 2 - 11 } & popul & annuit & popul & annuit & popul & annuit & popul & annuit & popul & annuit \\
\hline Level SPIA & 1.11 & 0.23 & 1.97 & 0.31 & 1.13 & -0.11 & 1.14 & 0.21 & 0.97 & -0.79 \\
\hline 10YG & 0.95 & 0.32 & & & 1.09 & 0.05 & 0.74 & 0.09 & 0.64 & -0.78 \\
\hline Joint & 0.69 & 0.23 & 1.70 & 0.55 & 0.80 & 0.19 & 0.78 & 0.13 & 0.99 & -0.12 \\
& & & & & & & & & $(-1.06)$ & $(-1.75)$ \\
\hline Escalating & & & & & 0.97 & -0.61 & 0.82 & -0.17 & & \\
\hline Indexed level & & & & & & & 2.07 & 1.10 & & \\
\hline
\end{tabular}

B. Male-Cohort Tables based on standardized mortality improvement (Table 7$)^{2}$

\begin{tabular}{|l|c|c|c|c|c|l|l|l|}
\hline & \multicolumn{2}{|c|}{ Singapore } & \multicolumn{2}{|c|}{ Chile } & \multicolumn{5}{c|}{ Israel } \\
\cline { 2 - 9 } & popul & annuit & popul & annuit & popul & $\begin{array}{l}\text { Actuaries } \\
\text { Committee }\end{array}$ & $\begin{array}{l}\text { Managers' } \\
\text { Insurance } \\
\text { Committee }\end{array}$ & $\begin{array}{l}\text { Deferred } \\
\text { Annuity- } \\
\text { Committee }\end{array}$ \\
\hline Level SPIA & & & 1.52 & 0.06 & 2.60 & 0.98 & 0.69 & \\
\hline 10YG & -0.42 & -0.71 & 1.31 & 0.30 & 2.36 & 1.12 & 0.82 & \\
\hline Joint & & & 0.82 & -0.15 & & & & $(-1.33)$ \\
\hline
\end{tabular}

C. Female-Cohort Tables based on own mortality data (Table 6)

\begin{tabular}{|l|c|l|l|l|l|l|l|l|l|l|}
\hline & \multicolumn{2}{|c|}{ Canada } & \multicolumn{2}{c|}{ US } & \multicolumn{2}{c|}{ Australia } & \multicolumn{3}{c|}{ UK } & \multicolumn{2}{c|}{ Switzerland } \\
\cline { 2 - 11 } & popul & annuit & popul & annuit & popul & annuit & popul & annuit & popul & annuit \\
\hline Level SPIA & 0.54 & 0.27 & 1.60 & 0.53 & 0.98 & 0.16 & 0.85 & 0.28 & 0.30 & -0.53 \\
\hline 10YG & 0.49 & 0.30 & & & 1.02 & 0.29 & 0.59 & 0.14 & 0.18 & -0.53 \\
\hline Escalating & & & & & 0.96 & -0.15 & 0.64 & 0.03 & & \\
\hline Indexed & & & & & & & 1.84 & 1.23 & & \\
\hline
\end{tabular}

D. Female-Cohort Tables based on standardized mortality improvement (Table 7) ${ }^{2}$

\begin{tabular}{|l|c|c|c|c|c|l|l|}
\hline & \multicolumn{2}{|c|}{ Singapore } & \multicolumn{2}{c|}{ Chile } & \multicolumn{3}{c|}{ Israel } \\
\cline { 2 - 8 } & popul & annuit & popul & annuit & popul & $\begin{array}{l}\text { Actuaries' } \\
\text { Committee }\end{array}$ & $\begin{array}{l}\text { Managers' } \\
\text { Insurance } \\
\text { Committee }\end{array}$ \\
\hline Level SPIA & & & 1.37 & 0.25 & 2.93 & 0.92 & 0.67 \\
\hline 10 YG & -0.55 & -0.82 & 1.22 & 0.36 & 2.69 & 0.99 & 0.74 \\
\hline
\end{tabular}

${ }^{1}$ For definitions of annuity types and payouts see Table 3, 6, and 7 and Appendices A, B and $\mathrm{C}$. Margin means fixed \% by which annual interest rate received by average population member or average annuitant is less (or greater) than risk free rate. A positive margin indicates MWR < $100 \%$ and vice versa.

${ }^{2}$ Where a country's own projections are available we use their cohort table (Panels A and C), while if the country does not have its own cohort table (Singapore, Chile, and Israel), we use a cohortized version by imputing Canada's improvement factor (Panels B and D). 
Table 9: Money's Worth Ratio (MWR) with Risky Interest Rate (as \%) - Age $65^{\text {a }}$

A. Male: Cohort Tables

\begin{tabular}{|l|c|c|c|c|c|c|c|c|c|c|c|}
\hline & \multicolumn{2}{|c|}{ Canada } & \multicolumn{2}{c|}{ US } & \multicolumn{2}{c|}{ Australia } & \multicolumn{3}{c|}{ UK } & \multicolumn{3}{c|}{ Switzerland } \\
\cline { 2 - 13 } & popul & annuit & popul & annuit & popul & annuit & popul & annuit & popul & annuit & $\begin{array}{c}\text { No } \\
\text { Bonus }\end{array}$ \\
\hline Level SPIA & 82.4 & 87.9 & 77.7 & 87.3 & 81.9 & 89.6 & 82.1 & 87.9 & 81.4 & 94.4 & 87.0 \\
\hline 10YG & 83.7 & 87.4 & & & 82.4 & 88.4 & 85.1 & 88.9 & 84.1 & 94.3 & 86.9 \\
\hline Joint & 83.3 & 86.8 & 77.4 & 84.3 & 80.4 & 84.6 & 82.9 & 87.3 & 78.9 & 87.5 & 80.7 \\
& & & & & & & & & $(96.8)$ & $(103.5)$ & $(95.4)$ \\
\hline Escalating & & & & & 77.7 & 90.5 & 81.2 & 88.3 & & & \\
\hline Indexed level & & & & & & & 72.2 & 78.4 & & & \\
\hline
\end{tabular}

B. Male: Standard Cohortized Tables

\begin{tabular}{|l|c|c|c|c|c|c|c|c|c|}
\hline & \multicolumn{2}{|c|}{ Singapore } & \multicolumn{2}{|c|}{ Chile } & \multicolumn{5}{|c|}{ Israel } \\
\cline { 2 - 9 } & popul & annuit & popul & annuit & popul & $\begin{array}{c}\text { Actuaries' } \\
\text { Committee }\end{array}$ & $\begin{array}{c}\text { Managers' } \\
\text { Insurance } \\
\text { Committee }\end{array}$ & $\begin{array}{c}\text { Deferred } \\
\text { Annuity- } \\
\text { Committee } \\
\text { (age 65 } \\
\text { cohort) }\end{array}$ & $\begin{array}{c}\text { Deferred } \\
\text { Annuity- } \\
\text { Committee } \\
\text { (age 25 } \\
\text { cohort) }\end{array}$ \\
\hline Level SPIA & & & 81.3 & 89.7 & 72.2 & 81.3 & 83.6 & & \\
\hline 10YG & 92.7 & 94.8 & 82.8 & 88.1 & 74.2 & 80.6 & 82.8 & & \\
\hline Joint & & & 83.8 & 90.1 & & & & $(99.3)$ & $(109.1)$ \\
\hline
\end{tabular}

C. Female: Cohort Tables

\begin{tabular}{|l|c|c|c|c|c|c|c|c|c|c|c|}
\hline & \multicolumn{2}{|c|}{ Canada } & \multicolumn{2}{c|}{ US } & \multicolumn{2}{c|}{ Australia } & \multicolumn{3}{c|}{ UK } & \multicolumn{3}{c|}{ Switzerland } \\
\cline { 2 - 13 } & popul & annuit & popul & annuit & popul & annuit & popul & annuit & popul & annuit & No Bonus \\
\hline Level SPIA & 84.0 & 86.4 & 78.1 & 84.7 & 81.3 & 86.5 & 82.3 & 86.0 & 84.5 & 91.6 & 84.5 \\
\hline 10YG & 84.5 & 86.2 & & & 81.1 & 85.5 & 84.4 & 87.3 & 85.7 & 91.6 & 84.5 \\
\hline Escalating & & & & & 75.6 & 84.8 & 80.4 & 85.2 & & & \\
\hline Indexed level & & & & & & & 70.6 & 74.7 & & & \\
\hline
\end{tabular}

D. Female: Standard Cohortized Tables

\begin{tabular}{|l|c|c|c|c|c|c|c|}
\hline & \multicolumn{2}{|c|}{ Singapore } & \multicolumn{2}{c|}{ Chile } & \multicolumn{3}{c|}{ Israel } \\
\cline { 2 - 8 } & popul & annuit & popul & annuit & popul & $\begin{array}{c}\text { Actuaries' } \\
\text { Committee }\end{array}$ & $\begin{array}{c}\text { Managers' } \\
\text { Insurance } \\
\text { Committee }\end{array}$ \\
\hline Level SPIA & & & 80.1 & 87.1 & 68.4 & 79.6 & 81.7 \\
\hline 10YG & 92.7 & 94.9 & 81.4 & 86.3 & 68.4 & 79.2 & 81.3 \\
\hline
\end{tabular}

Notes:

${ }^{\mathrm{a}}$ Risky rate $=$ government term structure $+1.4 \%$

For definitions of annuity types, payouts and mortality tables, see Table 3, 6, and 7 and Appendices A, B and C. 
Table 10. Selection: Difference in MWR's Between Annuitants and Population ${ }^{1}$

\section{A. Male}

\begin{tabular}{|l|c|c|c|c|}
\hline Countries & $\begin{array}{c}\text { Annuitant - } \\
\text { population: Level } \\
\text { SPIA, Risk-Free }\end{array}$ & $\begin{array}{c}\text { Annuitant - } \\
\text { population: Level } \\
\text { SPIA, Risky }\end{array}$ & $\begin{array}{c}\text { Annuitant- } \\
\text { population: Joint } \\
\text { Annuity, Risk-Free }\end{array}$ & $\begin{array}{c}\text { Annuitant- } \\
\text { population: Joint } \\
\text { Annuity, Risky }^{2}\end{array}$ \\
\hline Canada & 6.7 & 5.5 & 4.1 & 3.5 \\
\hline US & 11.6 & 9.6 & 8.6 & 6.9 \\
\hline Australia & 9.9 & 7.7 & 6.9 & 4.2 \\
\hline UK & 7.1 & 5.8 & 5.5 & 4.4 \\
\hline Switzerland & 13.7 & 13.0 & 8.8 & 8.6 \\
& & & $(5.8)$ & $(6.7)$ \\
\hline Singapore & NA & NA & 2.8 & 2.1 \\
\hline Chile & 10.1 & 8.4 & 7.9 & 6.3 \\
\hline Israel & 11.3 & 9.1 & 8.1 & 6.4 \\
\hline
\end{tabular}

\section{B. Female}

\begin{tabular}{|l|c|c|}
\hline Countries & $\begin{array}{c}\text { Annuitant - } \\
\text { population: Level } \\
\text { SPIA, Risk-Free }\end{array}$ & $\begin{array}{c}\text { Annuitant - } \\
\text { population: Level } \\
\text { SPIA, Risky }\end{array}$ \\
\hline Canada & 2.6 & 2.4 \\
\hline US & 8.1 & 6.6 \\
\hline Australia & 7.7 & 5.2 \\
\hline UK & 5.8 & 3.7 \\
\hline Switzerland & 6.8 & 7.1 \\
\hline Singapore & NA & NA \\
\hline Chile & 8.7 & 7.0 \\
\hline Israel & 14.4 & 11.2 \\
\hline
\end{tabular}

${ }^{1}$ Risk-free numbers for Canada, US, UK and Australia are from Table 6, others are from Table 7, to standardize mortality improvement factor for population and annuitants. Risky numbers are based on Table 9 .

${ }^{2}$ Terms of joint annuity vary as described in Table 3. For Singapore $15 \mathrm{YG}$ is given instead of joint. For Israel voluntary market payouts for $10 \mathrm{YG}$ are used. 


\section{Table 11}

Differences in MWR (in \%) and EPDV of Lifetime Payouts (per 100 premium): Attribution to Interest versus Mortality Rate Differences, Using Canada as Standard

A. Male

\begin{tabular}{|c|c|c|c|c|c|}
\hline & $\begin{array}{c}\text { All Canada } \\
\text { data } \\
\text { (Canada's } \\
\text { EPDV) } \\
\\
\text { (1) }\end{array}$ & $\begin{array}{c}\text { Monthly } \\
\text { payout from } \\
\text { own-country; } \\
\text { other } \\
\text { variables } \\
\text { standardized } \\
(2) \\
\end{array}$ & $\begin{array}{c}\text { Monthly } \\
\text { payout }+ \\
\text { interest rates- } \\
\text { own-country; } \\
\text { mortality } \\
\text { rates } \\
\text { standardized } \\
(3) \\
\end{array}$ & $\begin{array}{c}\text { Payout }+ \\
\text { interest rates+ } \\
\text { period table - } \\
\text { own-country; } \\
\text { improvement } \\
\text { factor } \\
\text { standard } \\
(4) \\
\end{array}$ & $\begin{array}{l}\text { All data from } \\
\text { own-country }\end{array}$ \\
\hline US & 98.1 & 97.2 & 96.8 & 99.5 & 97.4 \\
\hline Australia & 98.1 & 92.8 & 98.3 & 101.3 & 101.0 \\
\hline UK & 98.1 & 96.4 & 105.9 & 97.7 & 98.3 \\
\hline Switzerland (PIII) & 98.1 & 78.2 & 98.5 & 104.6 & 108.2 \\
\hline Singapore & 97.4 & 99.4 & 108.5 & 106.6 & 102.4 \\
\hline Chile & 98.1 & 108.7 & 102.2 & 99.5 & 96.7 \\
\hline Israel & 98.1 & 82.9 & 96.2 & 91.5 & 88.2 \\
\hline Average & 98.0 & 93.7 & 100.9 & 100.5 & 98.9 \\
\hline Standard deviation & 0.3 & 10.3 & 4.8 & 5.2 & 6.1 \\
\hline Range & 0.7 & 30.5 & 12.3 & 15.1 & 20.0 \\
\hline
\end{tabular}

B. Female

\begin{tabular}{|l|r|r|r|r|r|}
\hline US & 97.6 & 97.6 & 92.1 & 97.4 & 95.4 \\
\hline Australia & 97.6 & 91.5 & 97.6 & 100.2 & 98.4 \\
\hline UK & 97.6 & 94.3 & 105.2 & 97.9 & 97.4 \\
\hline Switzerland (PIII) & 97.6 & 77.5 & 99.2 & 103.6 & 105.7 \\
\hline Singapore & 97.3 & 98.7 & 108.8 & 108.8 & 103.9 \\
\hline Chile & 97.6 & 106.6 & 99.7 & 97.8 & 94.9 \\
\hline Israel & 97.6 & 81.4 & 96.5 & 90.9 & 86.9 \\
\hline Average & 97.6 & 92.5 & 99.9 & 99.8 & 97.5 \\
\hline Standard deviation & 0.1 & 10.1 & 5.6 & 6.1 & 6.2 \\
\hline Range & 0.3 & 29.1 & 16.7 & 17.9 & 28.8 \\
\hline
\end{tabular}

Note: For definitions see Tables 3, 6 and 7.

Column 4 is from Table 7 and column 5 is from Table 6. Comparison is for level SPIA for all countries except Singapore, where it is for 15YG. Numbers for Singapore, Chile and Israel are italicized in column 5 because they do not have their own improvement factor or cohort tables; they use period tables. 


\section{Table 11}

Rank Order by Interest Rate, Monthly and Expected Lifetime Payouts, Level SPIA

\begin{tabular}{|l|l|l|l|l|l|}
\hline Country & $\begin{array}{l}8 \text {-Year } \\
\text { interest } \\
\text { rate }\end{array}$ & $\begin{array}{l}\text { Monthly } \\
\text { Payout }\end{array}$ & $\begin{array}{l}\text { Expected lifetime } \\
\text { payout--standard } \\
\text { mortality }\end{array}$ & $\begin{array}{l}\text { Expected lifetime } \\
\text { payout--own } \\
\text { mortality }\end{array}$ & $\begin{array}{l}\text { Own-country } \\
\text { improvement } \\
\text { factor }\end{array}$ \\
\hline Chile & 1 & 1 & 3 & 7 & 7 \\
\hline Canada & 2 & 2 & 6 & 5 & 4 \\
\hline US & 3 & 3 & 7 & 6 & 5 \\
\hline Australia & 4 & 5 & 5 & 3 & 2 \\
\hline UK & 5 & 4 & 2 & 4 & 3 \\
\hline Singapore & 6 & 6 & 1 & 2 & 6 \\
\hline Israel & 7 & 7 & 8 & 8 & 8 \\
\hline Switzerland & 8 & 8 & 4 & 1 & 1 \\
\hline
\end{tabular}

Note: Column 2 is from Table 3. Column 3 is from column 3, Table 11. Column 4 is from Table 6 and column 5, Table 9. Columns 1 and 5 are from Appendices E and F. 
Table 12: Insurance Company Investment Portfolio

\begin{tabular}{|c|c|c|c|c|c|c|c|c|c|}
\hline \multirow{2}{*}{\multicolumn{2}{|c|}{ Country }} & \multicolumn{2}{|l|}{ Bonds } & \multirow{2}{*}{$\begin{array}{l}\text { Loans \& } \\
\text { Mortgages }\end{array}$} & \multirow[t]{2}{*}{ Equities } & \multirow{2}{*}{$\begin{array}{l}\text { Real } \\
\text { Estate } \\
\text { and } \\
\text { Land } \\
\end{array}$} & \multirow{2}{*}{$\begin{array}{l}\text { Liquid } \\
\text { Assets }\end{array}$} & \multirow[t]{2}{*}{ Other } & \multirow[t]{2}{*}{ Total } \\
\hline & & \multirow[t]{2}{*}{$\begin{array}{l}\text { Public } \\
\text { Bonds }\end{array}$} & \multirow[t]{2}{*}{$\begin{array}{l}\text { Corporate } \\
\text { Bonds }\end{array}$} & & & & & & \\
\hline \multicolumn{2}{|l|}{ US } & & & & & & & & \\
\hline \multicolumn{2}{|l|}{1970} & 3.9 & 36.9 & 45.0 & 7.7 & & 1.9 & 4.6 & 100.0 \\
\hline \multicolumn{2}{|l|}{1990} & 14.2 & 42.0 & 24.4 & 8.3 & & 5.1 & 6.0 & 100.0 \\
\hline \multicolumn{2}{|l|}{1995} & 17.6 & 42.3 & 15.0 & 16.7 & & 3.6 & 5.1 & 100.0 \\
\hline \multicolumn{2}{|l|}{1998} & 11.1 & 40.8 & 11.5 & 27.3 & & 6.8 & 2.5 & 100.0 \\
\hline \multicolumn{2}{|l|}{1999} & 10.0 & 38.2 & 10.7 & 32.9 & & 7.0 & 1.1 & 100.0 \\
\hline Separate account & 1999 & 4.7 & 8.5 & 0.6 & 81.1 & 1.2 & 0.1 & 3.8 & 100.0 \\
\hline General account & 1999 & 15.7 & 55.5 & 16.3 & 5.1 & 1.3 & 0.2 & 5.9 & 100.0 \\
\hline \multicolumn{2}{|l|}{ Canada } & \multirow{2}{*}{\multicolumn{2}{|c|}{37.0}} & & & & & & \\
\hline \multicolumn{2}{|l|}{1970} & & & 48.2 & 6.9 & 4.6 & 1.0 & 2.2 & 100.0 \\
\hline \multicolumn{2}{|l|}{1990} & \multicolumn{2}{|l|}{39.2} & 38.0 & 10.8 & 5.1 & 1.7 & 5.1 & 100.0 \\
\hline \multicolumn{2}{|l|}{1995} & \multicolumn{2}{|l|}{45.0} & 28.3 & 13.1 & 5.0 & 4.4 & 4.2 & 100.0 \\
\hline \multicolumn{2}{|l|}{$\begin{array}{l}1998 \\
1090\end{array}$} & \multicolumn{2}{|l|}{44.0} & 20.9 & 22.4 & 3.3 & 4.9 & 4.6 & 100.0 \\
\hline 1999 & & 40.0 & & 17.5 & 29.3 & 2.9 & 5.8 & 4.5 & 100.0 \\
\hline Segregated & 1999 & 16.3 & & 2.0 & 70.4 & 1.8 & 8.7 & 0.9 & 100.0 \\
\hline Non-segregated & 1999 & 49.8 & & 21.9 & 12.3 & 3.4 & 4.6 & 8.0 & 100.0 \\
\hline UK & & & & & & & & & \\
\hline 1998 & & 30.2 & & 0.8 & 53.4 & 8.1 & & 7.5 & 100.0 \\
\hline Switzerland & & & & & & & & & \\
\hline 1970 & & 21.5 & & 50.4 & & 20.2 & 5.5 & 2.4 & 100.0 \\
\hline 1990 & & 35.5 & & 35.3 & 5.8 & 14.7 & 6.8 & 2.0 & 100.0 \\
\hline 1995 & & 38.7 & & 26.4 & 13.3 & 12.1 & 7.7 & 1.8 & 100.0 \\
\hline 1998 & & 39.5 & & 19.3 & 18.3 & 9.6 & 4.4 & 9.0 & 100.0 \\
\hline Australia & & & & & & & & & \\
\hline Total & 1995 & 25.0 & & 6.5 & 29.9 & 7.6 & 6.8 & 24.0 & 99.8 \\
\hline & 1998 & 35.2 & & 5.6 & 31.9 & 6.2 & 3.6 & 17.5 & 100.0 \\
\hline & 1999 & 34.8 & & 6.1 & 33.0 & 6.0 & 3.2 & 16.9 & 100.0 \\
\hline Unit linked & 1999 & 33.0 & & 1.4 & 38.2 & 4.6 & 3.1 & 19.8 & 100.1 \\
\hline Non-Unit linked & 1999 & 37.6 & & 13.1 & 25.4 & 8.0 & 3.4 & 12.5 & 100.0 \\
\hline Chile & & & & & & & & & \\
\hline 1990 & & 40.0 & 21.0 & 15.0 & 5.0 & & 6.0 & 13.0 & 100.0 \\
\hline 1995 & & 37.0 & 14.0 & 15.0 & 10.0 & & 8.0 & 16.0 & 100.0 \\
\hline 1998 & & 39.0 & 7.0 & 33.0 & 4.0 & & 6.0 & 11.0 & 100.0 \\
\hline Singapore & & & & & & & & & \\
\hline 1996 & & 5.5 & 17.7 & 15.5 & 32.0 & 7.2 & 19.4 & 2.7 & 100.0 \\
\hline 1999 & & 9.7 & 24.4 & NA & 27.2 & NA & 16.1 & 22.6 & 100.0 \\
\hline
\end{tabular}




\section{Sources:}

US--www.federalreserve.gov Level of Funds Accounts Financial Assets and Liabilities, Information on general and separate account is taken from ACLI Life Insurers Fact Book 2000, Table 8.4. (Government and corporate bonds include foreign bonds, 'other' includes 'other invested assets' and 'non-invested assets.').

Canada-Canadian Life and Health Insurance Facts (2000 Edition). Office of the Superintendent of Financial Institutions, CLHIA. www.clhia.ca/E3.htm\#OTHERat.

UK-Ned Cazalet's analysis of the DTI returns from Murthi, Orszag and Orszag 1999

Switzerland--Private Insurance Institutions in Switzerland 1995 (Swiss Table 2.3.2), Federal Office for the Private Insurance Industry, Bern.

Australia--www.apra.gov.au, Australia Prudential Regulation Authority, data from June. "Other" includes overseas assets.

Chile-Insurance Superintendency Bulletin, as quoted in Callund 1999.

Singapore - Chang 1999 and communications with Chang for 1996 and 1997 data; 1999 data source: http://www.mas.gov.sg/singfinsec/ (Monetary Authority of Singapore)

Notes:

1. Canada, UK, Switzerland, and Australia do not separate government bonds and corporate bonds.

2. Most investments in Israel are in government bonds but breakdowns of portfolios are not available. 
Table 13. Imputed Insurance Company Investment Portfolio Spread

\section{A. Based on Country Returns}

\begin{tabular}{|c|c|c|c|c|c|c|c|c|}
\hline \multirow{2}{*}{\multicolumn{2}{|c|}{ Country }} & \multicolumn{2}{|l|}{ Bonds } & \multirow{2}{*}{$\begin{array}{l}\text { Loans } \\
\& \\
\text { Mortg } \\
\text { ages }\end{array}$} & \multirow[t]{2}{*}{ Equities } & \multirow{2}{*}{$\begin{array}{l}\text { Real } \\
\text { Estate } \\
\text { and } \\
\text { Land }\end{array}$} & \multirow{2}{*}{$\begin{array}{l}\text { Liquid } \\
\text { Assets }\end{array}$} & \multirow[t]{2}{*}{ Total } \\
\hline & & $\begin{array}{l}\text { Public } \\
\text { Bonds }\end{array}$ & $\begin{array}{l}\text { Corporate } \\
\text { Bonds }\end{array}$ & & & & & \\
\hline \multicolumn{2}{|l|}{ US } & & & & & & & \\
\hline \multicolumn{2}{|l|}{1990} & & 0.223 & 0.864 & 0.443 & & 0.043 & 1.573 \\
\hline \multicolumn{2}{|l|}{1995} & & 0.222 & 0.508 & 0.876 & & 0.030 & 1.636 \\
\hline \multicolumn{2}{|l|}{1998} & & 0.209 & 0.377 & 1.401 & & 0.056 & 2.043 \\
\hline \multicolumn{2}{|l|}{1999} & & 0.193 & 0.351 & 1.661 & & 0.057 & 2.262 \\
\hline Separate account & 1999 & & 0.044 & 0.020 & 4.215 & 0.054 & 0.001 & 4.334 \\
\hline General account & 1999 & & 0.295 & 0.559 & 0.270 & 0.060 & 0.002 & 1.186 \\
\hline \multicolumn{2}{|l|}{ Canada } & & & & & & & \\
\hline \multicolumn{2}{|l|}{1990} & 0.268 & & 1.143 & 0.342 & 0.400 & 0.013 & 2.166 \\
\hline \multicolumn{2}{|l|}{1995} & 0.306 & & 0.842 & 0.410 & 0.385 & 0.032 & 1.975 \\
\hline \multicolumn{2}{|l|}{1998} & 0.300 & & 0.624 & 0.703 & 0.257 & 0.036 & 1.920 \\
\hline \multicolumn{2}{|l|}{1999} & 0.272 & & 0.523 & 0.921 & 0.227 & 0.042 & 1.985 \\
\hline Segregated & 1999 & 0.107 & & 0.057 & 2.129 & 0.134 & 0.061 & 2.489 \\
\hline Non-segregated & 1999 & 0.352 & & 0.678 & 0.401 & 0.273 & 0.035 & 1.740 \\
\hline \multicolumn{9}{|l|}{ UK } \\
\hline \multicolumn{2}{|l|}{1998} & 0.180 & & 0.006 & 4.212 & 0.044 & & 4.442 \\
\hline \multicolumn{2}{|l|}{ Switzerland } & & & & & & & \\
\hline \multicolumn{2}{|l|}{1990} & 0.085 & & 0.889 & 0.540 & 0.003 & 0.106 & 1.623 \\
\hline \multicolumn{2}{|l|}{1995} & 0.090 & & 0.658 & 1.200 & 0.002 & 0.116 & 2.066 \\
\hline \multicolumn{2}{|l|}{1998} & 0.087 & & 0.476 & 1.564 & 0.180 & 0.062 & 2.370 \\
\hline \multicolumn{9}{|l|}{ Australia } \\
\hline \multirow[t]{3}{*}{ Total } & 1995 & 0.329 & & 0.360 & 3.320 & 0.451 & 0.170 & 4.630 \\
\hline & 1998 & 0.427 & & 0.285 & 3.248 & 0.338 & 0.083 & 4.381 \\
\hline & 1999 & 0.419 & & 0.308 & 3.336 & 0.325 & 0.073 & 4.461 \\
\hline Unit linked & 1999 & 0.411 & & 0.073 & 3.996 & 0.258 & 0.073 & 4.811 \\
\hline Non-Unit linked & 1999 & 0.430 & & 0.629 & 2.438 & 0.411 & 0.074 & 3.982 \\
\hline
\end{tabular}

Note: Spread for each asset class = proportion of total portfolio in that class (from Table 11) multiplied by the long run return to that class from Davis 2001 (returns from each country, see fn 23). For countries that do not distinguish public bonds and corporate bond, we treat the bonds as half public and half corporate. US and Swiss spreads on mortgage and loans are calculated separately, and the sum is given in the loans \& mortgages column. 


\section{B. Based on Average Returns}

\begin{tabular}{|c|c|c|c|c|c|c|c|c|}
\hline \multirow{2}{*}{\multicolumn{2}{|c|}{ Country }} & \multicolumn{2}{|l|}{ Bonds } & \multirow{2}{*}{$\begin{array}{l}\text { Loans } \\
\& \\
\text { Mortg } \\
\text { ages }\end{array}$} & \multirow[t]{2}{*}{ Equities } & \multirow{2}{*}{$\begin{array}{l}\text { Real } \\
\text { Estate } \\
\text { and } \\
\text { Land }\end{array}$} & \multirow{2}{*}{$\begin{array}{l}\text { Liquid } \\
\text { Assets }\end{array}$} & \multirow[t]{2}{*}{ Total } \\
\hline & & $\begin{array}{l}\text { Public } \\
\text { Bonds }\end{array}$ & $\begin{array}{l}\text { Corporate } \\
\text { Bonds }\end{array}$ & & & & & \\
\hline \multicolumn{2}{|l|}{ US } & & & & & & & \\
\hline \multicolumn{2}{|l|}{1990} & & 0.446 & 0.623 & 0.558 & & 0.005 & 1.633 \\
\hline \multicolumn{2}{|l|}{1995} & & 0.444 & 0.379 & 1.104 & & 0.004 & 1.930 \\
\hline \multicolumn{2}{|l|}{1998} & & 0.419 & 0.282 & 1.765 & & 0.007 & 2.473 \\
\hline \multicolumn{2}{|l|}{1999} & & 0.387 & 0.261 & 2.093 & & 0.007 & 2.748 \\
\hline Separate account & 1999 & & 0.088 & 0.015 & 5.311 & 0.059 & 0.000 & 5.473 \\
\hline General account & 1999 & & 0.590 & 0.416 & 0.340 & 0.065 & 0.000 & 1.411 \\
\hline \multicolumn{2}{|l|}{ Canada } & & & & & & & \\
\hline \multicolumn{2}{|l|}{1990} & \multicolumn{2}{|l|}{0.206} & 0.962 & 0.719 & 0.260 & 0.002 & 2.149 \\
\hline \multicolumn{2}{|l|}{1995} & \multicolumn{2}{|l|}{0.235} & 0.709 & 0.862 & 0.250 & 0.005 & 2.060 \\
\hline \multicolumn{2}{|l|}{1998} & \multicolumn{2}{|l|}{0.231} & 0.525 & 1.477 & 0.167 & 0.005 & 2.405 \\
\hline \multicolumn{2}{|l|}{1999} & \multicolumn{2}{|l|}{0.209} & 0.440 & 1.934 & 0.147 & 0.006 & 2.737 \\
\hline Segregated & 1999 & \multicolumn{2}{|l|}{0.082} & 0.048 & 4.471 & 0.087 & 0.009 & 4.697 \\
\hline \multirow{2}{*}{\multicolumn{2}{|c|}{$\begin{array}{l}\text { Non-segregated } \\
\text { UK }\end{array}$}} & \multicolumn{2}{|l|}{0.271} & 0.571 & 0.842 & 0.177 & 0.005 & 1.867 \\
\hline & & \multirow{2}{*}{\multicolumn{2}{|c|}{0.163}} & & & & & \\
\hline \multicolumn{2}{|l|}{1998} & & & 0.021 & 3.635 & 0.420 & & 4.239 \\
\hline \multicolumn{2}{|l|}{ Switzerland } & \multirow{2}{*}{\multicolumn{2}{|c|}{0.212}} & & & & & \\
\hline \multicolumn{2}{|l|}{1990} & & & 1.015 & 0.436 & 0.008 & 0.008 & 1.680 \\
\hline \multicolumn{2}{|l|}{1995} & \multicolumn{2}{|l|}{0.225} & 0.735 & 0.969 & 0.007 & 0.009 & 1.945 \\
\hline 1998 & & 0.217 & & 0.509 & 1.263 & 0.509 & 0.005 & 2.503 \\
\hline Australia & & & & & & & & \\
\hline Total & 1995 & 0.165 & & 0.206 & 2.490 & 0.481 & 0.009 & 3.350 \\
\hline & 1998 & 0.213 & & 0.163 & 2.436 & 0.361 & 0.004 & 3.177 \\
\hline & 1999 & 0.209 & & 0.176 & 2.502 & 0.347 & 0.004 & 3.238 \\
\hline Unit linked & 1999 & 0.205 & & 0.042 & 2.997 & 0.275 & 0.004 & 3.523 \\
\hline Non-Unit linked & 1999 & 0.215 & & 0.359 & 1.829 & 0.439 & 0.004 & 2.846 \\
\hline
\end{tabular}

Note: Spread for each asset class $=$ proportion of total portfolio in that class (from Table 11) multiplied by the long run return to that class from Davis 2001 (average returns from 12 OECD countries, see fn 23). For countries that do not distinguish public bonds and corporate bond, we treat the bonds as half public and half corporate. US and Swiss spreads on mortgage and loans are calculated separately, and the sum is given in the loans \& mortgages column. 


\section{Appendix A Singapore}

Annuities in Singapore are sold pursuant to the Minimum Sum Scheme, which requires all workers to set aside a minimum sum out of his or her mandatory Central Provident Fund (CPF) account at age 55. The Minimum Sum was $\$ 55,000$ in mid-1999 when we collected our data, but will rise to $\$ 80,000$ by 2003 . This money can go into a special CPF or bank account from which gradual withdrawals will begin at age 62, or into a deferred annuity that begins payouts at age 62. If the person dies before age $62 \mathrm{his} / \mathrm{her}$ capital is returned with interest. After age 62 payments are usually guaranteed for a period of 15 years $(15 \mathrm{YG})$, to meet the "return of capital" requirement imposed by the CPF. Effectively, this means that the money is put into a term deposit for 7 years and proceeds are used to purchase a deferred annuity with 15 YG.

To calculate the MWR on this product, we first need to obtain the monthly payout. We start with the $\$ 55,000$ that was required to be set aside under the Minimum Sum Scheme by a 55-year old in mid-1999. According to lists supplied by the CPF, the average payout for a deferred annuity for a male with $15 \mathrm{YG}$ was $\$ 484$ monthly. The premium paid for this annuity is $\$ 55,000$ at age 55 or $\$ 74,397$ at age 62 , when compounded using the 7 -year bond rate. (The rationale for using the 7-year bond rate is that the money is not available for withdrawal or consumption during this time period, and therefore it could be invested to earn the 7-year return. Below, we also present the rationale for and results of using a lower compounding rate). But Table 1 gives payouts for a $\$ 100,000$ premium; therefore we wish to find the hypothetical payout for an accumulation of $\$ 100,000$ by age 62 . Assuming a constant payout per dollar of premium regardless of premium size, we multiply $\$ 484$ by $100,000 / 74,397$, obtaining $\$ 650$ as the monthly payout for a premium of $\$ 100,000$ at age 62 (Table 1). $\$ 100,000$ at age 62 is equivalent to $\$ 73,927$ at age 55. While this amount was outside the bounds of the Minimum Sum Scheme in 1999, it will no longer be outside by July 2002, by which time $\$ 75,000$ will have to be set aside at age 55 .

We then calculate the MWR on this amount, using the term structure beginning at year 7 for discounting back to age 62 and the 7-year bond rate for discounting back from age 62 to age 55. A similar calculation was followed for female payouts and MWR.

We made two other calculations of payouts in Singapore. First, we assumed the individual had invested $\$ 100,000$ at age 55. This would have grown to $\$ 135,268$ by age 62 and the payout would have been $\$ 880$ monthly. This shows that the same premium paid 7 years in advance will produce a much larger monthly payout - which is hardly surprising. The entire gain in this case comes from the compounding effect, not from the pooling of mortality experience, since the principle plus interest is returned to the annuitant's estate if he should die before age 62. (If mortality were also pooled, this would produce an even higher payout from the deferred annuity). However, both the $\$ 650$ for $\$ 100,000$ at age 62 and the $\$ 880$ for $\$ 100,000$ at age 55 will yield the same MWR, so long as both compounding and discounting are done at the same 7-year bond rate between ages 55 and 62 .

Second, one could argue that the 7-year bond rate is not the correct rate for compounding and discounting, since the worker did not have the option of consuming his/her Minimum 
Sum or investing it in the broader market at age 55. Instead, the only options were annuitization or keeping the money in the CPF or bank. While the CPF and bank rates vary from year to year, averaged over long periods they have been less than $3 \%$ annually. Thus, $3 \%$ is the opportunity cost to annuitants in this constrained situation. Using 3\% as the rate for compounding and discounting between ages 55 and 62, to obtain $\$ 100,000$ by age 62 would have required an investment of $\$ 81,309$ at age 55, and this would have yielded a monthly payout of $\$ 716$. The MWR on this payout would have been $10 \%$ higher than the MWR on the $\$ 650$. This shows that, when the annuity option is compared with the other constrained options available in the Minimum Sum Scheme, it is more favorable than when compared with the unconstrained options available in the broader market. However, in this paper we use the broader market as our frame of reference.

Another set of issues in Singapore concerns mortality tables. Good life tables for population or for annuitants are not available in Singapore. For mortality rates in Table 6 we use A90 for the population and A90 with 2-year setback for annuitants since that is what most insurance companies use. The A90 tables are based on UK data for 1967-70, projected upward to 1990 for UK. In Table 6 we take these as the period tables for Singapore in $1998 / 99$, since this is the practice of the insurance industry and its regulators. While good life tables by age for the Singapore population are not publicly available, expected deaths according to the crude table that is available for 1998/99 are close to expected deaths implied by A90. However, the A90 with 2-year setback appears to overstate mortality rates for annuitants, according to data from the largest life insurance company in Singapore (Chang, p. 10). Therefore the annuitant period MWR in Tables 6 and 7 are probably understated.

For Table 7 we start with these estimated period tables for 1998/99, and cohortize them for the cohort that was age 55 in 1999 (so will be 62 in 2006), using the standard Canadian improvement factor. Both in Tables 6 and 7, but especially in the latter, the MWR exceeds $100 \%$.

While our calculations deal with fixed annuities, most of the annuity business in Singapore takes the form of "participating" annuities where the guaranteed payout is smaller, with some upside potential that is determined on a discretionary basis. If people live longer than the companies expect, this upside potential may not be realized and in effect the "participating" consumers may end up cross-subsidizing the guaranteed consumers (see footnote on the UK Equitable case). As the purchase of annuities grows, it will become increasingly important to base the prices and payouts on accurate mortality tables and projections. 


\section{Appendix B: Calculation of Payouts and MWR for Quasi-Mandatory Deferred Annuity in Israel}

In Israel under the new deferred annuity system, the worker buys a bit of an annuity each year, and when he retires these bits are all added up to form his pension. The pension rights for each year are age-specific. For example, a 25-year old male pays a $17.5 \%$ contribution and then, upon reaching age 65 , gets a joint annuity for his contribution that year that equals $6.48 \%$ of his (age-25) wage, with 60\% to surviving spouse upon his death. But for that same contribution rate the 35 year old worker gets only $4.03 \%$ of his (age-35) wage, because his (age-35) contribution has fewer years to accumulate with interest. If we add up all the pension rights accumulated between ages 25 and 65, we find the worker at age 65 is entitled to a pension that equals $120.97 \%$ of his wage, assuming 0 real wage growth. All pension rights are price-indexed, as are all long-term financial transactions in Israel.

To calculate how much the worker pays over his lifetime for his annuity, and how much he collects after retirement, we started with a table from Spivak (2000) that gives pension rights as a $\%$ of wage for the contribution that a worker makes at each age. This table tells us that (as stated above), if we assume 0 real wage growth, the pension rights that a worker has acquired if he starts contributing at age 25 and continues contributing every year until age 65 add up to $120.97 \%$ of his wage. Prior to age 65 this accumulation provides survivors and disability insurance, in addition to building his retirement fund. Based on the experience of other countries, we attribute $1.5 \%$ of the $17.5 \%$ contribution to the pooled amount that is necessary to top-up the individual's accumulation to cover the cost of the promised S\&D benefits. This leaves a $16 \%$ net contribution rate that we may conceive of as being allocated to the individual's old age pension. We assume that this accumulation earns a net return of $4 \%$ annually, which is the same as the discount rate during the annuity stage. (The difference between this net rate and the higher gross subsidized rate is assumed to cover administrative costs).

For comparability with other countries in Tables 6 and 7, we want to find the monetary payout from a $\$ 100,000$ accumulation at age 65 . To accomplish this, we find the constant wage for which $16 \%$ each year, compounded at the assumed real interest rate of $4 \%$, equals $\$ 100,000$ after 40 years. This constant real wage turns out to be $\$ 6577$. We then multiply $\$ 6577$ by $120.97 \%$ to get the annual deferred pension, and divide by 12 to get the monthly payout of $\$ 663$ (Table 3). Using this number, combined with the $\$ 100,000$ premium at age 65 , we obtain the MWR for a joint annuity with $60 \%$ to survivor of $109.2 \%$ in Table 6 , $113.6 \%$ in Table 7 where the age 65 cohort is cohortized. (Note that the $\$ 100,000$ premium at age 65 is equivalent in present value to a lump sum of $\$ 20,829$ paid at age 25 or $\$ 1052$ paid annually between ages 25-65).

This is the MWR that someone would receive who is age 65 today and had been in the system for his entire life. Of course, this is a new system so 65 year olds today are actually not in it. We therefore calculate the MWR that would be received by a 25 year old who just entered the new system and stayed in it for his entire life. The biggest difference between these two groups is that the 25 -year old is in a younger cohort with lower mortality rates. Thus, these two individuals would experience the same MWR in Table 6 which uses period 
tables, but the 25-year old would have a much higher MWR--127.1\%--in Table 5, which cohortizes the mortality tables.

These numbers are only a rough approximation, for several reasons:

1. We are not sure what is the correct amount to subtract for D\&S insurance and administrative costs in the pre-retirement years. Most of this insurance is effectively covered by the pre-retirement accumulation, which is used for this purpose if the worker dies or becomes disabled. We base our estimate of $1.5 \%$ for $\mathrm{D} \& \mathrm{~S}$ insurance on the experience of several Latin American countries, which also top up the pre-retirement accumulated savings to provide D\&S insurance. We base our estimate of a net return of $4 \%$ per year on the assumption that the subsidized gross return is $4.5 \%$ and administrative costs are $.5 \%$ of assets per year which is equivalent to the ceiling on administrative costs set by regulations, of $8 \%$ of new contributions.

2. The time period under consideration for pre-and post-retirement for a worker who is age 25 today is over 70 years. For a 55 -year old worker today it is over 40 years. The period of deferment and the retirement period therefore vary, depending on age of worker today. And the period is very long, during which many changes are likely to occur. In particular, we do not know how interest rates will change over the next 70 years. Currently the term structure is flat, at $4 \%$, and we assume this will continue.

3. We also do not have accurate mortality tables. Israel has only period tables. The legally required rate for annuitants is a 3-year setback from the general population. Recently an actuaries' committee developed another period table that was supposed to be more accurate, but that has not yet been put into use. In this paper we use the actuaries' table; the MWR's are about 2\% higher than for the legally required table. In Table 7 we cohortize the actuaries' table, using the standard Canadian improvement factor. We carry out this cohortization for two representative workers--one who is age 25 today and plans to stay in the system for his entire life, and one who is age 65 today and theoretically has been in the system his entire life. Obviously, the MWR ratio turns out to be much higher--in fact, unsustainably high--for the worker who is age 25 today, because the mortality improvement factor has many more years in which to work.

4. According to the law, these pension rights that accumulate for each year of contributions are not legally binding. Instead, they can and indeed must be adjusted for financial sustainability as needed. These numbers imply that the promises being made to young workers today cannot be kept, and that there will be tremendous political pressures in the future to bail out the system even more than it is presently being bailed out. The need for more accurate mortality tables, including cohort tables, for companies, regulators and policy-makers to feed into these calculations, is obviously crucial, especially when long lasting commitments such as deferred annuities are under consideration. 


\section{Appendix C: Sources of Mortality Data}

\section{Canada}

- Population period table originated with the Canadian Life Table of 1991 (CLT91), available from the Society of Actuaries (SOA). This was projected ("aged") to 1999 by authors, using improvement factors (IF's) taken from the Canadian Pension Plan (CPP, see Table VII.B.2 of Office of Superintendent of financial Institutions, 1998). Formula was:

MortCLT91 proj99*(1-IF) $)^{(\text {age-65) }}=$ MortCLT91(1-IF $)^{8}$

where MortCLT91 is mortality for population period 1991 and MortCLTproj99 is mortality for population period 1991 projected to 1999

- Authors then used the CPP IF's to cohortize the 1999 period tables for the 1934 birth cohort, according to following formula, for each age:

MortCoh99=MortCLT91 proj99*(1-IF) ${ }^{\text {(age-65) }}=$ MortCLT91 $^{\text {(age-65+8) }}$

where MortCoh99 is mortality for population cohort age 65 in 1999.

- Annuitant period table was taken from IA83, Individual Annuitant Mortality Basic Table (SOA, 1983). Since annuitant mortality did not appear to change between 1983 and 1995, this was assumed by Kim and Sharp (1999) to represent period table for 1995. Authors "aged" this table to 1999 and cohortized using same CPP scale as for population. Formula was:

MortCoh99=MortPer99*(1-IF) $)^{(\text {age-65) }}$

- IF was taken from CPP scale and is same for population and annuitants.

- For sensitivity analysis we also obtain a different population cohort table by deriving IF from mortality data used in and supplied to us by Goss et al 1998. IF's implied by these data were lower and cohort mortality higher than with CPP data supplied by Kim and Sharp (see Appendix D for comparison).

US

- Population period and cohort table is from SSA 1999 Trustees' Report, scenario 2, pertaining to 1998 mortality, supplied by Jeffrey Brown.

- Annuitant cohort data were supplied by Jeffrey Brown (same data that were used in Brown, Mitchell and Poterba 2000), applied to birth cohort 1933 in 1998.

- Annuitant period tables are not available. Our table was reconstructed by authors assuming annuitant IF was same as population IF so period/cohort mortality ratios were same for population and annuitants.

- Population IF was derived by authors from ratio between period and cohort mortalities. Same IF is assumed for annuitants. Formula used for each age was:

MortCoh $=$ MortPer* $(1-\mathrm{IF})^{(\text {age-65) }}=>$

$\mathrm{IF}=1$ - (MortCoh/MortPer) $^{(1 /(\text { age-65)) }}$

- For sensitivity analysis we also use data based on and supplied by Goss et al 1998 for population period, cohort and IF, for years 1997-99. These data implied somewhat higher IF's than but similar cohort tables to BMP data (see Appendix D).

\section{Australia}

- Population period table is based on A95-97, prepared jointly by the Australian Bureau of Statistics and the Office of the Australian Government Actuary and published in 
ABS (1998). Authors projected this to 1998 using IF developed by ABS, as supplied by Knox 2000. Formula used, for each age, was:

MortPerA95-97* $(1-\mathrm{IF})^{2}=$ MortPerA98

where MortPerA95-97 is mortality of population period 1995-97 (taken as in 1996) and MortPerA98 is mortality of population period 1998.

- For population cohort table authors cohortized period table using IF developed by ABS.

- Australia has not yet developed its own annuitant tables. Annuitant period table is based on $60 \% \mathrm{IM} 80 / \mathrm{IF} 80$. IM/IF80 is a UK annuitant table from 1980, as reported in Institute of Actuaries and Faculty of Actuaries (1990). 60\% of this mortality is used to make it consistent with recent Australian annuitant experience and because it is the rate quoted in the Solvency Standard.

- Annuitant cohort table was constructed by authors assuming the same IF as for the general population.

- IF is from Population Projections 1997-2051, ABS (1998), based on analysis of past trends in mortality rates for the five underlying causes of death from 1967-96. We assumed same IF for population and annuitants.

UK

- Population cohort table comes from Government Actuary's Department (GAD65), as supplied by Murthi, Orszag and Orszag (1999).

- Population period table was derived from cohort table and annuitant IF, under assumption that population IF is same as annuitant IF.

- Annuitant period table is from Continuous Mortality Investigation Bureau (CMIR) Report No. 16 (http://www.actuaries.org.uk), which provides base tables about the experience of annuitants 1992. These were aged to 1999 using formula in CMIR 17, which presents IF's based on 20=year trend since 1975. "Pensioners" tables are used in this paper, rather than "annuitants" tables that were added only recently, on assumption that pensioners' tables were more likely to approximate experience in compulsory market, which is dominant group covered by this paper.

- Annuitant cohort table cohortizes this period table based on IF formula in CMIR 17.

- Formula for IF in CMIR 17 is:

$\mathrm{IF}=(1-\mathrm{RF})$, where RF (age,t) $=\mathrm{a}($ age $)+[1-\mathrm{a}(\text { age })]^{*}[1-\mathrm{f}(\text { age })]^{\mathrm{t} / 20}$

$\mathrm{a}($ age $)=1+(1-\mathrm{c})^{*}($ age- 110$) / 50$

$\mathrm{f}($ age $)=[(110$-age $) * \mathrm{~h}+($ age- 60$) * \mathrm{k}] / 50$, both for $60<$ age $<110$

$\mathrm{c}=.13, \mathrm{~h}=.55, \mathrm{k}=.29$

$\mathrm{t}=$ time elapsed since 1992

\section{Switzerland}

- Population period and cohort tables were provided by Breuer and Zweifel (2000) from Swiss Federal Office of Statistics data. Period table was from 1988-93. Authors "aged" this to 1998, using population IF as derived below. First population cohort table was published in 1998. Tables give probability of dying by 5 -year age intervals. Authors smoothed within 5-year intervals for cohort table.

- Annuitant period table for Pillar II for 1985 is from Koller 1998b. Authors "aged" it to 1998 and cohortized for 1933 birth cohort using Pillar II IF. 
- Annuitant period table for Pillar III for 1993 is from Koller 1998a. Authors "aged" it to 1998 and cohortized for 1933 cohort using Pillar III IF. IF without safety margin for insurance companies was used.

- IF's for population were derived by authors by comparing period table from 1988-93 with cohort mortality for 1998 according to following formula, for each age: MortCoh98=MortPer90*(1-IF $)^{(\text {age- } 65+8)}=>$ $\mathrm{IF}=1-(\text { MortCoh/MortPer })^{(1 /(\text { age-57) })}$

where MortPer90 is mortality of population period 1988-93 (taken as in 1990) and MortCoh98 is mortality of population cohort 1998.

- IF's for Pillars II and III are from Koller 1998a and b.

\section{Singapore}

- Singapore does not have its own mortality tables. Population period tables published by government group large age intervals together and hence were not appropriate for our purposes.

- Population period tables (A90 M and F) used are UK tables based on UK annuitant mortality experience in 1967-70 with mortality projected to 1990.

- Annuitant period table applies two-year set-back to A90. These tables are used by all insurance companies. However, recent data suggest that they overestimate annuitant mortality rates (underestimate survival) in Singapore.

- Tables were supplied by Chang 1999.

- Annuitant cohort tables and IF's are not available. For some runs authors applied Canadian IF to age period data to 1998 and cohortize.

\section{Chile}

- Population mortality table is calculated by the Instituto Nacional de Estadisticas (INE), 1996, based on 1992 Census with adjustments to 1996.

- Annuitant period table-RV98 - was recently developed, on basis of mortality experience of annuitants in AFP system 1983-96.

- Data were supplied by Callund 1999.

- No cohort tables or IF's are available. For some runs authors applied Canadian IF to age period data to 1998 and cohortize.

\section{Israel}

- Population period table is national table.

- Insurance regulators mandate 3-year displacement of population table to be used as annuitants' period table. But new table has been constructed by actuaries' committee set up by Ministry of Finance, which we use. This gives slightly lower mortality rates.

- Data were supplied by Spivak 1999.

- No cohort tables or IF's are available. For some runs we apply Canadian IF to cohortize. 


\section{Appendix D: Mortality Rates and Improvement Factors for US and Canada}

The wide variations in annual improvement factors (IF's) are illustrated in Table D1, adapted from Goss et al (1998), which compares IF's in different decades in Canada, US and Mexico. This table makes it clear that one must beware of projecting to the long run based on any short run experience.

Table D1. Average Annual Percentage Reductions in Death Rates for Ages over 65:

Canada, Mexico, and U.S.

\begin{tabular}{|c|c|c|c|c|c|c|}
\hline & \multicolumn{3}{|c|}{ Males } & \multicolumn{3}{c|}{ Females } \\
\hline Country & Canada & Mexico & U.S. & Canada & Mexico & U.S. \\
\hline $1900-10$ & -0.30 & & 0.11 & -0.47 & & 0.02 \\
\hline $1910-20$ & -0.38 & & 0.62 & -0.51 & & 0.53 \\
\hline $1920-30$ & -0.67 & & -0.50 & -0.32 & & 0.10 \\
\hline $1930-40$ & -0.24 & 0.29 & 0.02 & 0.33 & 0.29 & 0.38 \\
\hline $1940-50$ & 0.69 & 2.72 & 1.28 & 1.03 & 3.31 & 1.90 \\
\hline $1950-60$ & 0.35 & 1.80 & 0.09 & 1.48 & 1.63 & 0.78 \\
\hline $1960-70$ & 0.49 & 0.15 & 0.17 & 1.85 & 0.47 & 1.50 \\
\hline $1970-80$ & 0.80 & 0.46 & 1.51 & 1.67 & 1.77 & 2.10 \\
\hline $1980-90$ & 0.98 & 1.12 & 0.72 & 1.32 & 1.39 & 0.48 \\
\hline $1990-94$ & 0.97 & 0.28 & 0.41 & 1.36 & 1.17 & -0.24 \\
\hline Average & 0.21 & 1.04 & 0.54 & 0.82 & 1.45 & 1.09 \\
\hline
\end{tabular}

Source: Goss, Stephen C., Alice Wade, Felicitie Bell and Bernard Dussault. "Historical and Projected Mortality for Mexico, Canada, and the United States, North American Actuarial Journal, 2 (4): 108-126.

Tables D2 shows the change in improvement factors (IF), life expectancies and MWR's in moving from period to cohort tables that would have been implied by the Goss et al data, and compares these variables with data used in our study. For the age 65+ group, the Goss et al data imply an IF for the US that is larger than the Brown data that we adopted. In contrast, the Goss et al data imply an IF for Canada that is only half as large as the Kim and Sharp data used in our study. (However, for the US the cohort tables and cohort-based MWR's are very similar using the two sources).

Table D2: Life Expectancy, IF and MWR's Derived From Different Data Sources

\begin{tabular}{|c|c|c|c|c|}
\hline \multicolumn{5}{|c|}{ Males } \\
\hline & \multicolumn{2}{|c|}{ Canada } & \multicolumn{2}{|c|}{ US } \\
\hline & James and Song & Goss etal & James and Song & Goss etal \\
\hline Difference in LE, cohort - period & 0.9 & 0.7 & 0.2 & 0.5 \\
\hline Difference in MW, cohort - period & 3.0 & 1.9 & 0.7 & 1.4 \\
\hline Average annual IF, age 66-75 (\%) & 1.84 & 0.87 & 0.17 & 0.99 \\
\hline Population cohort MWR & 91.4 & 88.4 & 85.8 & 85.3 \\
\hline \multicolumn{5}{|c|}{ Females } \\
\hline & \multicolumn{2}{|c|}{ Canada } & \multicolumn{2}{|c|}{ US } \\
\hline & James and Song & Goss etal & James and Song & Goss etal \\
\hline Difference in LE, cohort - period & 1.4 & 1.4 & 0.5 & 0.6 \\
\hline Difference in MW, cohort - period & 3.7 & 2.6 & 0.8 & 1.0 \\
\hline Average annual IF, age 66-75 (\%) & 1.54 & 1.00 & -0.12 & 0.33 \\
\hline Population cohort MWR & 95.0 & 93.5 & 87.1 & 87.5 \\
\hline
\end{tabular}


Note to Table: James and Song's data for Canada were supplied by Kim and Sharp, and data for US were supplied by Brown. Goss et al provided us with their period mortality data. We cohortized their Canadian table based on period 1999, using improvement factor computed from periods 1997-99. We cohortized the Goss et al US table based on period 1998, using improvement factor computed from periods 1997-99.

While both sets of improvement projections for the US ultimately come from the SSA, they are based on period data gathered in different years and somewhat different methodologies, which results in different projections. Additionally, each insurance company keeps its own records privately. Discussions with actuaries at several companies indicate that mortality is projected to decrease, on average, about $1 \%$ per year for the $65+$ age group, while SSA projects about half of that. If the true improvement factor were $1 \%$ the MWR for the average population member in the US would reach 100\% (see Table 7). This has implications both for the public social security system and the private annuity system in the US. 
$\underline{\text { Male }}$

Age
65
66
67
68
69
70
71
72
73
74
75
76
77
78
79
80
85
95
105

\section{Appendix E1: Mortality Tables}

$$
\begin{aligned}
& \text { Canada } \\
& \text { population population annuitant } \\
& \text { period cohnuitant } \\
&
\end{aligned}
$$

US

population population annuitant Annuitant period cohort period cohort

$\begin{array}{llll}0.018 & 0.018 & 0.012 & 0.012 \\ 0.019 & 0.019 & 0.013 & 0.013 \\ 0.021 & 0.020 & 0.015 & 0.014 \\ 0.023 & 0.022 & 0.016 & 0.015 \\ 0.025 & 0.023 & 0.018 & 0.017 \\ 0.028 & 0.026 & 0.021 & 0.019 \\ 0.031 & 0.027 & 0.023 & 0.021 \\ 0.034 & 0.030 & 0.025 & 0.022 \\ 0.037 & 0.032 & 0.028 & 0.024 \\ 0.041 & 0.035 & 0.031 & 0.026 \\ 0.047 & 0.041 & 0.035 & 0.031 \\ 0.051 & 0.044 & 0.039 & 0.033 \\ 0.056 & 0.048 & 0.042 & 0.036 \\ 0.061 & 0.051 & 0.047 & 0.039 \\ 0.066 & 0.055 & 0.052 & 0.043 \\ 0.075 & 0.065 & 0.059 & 0.051 \\ 0.121 & 0.108 & 0.097 & 0.087 \\ 0.232 & 0.209 & 0.206 & 0.186 \\ & & 0.429 & 0.372\end{array}$

Australia

population population annuitant period

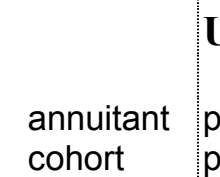

$$
\text { cohort }
$$

\begin{tabular}{lllll|llll}
65 & 0.017 & 0.017 & 0.014 & 0.014 & 0.021 & 0.021 & 0.015 & 0.015 \\
66 & 0.019 & 0.019 & 0.015 & 0.015 & 0.024 & 0.023 & 0.017 & 0.016 \\
67 & 0.021 & 0.020 & 0.016 & 0.016 & 0.026 & 0.025 & 0.019 & 0.018 \\
68 & 0.023 & 0.022 & 0.018 & 0.017 & 0.029 & 0.027 & 0.022 & 0.020 \\
69 & 0.026 & 0.024 & 0.019 & 0.018 & 0.032 & 0.029 & 0.024 & 0.022 \\
70 & 0.028 & 0.026 & 0.021 & 0.019 & 0.036 & 0.032 & 0.027 & 0.025 \\
71 & 0.031 & 0.028 & 0.023 & 0.020 & 0.040 & 0.035 & 0.031 & 0.027 \\
72 & 0.034 & 0.030 & 0.025 & 0.022 & 0.044 & 0.038 & 0.034 & 0.030 \\
73 & 0.038 & 0.032 & 0.027 & 0.023 & 0.049 & 0.041 & 0.038 & 0.033 \\
74 & 0.041 & 0.034 & 0.030 & 0.025 & 0.054 & 0.045 & 0.043 & 0.037 \\
75 & 0.046 & 0.038 & 0.032 & 0.027 & 0.060 & 0.049 & 0.048 & 0.040 \\
76 & 0.050 & 0.041 & 0.035 & 0.029 & 0.066 & 0.054 & 0.053 & 0.045 \\
77 & 0.055 & 0.045 & 0.038 & 0.031 & 0.073 & 0.059 & 0.058 & 0.049 \\
78 & 0.061 & 0.048 & 0.041 & 0.033 & 0.081 & 0.065 & 0.065 & 0.054 \\
79 & 0.068 & 0.053 & 0.045 & 0.035 & 0.089 & 0.071 & 0.071 & 0.059 \\
80 & 0.076 & 0.064 & 0.049 & 0.041 & 0.098 & 0.078 & 0.078 & 0.065 \\
85 & 0.126 & 0.119 & 0.074 & 0.070 & 0.151 & 0.120 & 0.121 & 0.101 \\
95 & 0.236 & 0.217 & 0.160 & 0.147 & 0.281 & 0.235 & 0.244 & 0.216 \\
105 & 0.295 & 0.263 & 0.313 & 0.280 & 0.484 & 0.453 & 0.390 & 0.374
\end{tabular}

$\begin{array}{llll}0.021 & 0.021 & 0.011 & 0.011 \\ 0.024 & 0.024 & 0.012 & 0.012 \\ 0.026 & 0.026 & 0.014 & 0.014 \\ 0.028 & 0.028 & 0.015 & 0.015 \\ 0.030 & 0.029 & 0.017 & 0.017 \\ 0.032 & 0.031 & 0.019 & 0.018 \\ 0.034 & 0.033 & 0.021 & 0.020 \\ 0.037 & 0.035 & 0.023 & 0.022 \\ 0.040 & 0.038 & 0.026 & 0.025 \\ 0.043 & 0.041 & 0.029 & 0.027 \\ 0.047 & 0.045 & 0.031 & 0.030 \\ 0.051 & 0.049 & 0.034 & 0.033 \\ 0.056 & 0.053 & 0.038 & 0.036 \\ 0.061 & 0.058 & 0.042 & 0.040 \\ 0.068 & 0.064 & 0.046 & 0.044 \\ 0.075 & 0.071 & 0.051 & 0.049 \\ 0.115 & 0.113 & 0.079 & 0.078 \\ 0.249 & 0.246 & 0.174 & 0.172 \\ 0.417 & 0.391 & 0.363 & 0.340\end{array}$

\section{UK}

population population annuitant Annuitant period cohort period cohort 


\section{Switzerland}

population population pillar II pillar II pillar III pillar III period cohort period cohort period cohort

age

65

66

67

68

69

70

71

72

73

74

75

76

77

78

79

80

85

95

105

$\begin{array}{ll}0.016 & 0.016 \\ 0.018 & 0.018 \\ 0.020 & 0.020 \\ 0.023 & 0.022 \\ 0.025 & 0.024 \\ 0.028 & 0.026 \\ 0.031 & 0.028 \\ 0.033 & 0.030 \\ 0.037 & 0.033 \\ 0.041 & 0.036 \\ 0.045 & 0.039 \\ 0.050 & 0.043 \\ 0.055 & 0.046 \\ 0.061 & 0.051 \\ 0.068 & 0.056 \\ 0.075 & 0.062 \\ 0.123 & 0.098 \\ 0.293 & 0.255\end{array}$

$\begin{array}{llll}0.014 & 0.014 & 0.009 & 0.009 \\ 0.015 & 0.015 & 0.010 & 0.010 \\ 0.017 & 0.016 & 0.011 & 0.011 \\ 0.018 & 0.018 & 0.012 & 0.011 \\ 0.020 & 0.019 & 0.014 & 0.012 \\ 0.022 & 0.020 & 0.015 & 0.014 \\ 0.024 & 0.022 & 0.017 & 0.015 \\ 0.026 & 0.024 & 0.019 & 0.016 \\ 0.029 & 0.026 & 0.021 & 0.018 \\ 0.032 & 0.028 & 0.024 & 0.019 \\ 0.035 & 0.030 & 0.027 & 0.021 \\ 0.039 & 0.033 & 0.030 & 0.023 \\ 0.043 & 0.036 & 0.033 & 0.025 \\ 0.048 & 0.039 & 0.037 & 0.028 \\ 0.054 & 0.043 & 0.041 & 0.030 \\ 0.060 & 0.047 & 0.046 & 0.033 \\ 0.099 & 0.071 & 0.078 & 0.054 \\ 0.237 & 0.156 & 0.202 & 0.134 \\ 1.000 & 1.000 & 0.421 & 0.286\end{array}$

Chile population annuitant period period
Singapore population annuitant

$$
\text { period period }
$$

age

65

66

67

68

69

70

71

72

73

74

75

76

77

78

79

80

85

95

105

\section{Israel}

population actuaries committee period period

\begin{tabular}{llll|l|l|l} 
ge & & & & & & \\
65 & 0.023 & 0.015 & 0.022 & 0.018 & 0.023 & 0.015 \\
66 & 0.026 & 0.016 & 0.024 & 0.020 & 0.026 & 0.017 \\
67 & 0.028 & 0.018 & 0.026 & 0.022 & 0.028 & 0.019 \\
68 & 0.031 & 0.020 & 0.028 & 0.024 & 0.031 & 0.021 \\
69 & 0.033 & 0.022 & 0.031 & 0.026 & 0.035 & 0.023 \\
70 & 0.036 & 0.024 & 0.034 & 0.028 & 0.038 & 0.025 \\
71 & 0.040 & 0.026 & 0.037 & 0.031 & 0.042 & 0.028 \\
72 & 0.043 & 0.029 & 0.040 & 0.034 & 0.047 & 0.031 \\
73 & 0.047 & 0.031 & 0.044 & 0.037 & 0.051 & 0.034 \\
74 & 0.052 & 0.035 & 0.048 & 0.040 & 0.057 & 0.037 \\
75 & 0.056 & 0.038 & 0.052 & 0.044 & 0.062 & 0.041 \\
76 & 0.061 & 0.042 & 0.057 & 0.048 & 0.068 & 0.045 \\
77 & 0.066 & 0.047 & 0.062 & 0.052 & 0.075 & 0.050 \\
78 & 0.072 & 0.052 & 0.067 & 0.057 & 0.082 & 0.055 \\
79 & 0.079 & 0.057 & 0.073 & 0.062 & 0.089 & 0.061 \\
80 & 0.085 & 0.062 & 0.079 & 0.067 & 0.098 & 0.067 \\
85 & 0.129 & 0.096 & 0.119 & 0.101 & 0.145 & 0.107 \\
95 & 0.278 & 0.221 & 0.249 & 0.217 & 0.269 & 0.235 \\
05 & 0.535 & 0.456 & 0.449 & 0.405 & 0.500 & 0.403
\end{tabular}




\section{$\underline{\text { Female }}$}

age

65

66

67

68

69

70

71

72

73

74

75

76

77

78

79

80

85

95

105
Canada

population population annuitant period cohort period cohort
US

population population annuitant Annuitant period cohort period cohort

\begin{tabular}{|c|c|c|c|c|c|c|c|c|}
\hline & $\begin{array}{l}\text { Australia } \\
\text { population } \\
\text { period }\end{array}$ & $\begin{array}{l}\text { population } \\
\text { cohort }\end{array}$ & $\begin{array}{l}\text { annuitant } \\
\text { period }\end{array}$ & $\begin{array}{l}\text { annuitant } \\
\text { cohort }\end{array}$ & $\begin{array}{l}\text { UK } \\
\text { population } \\
\text { period }\end{array}$ & $\begin{array}{l}\text { population } \\
\text { cohort }\end{array}$ & $\begin{array}{l}\text { annuitant } \\
\text { period }\end{array}$ & $\begin{array}{l}\text { Annuitant } \\
\text { cohort }\end{array}$ \\
\hline 65 & 0.009 & 0.009 & 0.007 & 0.007 & 0.012 & 0.012 & 0.009 & 0.009 \\
\hline 66 & 0.010 & 0.010 & 0.008 & 0.008 & 0.014 & 0.013 & 0.010 & 0.010 \\
\hline 67 & 0.011 & 0.011 & 0.009 & 0.008 & 0.015 & 0.015 & 0.012 & 0.011 \\
\hline 68 & 0.012 & 0.012 & 0.009 & 0.009 & 0.017 & 0.016 & 0.013 & 0.012 \\
\hline 69 & 0.014 & 0.013 & 0.011 & 0.010 & 0.019 & 0.018 & 0.015 & 0.014 \\
\hline 70 & 0.015 & 0.014 & 0.012 & 0.011 & 0.022 & 0.019 & 0.017 & 0.015 \\
\hline 71 & 0.017 & 0.015 & 0.013 & 0.012 & 0.024 & 0.021 & 0.019 & 0.017 \\
\hline 72 & 0.019 & 0.016 & 0.014 & 0.013 & 0.027 & 0.023 & 0.022 & 0.019 \\
\hline 73 & 0.021 & 0.018 & 0.016 & 0.014 & 0.030 & 0.025 & 0.024 & 0.021 \\
\hline 74 & 0.023 & 0.019 & 0.018 & 0.015 & 0.033 & 0.028 & 0.027 & 0.023 \\
\hline 75 & 0.026 & 0.023 & 0.020 & 0.018 & 0.037 & 0.031 & 0.030 & 0.026 \\
\hline 76 & 0.029 & 0.026 & 0.022 & 0.019 & 0.041 & 0.033 & 0.034 & 0.029 \\
\hline 77 & 0.033 & 0.029 & 0.025 & 0.021 & 0.045 & 0.037 & 0.038 & 0.032 \\
\hline 78 & 0.037 & 0.032 & 0.027 & 0.023 & 0.050 & 0.040 & 0.042 & 0.035 \\
\hline 79 & 0.042 & 0.036 & 0.030 & 0.026 & 0.056 & 0.045 & 0.047 & 0.039 \\
\hline 80 & 0.047 & 0.041 & 0.034 & 0.029 & 0.063 & 0.050 & 0.052 & 0.043 \\
\hline 85 & 0.086 & 0.079 & 0.056 & 0.052 & 0.107 & 0.084 & 0.085 & 0.071 \\
\hline 95 & 0.221 & 0.201 & 0.135 & 0.123 & 0.232 & 0.194 & 0.194 & 0.171 \\
\hline 105 & 0.349 & 0.307 & 0.275 & 0.242 & 0.367 & 0.344 & 0.357 & 0.343 \\
\hline
\end{tabular}


Switzerland

population population pillar II pillar II pillar III pillar III period cohort period cohort period cohort

age

65

66

67

68

69

70

71

72

73

74

75

76

77

78

79

80

85

95

105

0.007
0.008
0.009
0.010
0.012
0.013
0.014
0.016
0.018
0.021
0.023
0.026
0.029
0.034
0.038
0.043
0.082
0.255

0.007
0.008
0.009
0.010
0.011
0.012
0.013
0.015
0.016
0.018
0.020
0.022
0.024
0.028
0.031
0.035
0.062
0.201

0.005

0.006

0.006

0.006

0.007

0.007

0.008

0.010

0.011

0.013

0.018

0.020

0.023

0.027

0.031

0.055

0.173
0.015

0.005
0.006
0.006
0.006
0.006
0.007
0.007
0.008
0.009
0.010
0.012
0.013
0.015
0.016
0.018
0.020
0.030
0.083

$\begin{array}{ll}0.004 & 0.004 \\ 0.004 & 0.004 \\ 0.006 & 0.005 \\ 0.005 & 0.005 \\ 0.006 & 0.005 \\ 0.007 & 0.006 \\ 0.008 & 0.007 \\ 0.009 & 0.007 \\ 0.010 & 0.008 \\ 0.012 & 0.009 \\ 0.013 & 0.010 \\ 0.016 & 0.011 \\ 0.018 & 0.013 \\ 0.021 & 0.015 \\ 0.024 & 0.017 \\ 0.028 & 0.019 \\ 0.060 & 0.039 \\ 0.209 & 0.154 \\ 0.458 & 0.396\end{array}$

Israel

Singapore

population annuitant period period

population annuitant period period

population actuaries committee period period

\begin{tabular}{ccc|cc|cc} 
age & & & & & & \\
65 & 0.015 & 0.008 & 0.011 & 0.009 & 0.017 & 0.010 \\
66 & 0.016 & 0.009 & 0.012 & 0.010 & 0.019 & 0.011 \\
67 & 0.018 & 0.010 & 0.013 & 0.011 & 0.021 & 0.012 \\
68 & 0.019 & 0.011 & 0.015 & 0.012 & 0.024 & 0.013 \\
69 & 0.021 & 0.012 & 0.016 & 0.013 & 0.026 & 0.015 \\
70 & 0.023 & 0.014 & 0.018 & 0.015 & 0.029 & 0.017 \\
71 & 0.025 & 0.015 & 0.020 & 0.016 & 0.033 & 0.019 \\
72 & 0.028 & 0.017 & 0.022 & 0.018 & 0.036 & 0.021 \\
73 & 0.031 & 0.019 & 0.025 & 0.020 & 0.040 & 0.023 \\
74 & 0.034 & 0.021 & 0.027 & 0.022 & 0.045 & 0.025 \\
75 & 0.037 & 0.024 & 0.030 & 0.025 & 0.050 & 0.028 \\
76 & 0.040 & 0.027 & 0.033 & 0.027 & 0.056 & 0.031 \\
77 & 0.044 & 0.030 & 0.037 & 0.030 & 0.063 & 0.035 \\
78 & 0.049 & 0.033 & 0.041 & 0.033 & 0.070 & 0.039 \\
79 & 0.053 & 0.037 & 0.045 & 0.037 & 0.078 & 0.043 \\
80 & 0.058 & 0.040 & 0.050 & 0.041 & 0.087 & 0.047 \\
85 & 0.091 & 0.068 & 0.082 & 0.067 & 0.138 & 0.078 \\
95 & 0.217 & 0.181 & 0.203 & 0.171 & 0.271 & 0.186 \\
105 & 0.463 & 0.431 & 0.422 & 0.372 & 0.500 & 0.340
\end{tabular}




\section{Appendix E2: Improvement Factors}

Male

\begin{tabular}{|c|c|c|c|c|c|c|c|}
\hline age & Canada & US & Australia & UK & $\begin{array}{c}\text { Switzerland - } \\
\text { population }\end{array}$ & $\begin{array}{c}\text { Switzerland - } \\
\text { Pillar II }\end{array}$ & $\begin{array}{c}\text { Switzerland - Pillar } \\
\text { III, without safety } \\
\text { margin }\end{array}$ \\
\hline 65 & 0.021 & & 0.021 & 0.029 & 0.027 & 0.014 & 0.027 \\
\hline 66 & 0.021 & -0.018 & 0.021 & 0.027 & 0.022 & 0.014 & 0.026 \\
\hline 67 & 0.021 & -0.005 & 0.021 & 0.026 & 0.018 & 0.014 & 0.026 \\
\hline 68 & 0.021 & 0.001 & 0.021 & 0.025 & 0.017 & 0.014 & 0.026 \\
\hline 69 & 0.021 & 0.004 & 0.021 & 0.025 & 0.016 & 0.014 & 0.026 \\
\hline 70 & 0.018 & 0.005 & 0.020 & 0.024 & 0.016 & 0.015 & 0.025 \\
\hline 71 & 0.018 & 0.006 & 0.020 & 0.023 & 0.016 & 0.015 & 0.025 \\
\hline 72 & 0.018 & 0.007 & 0.020 & 0.022 & 0.017 & 0.015 & 0.025 \\
\hline 73 & 0.018 & 0.006 & 0.020 & 0.021 & 0.015 & 0.015 & 0.024 \\
\hline 74 & 0.018 & 0.006 & 0.020 & 0.020 & 0.014 & 0.016 & 0.024 \\
\hline 75 & 0.013 & 0.005 & 0.018 & 0.019 & 0.014 & 0.016 & 0.023 \\
\hline 76 & 0.013 & 0.005 & 0.018 & 0.018 & 0.014 & 0.016 & 0.023 \\
\hline 77 & 0.013 & 0.004 & 0.018 & 0.018 & 0.015 & 0.016 & 0.022 \\
\hline 78 & 0.013 & 0.004 & 0.018 & 0.017 & 0.013 & 0.016 & 0.022 \\
\hline 79 & 0.013 & 0.004 & 0.018 & 0.016 & 0.013 & 0.016 & 0.022 \\
\hline 80 & 0.009 & 0.003 & 0.011 & 0.015 & 0.013 & 0.016 & 0.021 \\
\hline 81 & 0.009 & 0.003 & 0.011 & 0.014 & 0.013 & 0.016 & 0.020 \\
\hline 82 & 0.009 & 0.003 & 0.011 & 0.014 & 0.013 & 0.016 & 0.020 \\
\hline 83 & 0.009 & 0.002 & 0.011 & 0.013 & 0.012 & 0.016 & 0.019 \\
\hline 84 & 0.009 & 0.001 & 0.011 & 0.012 & 0.011 & 0.016 & 0.019 \\
\hline 85 & 0.006 & 0.001 & 0.003 & 0.012 & 0.011 & 0.016 & 0.018 \\
\hline 86 & 0.006 & 0.000 & 0.003 & 0.011 & 0.011 & 0.016 & 0.018 \\
\hline 87 & 0.006 & 0.000 & 0.003 & 0.010 & 0.011 & 0.016 & 0.017 \\
\hline 88 & 0.006 & 0.000 & 0.003 & 0.010 & 0.010 & 0.016 & 0.017 \\
\hline 89 & 0.006 & 0.000 & 0.003 & 0.009 & 0.009 & 0.016 & 0.016 \\
\hline 90 & 0.004 & 0.000 & 0.005 & 0.009 & 0.009 & 0.015 & 0.016 \\
\hline 91 & 0.004 & 0.000 & 0.005 & 0.008 & 0.008 & 0.015 & 0.015 \\
\hline 92 & 0.004 & 0.000 & 0.005 & 0.007 & 0.008 & 0.015 & 0.015 \\
\hline 93 & 0.004 & 0.000 & 0.005 & 0.007 & 0.007 & 0.014 & 0.014 \\
\hline 94 & 0.004 & 0.000 & 0.005 & 0.006 & 0.005 & 0.014 & 0.014 \\
\hline 95 & 0.004 & 0.000 & 0.003 & 0.006 & 0.005 & 0.014 & 0.013 \\
\hline 96 & 0.004 & 0.001 & 0.003 & 0.005 & 0.004 & 0.014 & 0.013 \\
\hline 97 & 0.004 & 0.001 & 0.003 & 0.005 & 0.004 & 0.014 & 0.013 \\
\hline 98 & 0.004 & 0.001 & 0.003 & 0.004 & 0.004 & 0.014 & 0.012 \\
\hline 99 & 0.004 & 0.001 & 0.003 & 0.004 & 0.003 & 0.014 & 0.012 \\
\hline 100 & 0.004 & 0.001 & & 0.004 & & 0.014 & 0.011 \\
\hline 101 & 0.004 & 0.001 & & 0.003 & & 0.014 & 0.011 \\
\hline 102 & 0.004 & 0.001 & & 0.003 & & 0.014 & 0.011 \\
\hline 103 & 0.004 & 0.001 & & 0.002 & & 0.014 & 0.010 \\
\hline 104 & 0.004 & 0.002 & & 0.002 & & & 0.010 \\
\hline 105 & 0.004 & 0.002 & & 0.002 & & & 0.010 \\
\hline 106 & 0.004 & 0.002 & & 0.001 & & & 0.009 \\
\hline 107 & 0.004 & 0.002 & & 0.001 & & & 0.009 \\
\hline 108 & 0.004 & 0.002 & & 0.001 & & & 0.009 \\
\hline 109 & 0.004 & 0.002 & & 0.000 & & & 0.008 \\
\hline 110 & 0.004 & 0.002 & & 0.000 & & & 0.008 \\
\hline
\end{tabular}




\section{Female}

age Canada US Australia UK

$$
65
$$$$
66
$$

$$
\begin{aligned}
& 66 \\
& 67 \\
& 68
\end{aligned}
$$

$$
68
$$

$$
69
$$$$
\begin{aligned}
& 69 \\
& 70
\end{aligned}
$$

$$
71
$$

$$
72
$$

$$
73
$$

$$
\begin{aligned}
& 74 \\
& 75
\end{aligned}
$$

$$
76
$$$$
77
$$

$$
\begin{aligned}
& 78 \\
& 79
\end{aligned}
$$

$$
\begin{aligned}
& 78 \\
& 79 \\
& 80
\end{aligned}
$$

8

8

83

84

$$
85
$$

$$
\begin{aligned}
& 87 \\
& 88 \\
& 89
\end{aligned}
$$

$$
\begin{aligned}
& 89 \\
& 90
\end{aligned}
$$

$$
90
$$$$
92
$$

$$
\begin{aligned}
& 92 \\
& 93
\end{aligned}
$$

\section{5}

96
97$$
98
$$ \\ 98
99}

$\begin{array}{lll}104 & 0.010 & 0.004\end{array}$

$\begin{array}{lll}105 & 0.010 & 0.004\end{array}$

$\begin{array}{lll}106 & 0.010 & 0.003\end{array}$

$\begin{array}{lll}107 & 0.010 & 0.003\end{array}$

$\begin{array}{lll}108 & 0.010 & 0.003\end{array}$

$\begin{array}{lll}109 & 0.010 & 0.003\end{array}$

$\begin{array}{lll}110 & 0.010 & 0.003\end{array}$

$\begin{array}{lll}0.016 & 0.029 & 0.026 \\ 0.016 & 0.027 & 0.017 \\ 0.016 & 0.026 & 0.013 \\ 0.016 & 0.025 & 0.011 \\ 0.016 & 0.025 & 0.011 \\ 0.019 & 0.024 & 0.011 \\ 0.019 & 0.023 & 0.012 \\ 0.019 & 0.022 & 0.014 \\ 0.019 & 0.021 & 0.013 \\ 0.019 & 0.020 & 0.013 \\ 0.012 & 0.019 & 0.013 \\ 0.012 & 0.018 & 0.014 \\ 0.012 & 0.018 & 0.016 \\ 0.012 & 0.017 & 0.015 \\ 0.012 & 0.016 & 0.014 \\ 0.010 & 0.015 & 0.014 \\ 0.010 & 0.014 & 0.015 \\ 0.010 & 0.014 & 0.016 \\ 0.010 & 0.013 & 0.015 \\ 0.010 & 0.012 & 0.014 \\ 0.004 & 0.012 & 0.014 \\ 0.004 & 0.011 & 0.014 \\ 0.004 & 0.010 & 0.015 \\ 0.004 & 0.010 & 0.013 \\ 0.004 & 0.009 & 0.012 \\ 0.005 & 0.009 & 0.012 \\ 0.005 & 0.008 & 0.012 \\ 0.005 & 0.007 & 0.012 \\ 0.005 & 0.007 & 0.010 \\ 0.005 & 0.006 & 0.009 \\ 0.003 & 0.006 & 0.008 \\ 0.003 & 0.005 & 0.007 \\ 0.003 & 0.005 & 0.007 \\ 0.003 & 0.004 & 0.006 \\ 0.003 & 0.004 & 0.006 \\ & 0.004 & \\ & 0.003 & \\ & 0.003 & \\ & 0.002 & \\ & 0.002 & \\ & 0.002 & \\ & 0.001 & \\ & 0.001 & \\ & 0.001 & \\ & 0.000 & \\ & 0.000 & \\ & & \end{array}$
Switzerland - Switzerland - Switzerland - Pillar population Pillar II III, without safety $\begin{array}{ccc} & & \text { margin } \\ 0.026 & 0.022 & 0.027\end{array}$ 0.027 0.028 0.028 0.028 0.028 0.028 0.028 0.028 0.028 0.028 0.028 0.027 0.027 0.027 0.026 0.025 0.024 0.024 0.023 0.022 0.021 0.020 0.018 0.017 0.016 0.015 0.013 0.012 0.011 0.010 0.009 0.008 0.007 0.007 0.006 0.005 0.005 0.004 0.004 0.004 0.003 0.003 0.003 0.002 0.002 
Footnote:

For details on sources of mortality data, see Appendix C. Improvement factors are from:

Canada

Annual Percentage Mortality Improvement Factors, Canada Pension Plan: Seventeenth

Annual Report, taken from Table VII.B.2 of Office of the Superintendent of Financial

Institutions (1998), as reproduced in Appendix A-5, Kim and Sharp (1999).

\section{Australia}

Projected annual rates of change in mortality rates from 1997, from ABS (1998), Population Projections 1997-2051, as reproduced in Table 9, Knox (2000).

\section{Switzerland}

Authors' calculation for population IF is based on population period 1988-93 (taken as in year 1990) and cohort 1993 that was age 65 in 1998. Cohort 1933 mortality table was smoothed before IF calculation.

Annuitant IF is from Koller 1998a and b.

\section{US}

Authors' calculation using population period and cohort mortality 1998 from SSA 1999 Trustee's Report, scenario 2, supplied by Brown.

\section{UK}

Derived from formula in CMIR, Report No. 17.

Authors assume the improvement factors for population and annuitants are the same in all countries except Switzerland. 


\section{Appendix F}

\section{Term Structure of Government Rates}

\begin{tabular}{|c|c|c|c|c|c|c|c|c|c|}
\hline Year & Canada & US & Australia & UK & UK(real) & Switzerland & Singapore & Chile & Israel \\
\hline 0 & 4.63 & 5.52 & 4.67 & 4.94 & 3.28 & 2.08 & 2.38 & 6.88 & 4.00 \\
\hline 1 & 5.43 & 5.52 & 4.67 & 4.94 & 3.28 & 2.08 & 2.38 & 6.88 & 4.00 \\
\hline 2 & 5.35 & 5.55 & 4.69 & 4.94 & 3.28 & 2.08 & 2.38 & 6.84 & 4.00 \\
\hline 3 & 5.53 & 5.56 & 4.70 & 4.89 & 2.73 & 2.08 & 2.88 & 6.82 & 4.00 \\
\hline 4 & 5.55 & 5.56 & 4.74 & 4.85 & 2.46 & 2.13 & 3.39 & 6.75 & 4.00 \\
\hline 5 & 5.58 & 5.60 & 4.80 & 4.81 & 2.30 & 2.53 & 3.89 & 6.72 & 4.00 \\
\hline 6 & 5.64 & 5.63 & 4.89 & 4.77 & 2.19 & 2.53 & 4.15 & 6.66 & 4.00 \\
\hline 7 & 5.70 & 5.65 & 4.99 & 4.74 & 2.11 & 2.53 & 4.41 & 6.58 & 4.00 \\
\hline 8 & 5.69 & 5.68 & 5.00 & 4.71 & 2.06 & 2.53 & 4.53 & 6.53 & 4.00 \\
\hline 9 & 5.68 & 5.74 & 5.04 & 4.68 & 2.01 & 2.53 & 4.65 & 6.50 & 4.00 \\
\hline 10 & 5.67 & 5.77 & 5.07 & 4.66 & 1.97 & 2.71 & 4.76 & 6.49 & 4.00 \\
\hline 11 & 5.69 & 5.79 & 5.09 & 4.63 & 1.94 & 2.71 & 4.76 & 6.48 & 4.00 \\
\hline 12 & 5.71 & 5.81 & 5.13 & 4.61 & 1.92 & 2.71 & 4.76 & 6.48 & 4.00 \\
\hline 13 & 5.73 & 5.83 & 5.13 & 4.59 & 1.90 & 2.71 & 4.76 & 6.46 & 4.00 \\
\hline 14 & 5.75 & 5.84 & 5.13 & 4.57 & 1.88 & 2.71 & 4.76 & 6.44 & 4.00 \\
\hline 15 & 5.77 & 5.85 & 5.13 & 4.56 & 1.86 & 2.71 & 4.76 & 6.43 & 4.00 \\
\hline 16 & 5.79 & 5.86 & 5.13 & 4.54 & 1.85 & 2.71 & 4.76 & 6.42 & 4.00 \\
\hline 17 & 5.81 & 5.87 & 5.13 & 4.53 & 1.84 & 4.05 & 4.76 & 6.40 & 4.00 \\
\hline 18 & 5.84 & 5.87 & 5.13 & 4.52 & 1.83 & 4.05 & 4.76 & 6.38 & 4.00 \\
\hline 19 & 5.86 & 5.88 & 5.13 & 4.51 & 1.82 & 4.05 & 4.76 & 6.37 & 4.00 \\
\hline 20 & 5.88 & 5.88 & 5.13 & 4.50 & 1.81 & 4.05 & 4.76 & 6.35 & 4.00 \\
\hline 21 & 5.87 & 5.88 & 5.13 & 4.50 & 1.80 & 4.05 & 4.76 & 6.35 & 4.00 \\
\hline 22 & 5.86 & 5.88 & 5.13 & 4.49 & 1.80 & 4.05 & 4.76 & 6.35 & 4.00 \\
\hline 23 & 5.85 & 5.88 & 5.13 & 4.49 & 1.79 & 4.12 & 4.76 & 6.35 & 4.00 \\
\hline 24 & 5.84 & 5.88 & 5.13 & 4.49 & 1.78 & 4.12 & 4.76 & 6.35 & 4.00 \\
\hline 25 & 5.83 & 5.87 & 5.13 & 4.49 & 1.78 & 4.12 & 4.76 & 6.35 & 4.00 \\
\hline 26 & 5.83 & 5.86 & 5.13 & 4.49 & 1.78 & 4.12 & 4.76 & 6.35 & 4.00 \\
\hline 27 & 5.82 & 5.85 & 5.13 & 4.49 & 1.78 & 4.12 & 4.76 & 6.35 & 4.00 \\
\hline 28 & 5.81 & 5.84 & 5.13 & 4.49 & 1.78 & 4.23 & 4.76 & 6.35 & 4.00 \\
\hline 29 & 5.80 & 5.83 & 5.13 & 4.49 & 1.78 & 4.23 & 4.76 & 6.35 & 4.00 \\
\hline 30 & 5.79 & 5.83 & 5.13 & 4.49 & 1.78 & 4.23 & 4.76 & 6.35 & 4.00 \\
\hline
\end{tabular}

Source: Country studies cited in fn 1 . 


\section{REFERENCES}

Ausubel, Lawrence, 1991. "The Failure of Competition in the Credit Card Market." American Economic Review. 81 (1), 50-81.

Attanasio, Orazio and Hilary Hoynes. 1995. "Differential Mortality and Wealth Accumulation. NBER working Paper 5126.

Blake, David. 1999. "Annuity Markets: Problems and Solutions." The Geneva Papers on Risk and Insurance. 24 (3) 358-75.

Bongaarts, John and Rodolfo A. Bulatao, eds. 2001. Beyond Six Billion: Forecasting the World's Population. Washington DC: National Academy Press.

Breuer, Michael and Peter Zweifel. 1999. "Annuity Products in Switzerland." Report for World Bank Research Project."

Brown, Jeffrey R. 2000. "Differential Mortality and the Value of Individual Account Retirement Annuities.” NBER Working Paper No. 7560.

Brown, Jeffrey R., Olivia S. Mitchell and James M. Poterba. 2000. "Mortality Risk, Inflation Risk, and Annuity Products.” NBER Working Paper 7812.

Callund, Jonathan. 1999. "The Annuity Market in Chile." Report for World Bank Annuity Research Project.

Chang, Chiu-Cheng. 1999. “The Annuity Market in Singapore.” Report for World Bank Annuity Research Project.

Davis, E. Philip. 2001. "Portfolio Regulation of Life Insurance Companies and Pension Funds." Working paper available from Davis at Brunel University, London, UK.

Davis, E.P. and Steil, B. 2000. Institutional Investors. MIT Press. Cambridge, MA.

Doyle, Suzanne, Olivia Mitchell and John Piggott. 2001. "Annuity Values in Defined Contribution Retirement Systems: The Case of Singapore and Australia." Draft.

Goss, Stephen, Alice Wade, Felicitie Bell and Bernard Dussault. 1998. "Historical and Projected Mortality for Mexico, Canada, and the United States." North American Actuarial Journal. 2 (4) 108-126.

Finkelstein, Amy and James Poterba. 1999. "The Market for Individual Annuity Products in the United Kingdom.” NBER Working Paper. N. 7168.

Finkelstein, Amy and James Poterba. 2000. "Adverse Selection in Insurance Markets: Policyholder Evidence from the UK Annuity Market". NBER Working Paper. 
Robert Friedland. 1998. "Life Expectancy in the Future: A Summary of a Discussion Among Experts.” North American Actuarial Journal, v. 2, \#4, 48-63.

Hug, Mark. 1999. "Immediate Annuity Pricing Strategies.” Paper prepared for World Bank Annuities Workshop, June 1999.

James, Estelle and Dimitri Vittas. 1999a. "The Decumulation (Payout) Phase of Defined Contribution Pillars." Presented at APEC meeting, Chile, 1999 and World Bank Policy Research Discussion Paper No. 2464, 2000.

James, Estelle and Dimitri Vittas. 1999b. "Annuities Markets in Comparative Perspective: Do Consumers Get Their Money's Worth?" Conference on New Ideas for Old Age Security, World Bank and World Bank Policy Research Discussion Paper No. 2493, 2000.

Kim, Hyun Tae and Keith Sharp. 1999. "Annuities in Canada." Report prepared for the World Bank Annuity Research Project.

Knox, David. 1999. "The Australian Annuity Market." Report for World Bank Annuity Research Project and World Bank Discussion Paper 2000.

Koller, Michael. 1998a. "Methodik zur Konstruktin von Generationentafeln.” May 1.

Koller, Michael. 1998b. "Reservationspolitik von Pensionskassen und die Altersrentenproblematik.” Herrliberg, July 1.

Laurence, Emily. 1991. "Poverty and the Rate of Time Preference: Evidence from Panel Data." Journal of Political Economy. 99 (1), 54-77.

LIMRA. 1998. "Product Design Series: Immediate Annuities." Windsor, CT: LIMRA International.

Mitchell, Olivia, James Poterba, Mark Warshawsky and Jeffrey Brown. 1999. "New Evidence on the Money's Worth of Individual Annuities". American Economic Review. 89 (5), 1299-1318.

Murthi, Mamta, J. Michael Orszag and Peter Orszag. 1999. "The Value for Money of Annuities in the UK: Theory, Experience and Policy." Report for World Bank Annuity Project and Centre for Pensions and Social Insurance Research Report, 1999-09.

Murthi, Mamta, J. Michael Orszag and Peter Orszag. 2000. "Annuity Margins in the UK". Centre for Pensions and Social Insurance Research Report, 2000-22. Forthcoming in OECD volume. 
Palacios, Robert and Rafael Rofman. 2000. "Annuity Market and Benefit Design in MultiPillar Pension Schemes: Experience and Lessons form Four Latin American Countries." World Bank Discussion Paper.

Plender, John. 2000. “Equitable’s Fatal Flaws”, Financial Times, Dec. 15.

Poterba, James. 1997. The History of Annuities in the United States. Working Paper No. 6001. Cambridge MA: NBER

Poterba, James and Mark Warshawsky. 2000. "The Costs of Annuitizing Retirement Payouts from Individual Accounts."

Queisser, Monika and Dimitri Vittas. 2000. The Swiss Pension System. World Bank and OECD Discussion Paper, in process.

Spivak, Avia. 1999. "Pension Reform in Israel and Money's Worth of Pensions and Annuities." Report for World Bank Annuity Research Project and World Bank Discussion Paper forthcoming 2001.

Thaler, Richard. 1994. "Some Empirical Evidence on Dynamic Inconsistency." In R. Thaler, ed. Quasi-Rational Economics. New York: Russell Sage Foundation: 130.

The Economist. 2000. "Trust Betrayed.” Dec. 23.

Treaster, Joseph. 2001. "Berkshire Hathaway Faces A Tough Insurance Market." New York Times. March 12, C10.

Townsend, Frederick. 1998 and 2000. National Underwriter. Nov. 7, 2000; June 1, 1998.

Tuljapurkar and Carl Boe. 1998. "Mortality Change and Forecasting: How Much and How Little Do We Know?” North American Actuarial Journal. 2 (4), 13-47.

Wadsworth, Mike, Alec Findlater and Tom Boardman. 2001. Reinventing Annuities. presented to Staple Inn Actuarial Society, London.

Wall Street Journal. 1995. "Offered a Lump Sum, Many Retirees Blow It and Risk Their Future." July 31. p. A1.

Wall Street Journal. 1998. "Thriving Industry Buys Insurance Settlements from Injured Plaintiffs.” Feb. 25. p. A1.

Warner, John T. and Saul Pleeter. 2001. "The Personal Discount Rate: Evidence from Military Downsizing Programs.” American Economic Review. 91 (1), 33-53 


\section{ENDNOTES}

1 Unless otherwise noted, the data we draw on (regarding payouts, interest rates and mortality rates) were collected as part of an annuities market project at the World Bank. Country studies were done in 1999 by David Knox-Australia, Hyman Tae Kim and Keith P. Sharp-Canada, Jonathan Callund-Chile, Avia Spivak-Israel, Chiu-Cheng Chan-Singapore, Michael Brewer and Peter Zweifel-Switzerland and Mamta Murthi, J. Michael Orszag and Peter Orszag-U.K. An earlier version of this paper presented at the World Ban Pension Research Conference, September 1999, also drew on these reports (James and Vittas 1999b). The numbers given there differ slightly from the numbers in this paper for several reasons: In some cases we crosschecked the data and modified them. In this paper we used a uniform annuity calculator supplied by Michael Orszag whereas the separate papers each used somewhat different calculators. We assumed annuity payments were made monthly in arrears while some of the reports assumed payments in advance, etc. For Switzerland we were able to draw on published data rather than the unpublished confidential data that Breuer and Zweifel used (see Koller 1998a and b). For the UK we used corrected period mortality tables and improvement factors. We also used a payout $2.5 \%$ higher than the payout given in Murthi, Orszag, and Orszag (1999) for 10,000 pounds, to take account of the scale economies in purchasing $\$ 100,000$ and our switch to monthly payments in arrears. For the US we used data supplied by Jeffrey Brown, to ensure comparability with Brown, Mitchell and Poterba 2000 and Mitchell, Poterba, Warshawsky and Brown 1999. Their population numbers originated with the Social Security Administration trustees' report and their annuitant data with tables of the Society of Actuaries.

${ }^{2}$ For a more qualitative discussion of how countries have dealt with disability and survivors annuities see James and Vittas 1999a.

3 The US is an exception here. The average population member in the US (unlike most other countries) has an MWR $<90 \%$, largely because of the very low rate of mortality improvement imputed in the US. For the annuitant group, the MWR is $97-98 \%$, since the below-average rate of mortality improvement is offset by above-average selection.

${ }^{4}$ Finkelstein and Poterba 1999 compare the UK voluntary and compulsory markets, based primarily on data from one large annuity supplier.

${ }^{5}$ Pillar II now has 670,000 pension beneficiaries, only half as many as Pillar I. However, over 3 million workers are covered by Pillar II in the accumulation stage, many of them new entrants to the system when it became mandatory in 1985, so the number of beneficiaries and the money flowing into annuities are expected to grow steeply as Pillar II matures. For further details about the Swiss system see Queisser and Vittas 2000.

${ }^{6}$ In Chile the insurance company chosen by the AFP gives the disabled or surviving beneficiary a lump sum which she can then turn into a gradual withdrawal or an annuity with the company of her own choice. In contrast, Argentina gave workers a compensatory pension paid by the government for the past service, instead of a bono that could be used to 
finance a private annuity. And in Argentina disability and survivors benefits are provided by insurance companies linked to the worker's pension fund, without an arms-length transaction. The annuity market in Argentina has been much slower to develop.

7 For most countries we use a $10 \mathrm{YG}$ beginning at age 65 . For Singapore we use a $15 \mathrm{YG}$ beginning at age 62 , because the CPF annuity must begin exactly at age 62 and the $15 \mathrm{YG}$ is most common in order to satisfy the "return of capital" requirement. According to CPF rules, the premium is paid at age 55 and the annuity is deferred. In calculating the MWR, we add 7 years of interest to the premium paid at age 55, using the 7 -year bond rate, to obtain the age-62 cost of the annuity, which is $\$ 100,000$. (The premium is returned if the annuitant dies before age 62). For further details on Singapore see Appendix A.

${ }^{8}$ Differences in payouts and MWR among different products in the UK are discussed in detail in Finkelstein and Poterba 2000. Their numbers are slightly different from ours due to slightly different dates, sample of companies, interest rates and methodologies. However, the relations among products and the analytic and policy implications are unaffected by these small differences.

${ }^{9}$ Poland and Hungary also require annuitization based on unisex tables in their new mandatory funded system, while most Latin American countries permit either gradual withdrawals or annuitization and gender-specific tables are allowed.

${ }^{10}$ The expansion of the annuity market, which provides long-term financial instruments for consumers, may create a derived demand for other kinds of long-term instruments for insurance companies to hold, backing the annuities. For example, in Chile, AFP's and insurance companies, whose main products are annuities, are the major holders of medium term home mortgage bonds, an instrument that developed after the pension reform. Singapore is encouraging the issuance of long-term public authority and corporate bonds, in part to facilitate the development of the annuities market.

${ }^{11}$ These relationships held in mid-1999 when our data on payouts and interest rates were gathered. The yield curve changes over time. In 2000 yield curves were flatter in Singapore and Switzerland than they were in 1999. These patterns depend on current monetary policy and expectations about future inflation and interest rates, among other factors.

${ }^{12}$ Peru also uses the Chilean data. Argentina uses a table that was originally developed by the Society of Actuaries in the US, based on annuitants' mortality in the US in the 1940's, with adjustments to fit current Argentine conditions. In both these cases annuitant projections are complicated by the fact that only formal sector workers are covered by the pension system that generates a demand for annuities so companies must deal with selection into the system, which changes through time, as well as selection into the group of annuitants (Palacios and Rofman 2000).

${ }^{13}$ Thus private annuity companies face similar risks regarding future mortality that public defined benefit systems have long faced. The private annuity system, however, has three advantages over public systems in this regard: First, the public system usually begins to 
make DB promises to the worker from the date he enters the labor force, so the period at risk may exceed 70 years, while private annuities are more likely sold after the age of 60, leaving a much shorter time span and less uncertainty about expected longevity. Second, the private sector can adjust the terms of new annuities sold much more rapidly than public systems can adjust its DB formula, so new information can be incorporated before a large unfunded liability is accumulated. And third, the private sector has a well established system of laws (regarding rights or policy-holders, creditors and stockholders) that govern who bears the cost of unexpected outcomes - the intergenerational transfers may ultimately occur in the form of capital gains and losses to different cohorts of stockholders. In contrast, public defined benefit promises can be viewed as an incomplete contract, in which ex post political power determines who (old versus young, pensioners versus workers) bears this burden.

14 The discount rate varied by context and individual characteristics: it was lower for older workers with large sums at stake and higher for those with less education and more dependents. Consistent with this study is the fact that many consumers borrow from their credit card companies at rates of $18 \%$ or more, and that recipients of annuities from divorce and personal injury settlements often sell these deferred rights to firms that have sprung up to buy them, at immediate prices implying a discount rate of about $21 \%$. See Warner and Pleeter 2001. Corroborating evidence is found in Ausubel 1991, Laurance 1991, Thaler 1994 and Wall Street Journal 1995 and 1998.

15 Adverse selection is commonly ascribed to asymmetric information and cited as an instance of market failure. However, another possible explanation may be that voluntary annuities are a "luxury" good with a high income elasticity of demand so wealthy people are disproportionate buyers and they also happen to have greater longevity. This "passive" adverse selection stemming from the correlation of income and wealth with longevity and annuity purchases does not imply market failure because its causes are observable to the insurance company as well as the individual, hence its policy implications are quite different from those of asymmetric information. For example, adverse selection based on asymmetric information might lead to a policy recommendation of mandatory annuitization at a common price for all, while adverse selection based on correlations between income or wealth-driven demand for annuities and longevity might lead to a policy recommendation that insurance companies be allowed to place people according to their income or wealth into different categories for which differing prices would be charged because of different risks involved.

${ }^{16}$ Singapore has no formal first pillar, although it does have subsidized means-tested public services. The difference between annuitant and population MRS in Singapore should be viewed with some caution, as mortality data for annuitants in Singapore are "borrowed" from old data in the UK; it is possible that these data substantially understate true life expectancy. The UK has a basic benefit that is about $16 \%$ of the average wage, supplemented by means-tested benefits. In comparing our numbers with those in Finkelstein and Poterba, who have access to data that enable them to separate out the voluntary and compulsory parts of the market, it is clear that the relatively low selection in the UK in our data comes exclusively from the compulsory part. A comparison of the life 
expectancy and MWR for the level-SPIA for the population (both) and for annuitants in our paper and theirs, is shown in the following table:

\begin{tabular}{|l|c|c|}
\hline & Life expectancy & MWR-level SPIA \\
\hline Population cohort (both) & 80.4 & 91.2 \\
\hline Annuitant cohort (James \& Song) & 82.1 & 98.3 \\
\hline Compulsory annuitant cohort-FP & 81.5 & 96.2 \\
\hline Voluntary annuitant cohort-FP & 82.8 & 100.9 \\
\hline
\end{tabular}

${ }^{17}$ Using the Gini coefficient as a rough measure of inequality, the Gini is 56.6 in Chile, 40.8 in the US, varies between 33 and 36 in the other countries, but is only 31.5 in Canada. If selection stems in part from income inequality that is correlated with disparities in longevity, we would expect the Gini to be correlated with the load differentials between annuitants and the average population member, ceteris paribus.

18 In Switzerland, Pillars I and II in the mandatory system provide a replacement rate of about $60 \%$ to most workers. Only very high earners get a lower replacement rate and demand annuities in Pillar III to top it up.

${ }^{19}$ For the $10 \mathrm{YG}$ annuity, the first ten years of payouts are the same for long and short-lived individuals and for joint annuities two lifetimes are involved, whose longevities may not be perfectly correlated. Thus the gap between MWR of annuitants and population would be smaller, even if the annuitant group was the same for all products. Of course, the annuitant group may not be the same. We would expect that lower longevity workers would be attracted to the $10 \mathrm{YG}$ or joint products, and insurance companies would therefore price the level SPIA on the basis of a higher longevity annuitant group. Unfortunately we do not have data on differential mortality by annuity product. Finkelstein and Poterba 2000 has such data for a large annuity company in the UK and find mortality differentials by product.

${ }^{20}$ Possibly in a broader sample of countries with wider divergence in life expectancy at 65 , expected mortality rates would influence monthly payouts. However, the greater divergence could only come on the downside and countries with much lower life expectancy are unlikely to have the financial instruments needed to support annuity markets.

21 Swiss life insurance companies also have tables with still lower mortality rates, which they use to build in an explicit safety factor. We used the rates without the explicit safety factor, which nevertheless are quite low by international standards - suggesting that perhaps an implicit safety factor has been built in, compared with other countries.

22 Sources for these numbers are: Hug 1999, Kim and Sharp 1999, annual reports of Swiss life Rentenanstalt and Metlife, LIMRA 1998, correspondence and interviews with insurance company executives Mark Hug (Equitable), Alex Sheitlin (Metlife), Michael Koller and Fred Siegrist (Swiss life), Tim Pfeiffer (insurance industry consultant), Shane Chalke (CEO of AnnuityNet, a company that shapes and sells annuity products) and others.

${ }^{23}$ Data are not available for Israel but according to our informants the picture there is quite different: investments are heavily concentrated in government bonds due to the absence of 
alternative financial instruments. This may help account for the relatively low MWR in Israel; costs must be covered explicitly through the load since they cannot be covered implicitly through the spread.

${ }^{24}$ Real Returns over Risk-Free Rate by Asset Class, 1967-95

\begin{tabular}{|l|l|l|l|l|l|}
\hline Country & $\begin{array}{l}\text { Corporate } \\
\text { Bonds }\end{array}$ & $\begin{array}{l}\text { Loans \& } \\
\text { Mortgages }\end{array}$ & Equities & $\begin{array}{l}\text { Real Estate } \\
\text { and Land }\end{array}$ & Liquid Assets \\
\hline US & 0.5 & 3.05 & 5.0 & 4.4 & 0.8 \\
\hline Canada & 1.3 & 2.85 & 3.0 & 7.4 & 0.7 \\
\hline UK & 1.1 & 1.2 & 7.3 & 0.5 & 1.1 \\
\hline Switzerland & 0.4 & 2.2 & 7.8 & 1.7 & 1.3 \\
\hline Australia & 2.0 & 4.2 & 8.4 & 4.5 & 1.9 \\
\hline Average & 1.0 & 2.4 & 6.3 & 4.8 & 0.1 \\
\hline
\end{tabular}

Source: Davis and Steil (2000).

Note: Loans and Mortgages returns are weighted returns on "loans" and "mortgages" (50\% and 50\%).

Average returns calculation is based on 12 OECD countries.

${ }^{25}$ Both of these countries engage in inter-temporal smoothing of annuity prices - prices do not change nearly as often as in the US, UK or Canada. This was possible because of the relatively non-competitive nature of the market in these countries. At the point when we measured MWR, the yield curve was very steep in these two countries. Today they are somewhat less steep. Discounting the same payouts at today's interest rates would yield a somewhat lower MRW. In countries where payouts do not adjust rapidly, calculated MWR's should be averaged over a longer time period since they are very sensitive to the date at which a snapshot picture is taken. It was not feasible for us to get the data to take the average over a long time period in these countries.

${ }^{26}$ This became a legal issue in the case of Equitable in the UK. Some annuity customers were in participating policies whose payouts were partially at the discretion of the company in the form of annual bonuses, while for others a guaranteed minimum buttressed the bonuses. When interest rates fell precipitously in the 1990's, the company had trouble honoring these guarantees that were based on much higher interest rates. First it tried to cut the bonuses of its guaranteed customers, but a legal battle prevented Equitable from doing this, as a violation of the terms of the guarantee. Instead, everyone's bonus was cut. Equitable tried to sell its business, but other companies have refused to take on this liability. Equitable has now been forced to stop taking in new business. The minority with guarantees has been protected at the expense of the majority of customers without these guarantees. This illustrates the "safety" provided by guaranteed annuities, the crosssubsidization by other customers, and the need for full disclosure of information about liabilities and careful regulation, especially when risk-sharing arrangements are involved. (Plender 2000; The Economist. 2000, pp. 85-86). 
Our papers can be downloaded at:

http://cerp.unito.it

CeRP Working Paper Series:

\begin{tabular}{|c|c|c|}
\hline $\mathrm{N}^{\circ} 1 / 00$ & Guido Menzio & Opting Out of Social Security over the Life Cycle \\
\hline $\mathrm{N}^{\circ} 2 / 00$ & $\begin{array}{l}\text { Pier Marco Ferraresi } \\
\text { Elsa Fornero }\end{array}$ & $\begin{array}{l}\text { Social Security Transition in Italy: Costs, Distorsions } \\
\text { and (some) Possible Correction }\end{array}$ \\
\hline $\mathrm{N}^{\circ} 3 / 00$ & $\begin{array}{l}\text { Emanuele Baldacci } \\
\text { Luca Inglese }\end{array}$ & $\begin{array}{l}\text { Le caratteristiche socio economiche dei pensionati in } \\
\text { Italia. Analisi della distribuzione dei redditi da } \\
\text { pensione (only available in the Italian version) }\end{array}$ \\
\hline $\mathrm{N}^{\circ} 4 / 01$ & Peter Diamond & Towards an Optimal Social Security Design \\
\hline $\mathrm{N}^{\circ} 5 / 01$ & Vincenzo Andrietti & $\begin{array}{l}\text { Occupational Pensions and Interfirm Job Mobility in } \\
\text { the European Union. Evidence from the ECHP Survey }\end{array}$ \\
\hline$N^{\circ} 6 / 01$ & Flavia Coda Moscarola & $\begin{array}{l}\text { The Effects of Immigration Inflows on the } \\
\text { Sustainability of the Italian Welfare State }\end{array}$ \\
\hline $\mathrm{N}^{\circ} 7 / 01$ & Margherita Borella & $\begin{array}{l}\text { The Error Structure of Earnings: an Analysis on } \\
\text { Italian Longitudinal Data }\end{array}$ \\
\hline $\mathrm{N}^{\circ} 8 / 01$ & Margherita Borella & $\begin{array}{l}\text { Social Security Systems and the Distribution of } \\
\text { Income: an Application to the Italian Case }\end{array}$ \\
\hline $\mathrm{N}^{\circ} 9 / 01$ & Hans Blommestein & $\begin{array}{l}\text { Ageing, Pension Reform, and Financial Market } \\
\text { Implications in the OECD Area }\end{array}$ \\
\hline $\mathrm{N}^{\circ} 10 / 01$ & $\begin{array}{l}\text { Vincenzo Andrietti and } \\
\text { Vincent Hildebrand }\end{array}$ & $\begin{array}{l}\text { Pension Portability and Labour Mobility in the United } \\
\text { States. New Evidence from the SIPP Data }\end{array}$ \\
\hline $\mathrm{N}^{\circ} 11 / 01$ & $\begin{array}{l}\text { Mara Faccio and } \\
\text { Ameziane Lasfer }\end{array}$ & $\begin{array}{l}\text { Institutional Shareholders and Corporate Governance: } \\
\text { The Case of UK Pension Funds }\end{array}$ \\
\hline $\mathrm{N}^{\circ} 12 / 01$ & Roberta Romano & $\begin{array}{l}\text { Less is More: Making Shareholder Activism a } \\
\text { Valuable Mechanism of Corporate Governance }\end{array}$ \\
\hline $\mathrm{N}^{\circ} 13 / 01$ & Michela Scatigna & $\begin{array}{l}\text { Institutional Investors, Corporate Governance and } \\
\text { Pension Funds }\end{array}$ \\
\hline
\end{tabular}


$\mathrm{N}^{\circ} 14 / 01$ Thomas H. Noe

$\mathrm{N}^{\circ} 15 / 01 \quad$ Estelle James

$\mathrm{N}^{\circ} 16 / 01 \quad$ Estelle James and Xue Song
Investor Activism and Financial Market Structure

How Can China Solve ist Old Age Security Problem? The Interaction Between Pension, SOE and Financial Market Reform

Annuities Markets Around the World: Money's Worth and Risk Intermediation 